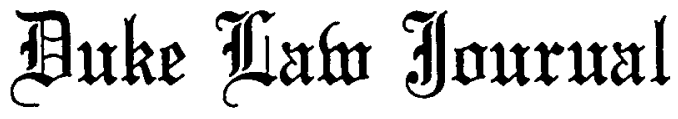

\begin{tabular}{llr}
\hline VOLUME 1982 & NOVEMBER & NUMBER 5 \\
\hline
\end{tabular}

\section{ZONING FOR DIRECT SOCIAL CONTROL}

\author{
J. GREGORY RICHARDS*
}

Contents

I. INTRODUCTION................................ 762

II. ZONING For Direct Soclal Control: The FAMILY .... 767

A. Historical Development of Single-Family Ordinances .. 767

B. Purported Goals of Zoning for the Traditional Family . 773

C. Enter the Courts: Constitutional Issues and Substantive

Review ....................................... 781

1. Due Process............................... 782

2. Equal Protection ........................... 786

3. The "Functional Family" ..................... 790

4. Mitigating Factors: The "Escape Hatches" ....... 793

D. The Avoidance of Abuses and the Balancing

of Values .................................. 796

III. ZONING For DiRECT SOCIAL CONTROL: AgE

RESTRICTIONS.................................. 799

A. Development of Age-Restrictive Zoning .............. 799

B. Purported Goals of Age-Restrictive Zoning .......... 803

C. Substantive Review of Age-Restrictive Zoning ......... 807

1. The Enabling Acts ........................ 807

2. Equal Protection: Weymouth Township ........ 809

* This article is a condensation of a thesis submitted to The University of Michigan Law School in partial fulfillment of the requirements for the degree of Doctor of the Science of Law (S.J.D.). A copy of the unabridged thesis is on file in the library of The University of Michigan Law School. Research for this article was made possible through the generosity of a William W. Cook Fellowship. Funding was also provided by the Social Sciences and Humamities Research Council of Canada. I would like to take this opportunity to thank Professors Joseph L. Sax and Sallyanne Payton, who sat on my thesis committee and reviewed an earlier draft of this work. Special thanks are due to Professor Roger A. Cunningham, uny thesis supervisor, who endured many drafts. Of course, responsibility for any shortcoming in the work remains with the author. 
D. The Non-Elderly Who Wish to Exclude Children:

"Adult-Only" Developments ..................... 815

E. The Potential for Abuse and Methods of Avoiding It ... 818

1. The Potential for Abuse ....................... 818

2. Fact Bases ............................... 818

3. Comprehensive Planning..................... 821

4. Comprehensive Plan for Balanced Housing Stock and Alternative Sites ........................... 823

5. Presumptions and Burdens of Proof ............. 825

IV. ZONING FOR DIRECT SOCIAL CONTROL: INDIGENTS, StUdents, Racial Minorities, AND BEYoND.......... 828

A. Inclusionary Zoning ........................ 828

B. Zoning with Respect to Students................. 833

C. "Benign" Racial Zoning and Other Experiments...... 835

V. Conclusion..................................... 840

\section{INTRODUCTION}

Traditionally, people have thought of zoning as a means of controlling physical aspects of the urban environment. Indeed, over the years zoning has frequently been viewed as a method of "nuisance control"- the device that protects a homeowner from having a glue factory, or some other noxious use, locate next door. There is a good deal of justification for this widely held view.

Although a number of local regulatory efforts around the turn of the century resembled zoning, the building zone resolution of New York City, passed in 1916, "constituted the first comprehensive zoning of height, area, and use $\mathrm{m}$ this country." 1 The individuals who brought comprehensive zoning to New York City were deeply concerned with controlling the negative externalities accompanying various urban land uses. In particular, the skyscraper, with its propensity to make "dark canyons of narrow streets," 2 was identified as an architectural villain that could create fire hazards, foster crowding and panic should a catastrophe occur, and threaten public health by shutting out hight, thus contributimg to eyestram and the spread of tuberculosis. ${ }^{3}$

The zoning pioneers also sought the stabilization of neighborhoods with a view to protection of property values. In making the case for zoning, they wrote of apartments and retail uses mvading residential districts while, im turn, "bright busmess streets would be mvaded by

1. E. BASSETT, ZONING 23 (1940 ed.).

2. Id. at 24.

3. See S. TOLI, ZoNED AMERICAN 153-54 (1969). 
factories." 4 With its apparent ability to separate incompatible land uses, zoning appeared a good means of protecting property values.

Courts also thought of zoning in terms of its contribution to the improvennent of the physical environinent during these early years, as Village of Euclid v. Ambler Realty Co. ${ }^{5}$ illustrates. In Euclid the Supreme Court considered the constitutional validity of coinprehensive zoning for the first time. In arriving at its decision the Court looked to the common law of nuisance, not to delimit the boundaries of the zoning power, "but for the helpful aid of its analogies."6 The Justices identified the most contentious aspect of the Euclid scheme-the creation of a residential classification which excluded not only busmess and industrial uses, but apartment buildings as well. In upholding this restriction, the Court described in terms of physical impact how the presence of a multiple-family structure could lead to a deterioration in developinental quality:

[T] he coming of one apartment house is followed by others, interfering by their height and bulk with the free circulation of air and monopolizing the rays of the sun[, . . . bringing . . . increased traffic and business, . . . depriving children of the privilege of quiet and open spaces for play, . . . until, finally, the residential character of the neighborhood and its desirability as a place of detached residences are utterly destroyed. Under these circumstances, apartment houses, which in a different environment would not only be entirely unobjectionable but highly desirable, come very near to being nuisances. ${ }^{7}$

Not ouly did the judiciary usually think of zoning as a means of orderimg the urban environinent to reduce negative externahties; some courts took the position that zoning ordinances should not regulate anything but the physical aspects of land use. ${ }^{8}$ Nevertheless, over the years both courts and commentators have noted that, like it or not, land use restrictions apparently aimed at physical concerns alone can have profound socioeconomic implications.

4. E. BASSETT, ZoNING 315-16 (Nat'l Municipal League Tech. Pamphlet Series No. 5, rev. 1922).

5. 272 U.S. 365 (1926).

6. Id. at 387 .

7. Id. at 394-95.

8. For instance, Justice Frederick Hall of the Supreme Court of New Jersey, in a dissent which has simce become famous for other reasons, stated that zoning is "land use control by physical planning to bring about physical results" and "is not a device to be used to accomplish any and all purportedly desirable social results." Vickers v. Township Comm., 37 N.J. 232, 261, 181 A.2d 129, 145 (1962) (emphasis in original), appeal dismissed and cert. denied, 371 U.S. 233 (1963). Similar opinious have appeared in other cases. See, e.g., Central Manageinent Co. v. Town Bd., 47 Misc. 2d 385, 262 N.Y.S.2d 728, affd mem., 24 A.D.2d 881, 264 N.Y.S.2d 1011 (1965); Board of Supervisors v. DeGroff Enters., 214 Va. 235, 238, 198 S.E.2d 600, 602 (1973). 
The capacity for local ordinances dealing exclusively with physical standards to dictate, albeit indirectly, who may hive where has appeared nost clearly in "exclusionary zoning." Such land use controls are "those which interfere seriously with the availability of housing for low- and moderate-income people in areas where such housing is much needed." By manipulating restrictions on inatters such as lot size, lot width, buildmg size, or the number of bedrooms in multiple-family umits, or by excluding mobile hoines or inultiple-family structures, a mumicipality can make housing within its borders too expensive for low- and moderate-income groups. Exclusionary zoning has served goals that courts ${ }^{10}$ and commentators ${ }^{11}$ have identified as improper. For instance, zoning ordinances have separated housing for workingclass families from industrial job opportunities, ${ }^{12}$ and barred racial minorities from communities to the extent that a greater proportion of these groups are forced into the lower income levels. ${ }^{13}$

Even in the earhest years of the imstitution some people expressed concern that zoning could effect profound socioeconomic, includimg exclusionary, results. The district court's opimon in Euclid provides an apt exaniple: Judge Westenhaver found it a "plain truth" that the vil-

9. 2 N. Williams, American Land Planning Law $\$ 64.01$, at 666 (1974).

10. See, e.g., Village of Arlington Heights v. Metropolitan Hous. Dev. Corp., 429 U.S. 252 (1977); Metropolitan Hous. Dev. Corp. v. Village of Arlington Heights, 558 F.2d 1283 (7th Cir. 1977), cert. denied, 434 U.S. 1025 (1978); United States v. City of Black Jack, 508 F.2d 1179 (8th Cir. 1974), cert. denied, 422 U.S. 1042 (1975); Pascack Ass'n v. Mayor of Washington, 74 N.J. 470, 379 A.2d 6 (1977); Oakwood at Madison, Inc. v. Township of Madison, 72 N.J. 481, 371 A.2d 1192 (1977); Southem Burlington County NAACP v. Township of Mount Laurel, 67 N.J. 151, 336 A.2d 713, appeal dismissed and cert. denied, 423 U.S. 808 (1975); Surrick v. Zoning Hearing Bd., 476 Pa. 182, 382 A.2d 105 (1977); Concord Township Appeal, 439 Pa. 466, 268 A.2d 765 (1970); Girsh Appeal, 437 Pa. 237, 263 A.2d 395 (1970); National Land \& Inv. Co. v. Easttown Township Bd. of Adjustment, $419 \mathrm{~Pa} .504,215$ A.2d 597 (1965).

11. See, e.g., R. BaBcock \& F. Bosselman, Exclusionary Zoning: LAND USE RegulaTION AND HousING IN THE 1970s 3-44 (1973); 2 N. WILLLAMS, supra note 9, chs. 62-65; 3 id. ch. 66; Bigham \& Bostick, Exclusionary Zoning Practices: An Examination of the Current Controversy, 25 V AND. L. Rev. 1111 (1972); Haar, Zoning for Minimum Standards: The Wayne Township Case, 66 HaRv. L. Rev. 1051 (1953); Sager, Tight Little Islands: Exclusionary Zoning, Equal Protection, and the Indigent, 21 STAN. L. REv. 767 (1969); Williams \& Norinan, Exclusionary Land Use Controls: The Case of North-Eastern New Jersey, 22 SyRACuSE L. REV. 475 (1971); Developments in the Law-Zoning, 91 HaRv. L. REv. 1427, 1618-1708 (1978).

12. See Ellickson, Alternatives to Zoning: Covenants, Nuisance Rules, and Fines as Land Use Controls, 40 U. ChI. L. Rev. 681, 704 (1973); see also M. DANielson, The Politics of ExclUSION 23-24 (1976).

13. See D. Hagman, Urban Planning and Land Development Control Law $\$ 243$ n. 6 (1975); 2 N. WILlIAMS, supra note 9, § 59.07, at 585; Aloi, Goldberg, \& White, Racial and Economic Segregation by Zoning: Death Knell for Home Rule?, 1 U. ToL. L. REv. 65, 74-79 (1969); Branfman, Cohen \& Trubek, Measuring the Invisible Wall: Land Use Controls and the Residential Patterns of the Poor, 82 YALE L.J. 483, 503-06 (1973); Williams, Planning Law and Democratic Living, 20 LAW \& CONTEMP. PROBS. 317, 330 (1955) ("Economic segregation is not only the easiest but also the most effective form of racial and ethnic segregation. . . ."). 
lage's ordinance sought to place the affected land in a "strait-jacket" and concluded that "[i]n the last analysis, the result to be accoinplislied is to classify the population and segregate thein according to their income or situation in life." 14 In an article publislred in 1920 entitled Unwalled Towns, Bruno Lasker argued that zoning "inevitably increases the separation of the classes." 15

Today most would admit that residential zoning does, indeed, determine to some extent the type of person who lives in a particular area, even if, unlike Westenhaver and Lasker, they may not consider this state of affairs necessarily bad. ${ }^{16}$ New Jersey's highest court provided an illustration of the modern view in Taxpayers Association v. Weymouth Township, ${ }^{17}$ observing that "as a conceptual matter regulation of land use cannot be precisely dissociated from regulation of land users." 18 Tlus, generally speaking, a zoning ordinance that in its operation displays a socioeconomic purpose or effect will not disturb the judiciary merely because it does not deal exclusively with physical characteristics.

Conventional residential zoning ordinances regulate tangible elements of the urban environinent, identifying the users or potential users of a given parcel of land in only an indirect manner. But municipalities can also explicitly identify land users or potential land users in zoning ordinances, and in this manner exercise social control directly. In doing so, localities have "zoned for direct social control." This article addresses this sort of land use regulation. ${ }^{19}$ As a useful starting point, this article constructs a definition of zoning for direct social control:

A zoning ordinance is used for direct social control when land users are authorized to live in a residential district, or potential land users are excluded from the same, on the basis of relatively immutable personal characteristics that are explicitly identified in the ordinance.

14. Ambler Realty Co. v. Village of Euclid, 297 F. 307, 316 (N.D. Ohio 1924), rev'd, 272 U.S. 365 (1926).

15. 43 The SURVEY 675, 676 (Mar. 6, 1920).

16. See, e.g., Advisory CoMmitTeE to the Dep't of Housing and URban DevelopMENT, National ACADEMy of ScienCes-National ACADEMY of Engineering, Freedom of Choice in Housing 31 (1972), quoted in E. Bergman, Eliminating Exclusionary Zoning: ReCONCILING WorkPLACE AND Residence IN SUburban AReAs 15 (1974) ("The nature of zoning is such that it is difficult to disentangle its control over plysical development per se, its influence over the economic status of prospective residents, and its use to discriminate against specific ethnic or racial groups."); C. Perin, Everything in ITs PLACE 3 (1977); Gans, Social and Physical Planning for the Elimination of Urban Poverty, 1963 WASH. U.L.Q. 2, 16.

17. 71 N.J. 249, 364 A.2d 1016 (1976), appeal dismissed and cert. denied, 430 U.S. 977 (1977).

18. Id. at 277,364 A.2d at 1031 .

19. Many courts and commentators have cousidered exclusionary zoning which exercises social control in an indirect way. See, e.g., authorities cited supra notes 10-11. 
There are several reasons for examining the use of zoning as a direct social control. First, such zoning raises the clash between the police power, the basis of all zoning restrictions, and certain constitutional protections in a most interesting way, and lielps to test the boundaries of each. An inquiry into zoning of this sort also helps to determine the regulatory capacity of enabling legislation and other devices that delegate the zoning power from the state legislatures to municipalities. Zoning for direct social control also illustrates the use of zoning to further sophisticated inodern regulatory goals. Fimally, in the past, with one major exception, ${ }^{20}$ few sucli regulations were promulgated; currently they appear to be unuch more prevalent and are einployed to serve increasimgly diversified ends.

One potential end of this type of zoning is racial segregation.21 Yet the segregation ordinance is the easy case: zoning with respect to race for purposes of segregation ${ }^{22}$ founders on clearly overriding constitutional protections. But what of other, less obviously unfair, measures effecting direct social control? For instance, a great number of municipalities have enacted ordinances that, with certain exceptions, authorize only individuals related by blood, inarriage, or adoption-in other words, a traditional family-to live in a dwelling unit in a partic-

20. The exception is racial zoning for segregation. See infra note 21 .

21. Possibly the first zoning ordinance aimed at racial segregation was the "Binghain Ordinance," adopted in San Francisco at the end of the nineteenth century, which rcquired the city's Chinese population to abandon their residences and businesses and quit the city and county of San Francisco or, in the alternative, move to a designated area within the municipality. See generally In re Lee Sing, 43 F. Supp. 359 (N.D. Cal. 1890) (ordinance invalidated). Most local segregation laws tried to separate whites from blacks. Early attempts preceded the development of comprehensive zoning and were often called "segregation ordinances." See generally Benson, Segregation Ordinances, 1 VA. L. REG. (n.s.) 330 (1915); Note, Constitutionality of Residential Segregation Ordinances, 41 KY. L.J. 250 (1952). Later efforts were incorporated into coinprehensive zoning restrictions. See, e.g., Monk v. City of Birmingham, 87 F. Supp. 538 (N.D. Ala. 1949!, affd, 185 F.2d 859 (5th Cir. 1950), cert. denied, 341 U.S. 940 (1951).

Apparently the first segregation ordinance was adopted in Baltimore in 1911, Baltimore, Md., Ordinance 692 (May 15, 1911), but it was a Louisville, Kentucky, ordinance that came before the Supreme Court in Buchanan v. Warley, 245 U.S. 60 (1917). The Buchanan ordinance was typical of many: it inade it unlawful for any black to nove into and occupy a house in a block where a majority of dwellings were occupied by whites. After reviewing the history of the fourteenth amendment, its treatment in the case law, and the legislative provisions enacted to implement it, the Court concluded that the state could not lawfully disqualify a man from acquiring property solely because of color, or prevent a man from selling his property solely because of the buyer's color. Buchanan clearly established the invalidity of segregation ordinances, and subsequent atteinpts by recalcitrant municipalities to adopt this type of regulation were struck down. See, e.g., Bowen v. City of Atlanta, 159 Ga. 145, 125 S.E. 199 (1924); Tyler v. Harmon, 160 La. 943, 107 So. 704 (1926), rev'd per curiam, 273 U.S. 668 (1927); Jackson v. State, 132 Md. 311 , 103 A. 910 (1918); Clinard v. City of Winston-Salem, 217 N.C. 119, 6 S.E.2d 867 (1940); Irvine v. City of Clifton Forge, 124 Va. 781, 97 S.E. 310 (1918).

22. Racial zoning for the purpose of promoting integration is discussed infra in Part IV. 
ular residential district. In other cases, local governments have adopted age-restrictive ordinances that permit only the elderly to live in a defined zone. These ordinances plainly aim at goals other than the traditional objectives, such as providing more liglit and air, that characterized early zoning efforts. At the same time, these new ordinances do not seek to further residential preferences as obviously base as segregation. Whether the law can accommodate these experiments is a question worth exploring.

Part Il of this article examines ordinances that permit only traditional families to hive in a dwelling area. Part III discusses age-restrictive zoning. Some other fonns of zoning for direct social control are identified in Part IV. Each of these parts traces the historical development of the type of zoning discussed, indicates the purported goals of those restrictions, and outlines some of the constitutional implications of such ordinances. Each part also suggests some safeguards agaimst potential abuses of land use restrictions of this kind. Finally, addressed in each section, and inost fully explored in Part III, are several tests that courts should apply in reviewing these newest developinents in zoning, to insure that the competing values they einbody receive proper attention.

\section{Zoning for Direct Social Control: The Family}

\section{A. Historical Development of Single-Family Ordinances.}

"Promotion of the single-family lome . . . is deened good public policy in America," 23 wrote Alfred Bettman in 1924. Fostered by this sentiment, zoning spread swiftly, ${ }^{24}$ particularly in suburban communities. ${ }^{25}$

The origimal New York City building zone resolution did not establish an exclusive single-family home area; it merely created a district where new dwellings could cover no more than thirty percent of the lot. ${ }^{26}$ The resolution's backers thought that treating private detaclied

23. Bettman, Constitutionality of Zoning, 37 HARv. L. REv. 834, 839-40 (1924).

24. See R. Babcock, The Zoning Game 115 (1966); B. Siegan, Land Use Without ZonING 49 (1972); Ellickson, supra note 12, at 629 ("Although a few major cities had earlier made modest attempts to control land uses, the precedent of the New York City ordinance triggered the rapid spread of zoning, apparently because of its political appeal as a device to protect the value of single-family homes."); see also E. BASSETT, supra note 1, at 64; J. DELAFONS, LAND-UsE CONtrols in the United States 26 (1962); National Commission on Urban Problems, BuildING THE AMERICAN CTTY 204 (1969).

25. See S. Toll, supra note 3, at 193 ("The suburbs were among the first municipalities in the nation to enact zoning. During the twenties they were prime contributors to the extraordinary spread of the institution.").

26. E. BASSETT, supra note 4, at 323. 
residences as a separate use would be a "hazardous course" because courts might question whether traditional police power considerations of health and safety could justify a differentiation between one-family and two-family dwellings.27 Court decisions soon proved, however, that no such hazard existed. The United Statcs Supreme Court allowed the exclusion of apartinent buildings from residential districts, ${ }^{28}$ and a Massachusetts court decided that two-family dwellings could be validly separated froin single-family hoines. ${ }^{29}$ Thus, by the mid-1920s the legitimacy of exclusive single-family districts was settled; the next important question became how, if at all, a given ordinance defined the term "family" for purposes of determining who could live im these districts. ${ }^{30}$

In the early years of zoning, a significant number of ordmances simply left the word family undefined, ${ }^{31}$ and soine modern ordinances continue to mclude no definitional provision..$^{32}$ A good deal of hitigation naturally resulted: hoineowners or occupants and zoning enforceinent authorities often disagree on exactly what "single-family" means. ${ }^{33}$ Ultimately the courts can decide, but the obvious problem with this type of ordinance is the uncertamty it creates. ${ }^{34}$

Even in the earliest days of zoning inany mumcipalities were not willing to leave so much to chance and therefore included some defini-

27. See id. at 323-24.

28. See Village of Euclid v. Ambler Realty Co., 272 U.S. 365, 394-95 (1926).

29. Brett v. Building Comm'r, 250 Mass. 73, 145 N.E. 269 (1924).

30. Of course, the definition of "family" could also affect the occupants of two-family and other multiple-family dwellings. It appears, however, that the definition of "family" has been contested almost exclusively in relation to single-family dwelling districts. Furthermore, restrietions on dwelling type were invariably accompanied by regulations concerning physical characteristics such as lot size, area of permissible coverage, building leight, and so on. Thus, the type of area restriction enployed in the original New York City building zone resolution was not abandoned; it was merely supplennented by regulations segregating building types.

31. See, e.g., Baltimore, MD., CoDe art. 49, § 1 (1928); Birmingham, Ala., General Code Ordinance 1101-C, art. I, \& 1 (1930).

32. See, e.g., Brady v. Superior Court, 200 Cal. App. 2d 69, 77-82, 19 Cal. Rptr. 242, 247-49 (1962) (discussing Atherton Ord. 146 \& 22-5); Region 10 Client Management, Inc. v. Town of Hampstead, 120 N.H. 885, 887, 424 A.2d 207, 208-09 (1980) (discussimg Hampstead Zoning Ordinance); Carroll v. Washington Township, 63 Ohio St. 2d 249, 251, 408 N.E.2d 191, 193 (1980).

33. See, e.g., Brady v. Superior Court, 200 Cal. App. 2d 69, 71-72, 19 Cal. Rptr. 242, 243-44 (1962); Planning \& Zoning Comm'n v. Synanon Found., 153 Conn. 305, 311, 216 A.2d 442, 444 (1966); Village of Riverside v. Reagan, 270 Ill. App. 355, 365-66 (1933); Pettis v. Alpha Alpha Chapter of Phi Beta Pi, 115 Neb. 525, 529, 213 N.W. 835, 837 (1927); Sullivan v. Anglo-American Inv. Trust, Inc., 89 N.H. 112, 115, 193 A. 225, 227 (1937); Village of Quogue v. Ladd, 40 A.D.2d $859,859,337$ N.Y.S.2d 868, 869 (1972); City of Schenectady v. Alumni Ass'n of Union Chapter, Delta Chi Fraternity, Inc., 5 A.D.2d 14, 15, 168 N.Y.S.2d 754, 755 (1957); Town of Henrietta v. Fairchild, 53 Misc. 2d 862, 279 N.Y.S.2d 992 (Sup. Ct. 1967).

34. One commentator has concluded that in general "the courts have approached these cases on a praginatic, ad hoc basis." Note, Excluding the Commune from Suburbia: The Use of Zoning for Social Control, 23 HASTINGS L.J. 1459, 1465 (1972). 
tion of family in their zoning restrictions. One formulation defined family as a "single housekeeping unit," and nany early restrictions incorporated this definition ${ }^{35}$ or some variation thereof, including the zoning regulation at issue in the Euclid case. ${ }^{36}$ But whether the "single housekeeping unit" formulation injected any certainty into the systein is open to question. This type of ordinance has also given rise to a significant amount of litigation, ${ }^{37}$ and courts have often interpreted the formulation in ways that frustrate its basic objective of limiting the occupation of homes to relatively permanent and stable groups. ${ }^{38}$

Many municipalities sought even more certain control over the composition of domestic units occupymg dwellings in residential areas. They developed provisions describing a family in terms of the biological and legal interrelationships of its menbers, thus restricting a residential area to what might be variously called "legal," "biological," "traditional," or "conventional" families. A typical example might define "family" as follows:

One or more persons related by blood, adoption, or marriage, living and cooking together as a single housekeeping unit, exclusive of household servants. A number of persons but not exceeding two (2) living and cooking together as a single housekeeping unit though not

35. It seems that even before 1920, a Newark, New Jersey ordinance included such a provision. See Citizens' Zone Plan Conference, Chicago 20 (1920) (report of proceedings, Dec. 16-17, 1919).

36. See J. Metzenbaum, The Law of Zoning 338 (1930) (reproducing the Village of Euclid ordimance that was upheld by the Supreme Court); see also, e.g., AlEXANDRIA, VA., CODE $§ 35-$ 1(33) (1953); Atlanta, GA., Code \$ 93-202(k) (1942); Chicago, Ill., Revised Code \$ 1860(i) (1931); Cleveland, Ohio, Code § 1281-14 (1924); $c$. Philadelphia, Pa., Code $\$ 14-102(11)$ (1956) ("Family. A person or a group of persons living together."). The widespread use of the single housekeeping unit formulation may have resulted froin its use by leading commentators on zoning, see, e.g., E. BASSETr, supra note 1, at 189, and by its use in various model ordinances, see, e.g., New York Dep't of Commerce, Zoning in New York State: A Guide to the Preparation of Zoning Ordinances 45-46 (rev, ed. 1958).

37. See, e.g., Neptune Park Ass'n v. Steinberg, 138 Conn. 357, 84 A.2d 687 (1951); Oliver v. Zoning Comm'n, 31 Conn. Supp. 197, 326 A.2d 841 (C.P. 1974); Carroll v. City of Miami Beach, 198 So. 2d 643 (Fla. Dist. Ct. App. 1967); Harmon v. City of Peoria, 373 Ill. 594, 27 N.E.2d 525 (1940); Baddour v. City of Long Beach, 279 N.Y. 167, 18 N.E.2d 18, 7 N.Y.S.2d 167 (1938), reh'g denied, 279 N.Y. 794, 19 N.E.2d 90, 7 N.Y.S.2d 794, appeal dismissed, 308 U.S. 503 (1939); Carroll v. Arlington County, 186 Va. 575, 44 S.E.2d 6 (1947); Missionaries of Our Lady of La Salette v. Village of Whitefish Bay, 267 Wis. 609,66 N.W.2d 627 (1954); see also cases cited infra note 38.

38. For example, in one case a single housekeeping unit restriction was held not to exclude a college sorority. See City of Syracuse v. Snow, 123 Misc. 568, 205 N.Y.S. 785 (Sup. Ct. 1924). In the majority of cases, however, it would be fair to say that the "single housekeeping unit" formulation has proved effective in fratermity-sorority cases. See, e.g., Cassidy v. Triebel, 337 Ill. App. 117, 85 N.E.2d 461 (1949); Theta Kappa, Inc. v. City of Terre Haute, 141 Ind. App. 165, 226 N.E.2d 907, reh'g denied, 141 Ind. App. 165, 228 N.E.2d 34 (1967). However, courts have held that twenty nurses can be a simgle housekeeping unit, see Robertson v. Western Baptist Hosp., 267 S.W.2d.395 (Ky. Ct. App. 1954), as can sixty college students, see In re Laporte, 2 A.D.2d 710, 152 N.Y.S.2d 916 (1956). 
related by blood, adoption or marriage shall be deemed to constitute a family. ${ }^{39}$

The requireinent that the individuals comprise a single housekeeping unit in addition to the requireinent of legal or biological relatedness almost invariably appears in these definitions. So the traditional-fan1ily definition simply adds restrictions to the simgle housekeeping umit formulation. An exception permitting soune families of unrelated individuals is another element common in these definitions, though the nuniber of unrelated persons that will be deeined to constitute a family in a given ordinance varies widely..$^{40} \mathrm{~A}$ few ordinances inake no such exception..$^{41}$ In other ordimances, some "other doinestic bond" inay satisfy the requirenent of relatedness in addition to the usual ties of blood, inarriage, or adoption. ${ }^{42}$ Resort commumities have introduced requirenents of permanent rather than seasonal occupancies, ${ }^{43}$ other definitions require that the related group live under "one head."44

39. Village of Belle Terre v. Boraas, 416 U.S. 1, 2 (1974) (quoting Belle Terre, Long Island Ordinance).

40. The number is often five, see, eg., City of Santa Barbara v. Adamson, $27 \mathrm{Cal} .3 \mathrm{~d} 123$, 127, 610 P.2d 436, 437, 164 Cal. Rptr. 539, 542 (1980) (en banc); Douglass v. City of Spokane, 25 Wash. App. 823, 609 P.2d 979 (1980) (discussing Spokane Zoning Ord. 110.060), but it can range as high as ten, see, e.g., State ex rel. Ellis v. Liddle, 520 S.W.2d 644, 647 (Mo. Ct. App. 1975) (discussing Meryville, Mo. Zoning Ord. 3142). Another common provision in these types of ordinances exempts domestic servants from the relatedness requirements. See, e.g., City of Des Plaines v. Trottner, 34 IIl. 2d 432, 434, 216 N.E.2d 116, 117 (1966). Limited exceptions are often made for gratuitous guests, see, e.g., id., and boarders, roomers, or lodgers, see, e.g., Town of $\mathrm{N}$. Hempstead v. Griffen, 71 Misc. 2d 864, 337 N.Y.S.2d 318 (Sup. Ct. 1972).

Some ordinances make additional exceptions. See Timberlake v. Kenkel, 369 F. Supp. 456 (E.D. Wis. 1974), vacated and remanded, 510 F.2d 976 (7th Cir. 1975) (licensed foster home); City of Des Plaines v. Trottner, 34 IIl. 2d 432, 216 N.E.2d 116 (1966) (specified religious uses); Holy Name Hosp. v. Montroy, 153 N.J. Super. 181, 379 A.2d 299 (Law Div. 1977) (restrictions relaxed if dwelling is owner-occupied).

41. See, e.g., City of Newark v. Johnson, 70 N.J. Super. 381, 175 A.2d 500 (Essex County Ct., Law Div. 1961); ST. Petersburg BeACH, Fla., Comprehensive Zoning OrdinanCE $§ 1$ (1972), reprinted in MODERN LEGAL FORMS § 10214.5 (Supp. 1980). Some ordinances permit unrelated groups in designated areas only as a conditional use. See, e.g., City of Chula Vista v. Pagard, 159 Cal. Rptr. 29 (1979), vacated, 115 Cal. App. 3d 785, 171 Cal. Rptr. 738 (1981); Pcople v. Renaissance Project, Inc., 36 N.Y.2d 65, 324 N.E.2d 355, 364 N.Y.S.2d 885 (1975).

42. See, e.g., People v. Kalayjian, 76 Misc. 2d 1097, 352 N.Y.S.2d 115 (Sup. Ct. 1973); NIMLO MODEL ZONING ORDINANCE \& 11-204(18) (C. Rhyne ed. 1954).

43. See, e.g., Kirsch Holding Co. v. Borough of Manasquan, 59 N.J. 241, 281 A.2d 513 (1971); Larson v. Mayor of Spring Lake Heights, 99 N.J. Super. 365, 240 A.2d 31 (Law Div. 1968). Ironically, some resort commumities in the province of Ontario, Canada, have employed zoning for direct social control to require that the occupancy of dwelling umits be exclusively seasonal. Evidently the municipalities are concerned that servicing problems could arise if the dwellings were used on a year-round basis. See, e.g., Horseshoe Valley Ltd.. v. Township of Medonte, 79 D.L.R.3d 156 (Ont. H.C. 1977); Mueller v. Township of Tiny, 72 D.L.R.3d 28 (Ont. H.C. 1976).

44. See, e.g., Berger v. State, 71 N.J. 206, 218, 364 A.2d 993, 999 (1976). Solne municipalities have adopted unusual definitions of family that recognize only certain categories of related individuals in an apparent attenpt to establish limits on the extended family. One such provision 
Though in recent years soine municipalities have replaced the single housekeeping unit formulation with a traditional-family definition, ${ }^{45}$ it would be misleading to view the history of simgle-family zoning ordimances as an even progression from less restrictive to more restrictive definitions of family. ${ }^{46}$ It appears, however, that early imstances of defining family in terms of legal and biological relationships did not foster any litigation, perliaps because this type of definition did not become widespread until later years, or perhaps because most domestic groups in this early period lived in the context of a traditional family. Today there is no lack of litigation. From quite insignificant beginnings in the $1950 \mathrm{~s},{ }^{47}$ cases considering traditional-family definitions in zoning ordinances occurred more frequently in the next decade $^{48}$ and became commonplace in the 1970s. ${ }^{49}$ The inclusion of this

states "[c]ousins, nephews, nieces, etc., shall not be considered a part of a family so defined." YPSILANTI, MICH., CODE $\$ 209.00$ (1957) (amended 1967); see also City of White Plains v. Ferraioli, 34 N.Y.2d 300, 304, 313 N.E.2d 756, 758, 357 N.Y.S.2d 449, 451 (1974). The definition of family in another zoning ordinance recognizes only "direct lineal descendants and adopted children" of "one or two persons" as relatives. TROY, MICH., ZONING ORDINANCE § 5.2(30), reprinted

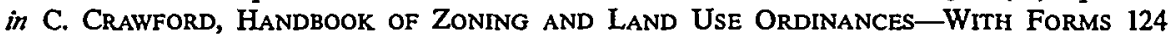
(1974). Solne of these definitions can produce peculiar results. For instance, the definition considered in one case allowed two siblings to live with their grandnother but permitted only one child to live with ler if the children liappened to be cousins. See Moore v. City of E. Cleveland, 431 U.S. 494 (1977).

45. See, e.g., Prospect Gardens Convalescent Hoine, Inc. v. City of Norwalk, 32 Conn. Supp. 214, 347 A.2d 637 (C.P. 1975) (cliange fron "single housekeeping unit" formulation to traditionalfamily definition inade in 1974); Town of Durlıam v. White Enters., 115 N.H. 645, 348 A.2d 706 (1975) (similar change inade in 1971).

46. At least one city adopted a definition referring to the legal and biological relationships of household nembers in the year after the Suprene Court's decision in Euclid. See PITTSBURGH, Pa., General ORdinances $\$ 1887$ (1938):

Family: Two or more persons related by blood or marriage living together; or one or nore persons mamtaining wholly or partly other persons, all of them living together in one household; not einbracing clubs, fratemities, boarding or rooming houses or other groups of individuals living together.

(Clause added by Ordinance No. 537, ap. June 30, 1927, O.B. 39, page 89) (empliasis added). Other municipalities adopted zoning restrictions iucorporating traditional-family definitions relatively early. See, eg., Cook County, Ill., Zoning Ordinance $\$ 22$ (1940); Detroit, Mich., Official Zoning Ordinance $\$ 2.13$ (1945); LOS ANGELES, CAL., CODE $\$ 12.00$ (1946). In 1928, the Village of Grosse Pointe Farms, Michigan, adopted the following definition:

FAMILY-A family is one or two persons or parents with their direct descendants and adopted children (and including the dounestic employees thereof) together with not inore than five persons not so related, living together in a roonl or rooins coinprising a single housekeeping unit. Every additional group of five or less persons living in such housekeeping unit shall be considered a separate family for the purposes of this ordinance.

Grosse Pointe Farms, Mich., Zoning Ordinance § I(15) (1928).

47. See, e.g., Young v. Montgounery County, 216 Md. 341, 140 A.2d 527 (1958); Kellog v. Joint Council of Wounen's Auxiliaries Welfare Ass'n, 265 S.W.2d 374 (Mo. 1954).

48. See, e.g., City of Des Plaines v. Trottner, 34 Ill. 2d 432, 216 N.E.2d 116 (1966); Larson v. Mayor of Spring Lake Heights, 99 N.J. Super. 365, 240 A.2d 31 (Law Div. 1968); Marino v. Mayor of Norwood, 77 N.J. Super. 587, 187 A.2d 217 (Law Div. 1963); City of Newark v. Johnson, 70 N.J. Super. 381, 175 A.2d 500 (Essex County Ct., Law Div. 1961). 
type of definition of family in model zoning ordinances ${ }^{50}$ and widely used form books ${ }^{51}$ undoubtedly contributed to the increasing acceptance of such zoning by inunicipalities, and one result was more litigation.

The increasing prevalence of traditional-family ordinances represents an increase in zoning for direct social control. An ordinance that defines family with respect to the legal and biological interrelationships of its meinbers exercises such control: land users are authorized to live in a residential district, or potential land users are excluded, on the

49. See, e.g., Moore v. City of E. Cleveland, 431 U.S. 494 (1977) (plurality); Village of Belle Terre v. Boraas, 416 U.S. 1 (1974); Timberlake v. Kenkel, 369 F. Supp. 456 (E.D. Wis. 1974), vacated and remanded, 510 F.2d 976 (7th Cir. 1975); Palo Alto Tenants Union v. Morgan, 321 F. Supp. 908 (N.D. Cal. 1970), affd per curiam, 487 F.2d 883 (9th Cir. 1973); City of Chula Vista v. Pagard, 159 Cal. Rptr. 29 (1979), vacated, 115 Cal. App. 3d 785, 171 Cal. Rptr. 738 (1981); Hessling v. City of Broomfield, 193 Colo. 124, 563 P.2d 12 (1977); Rademan v. City of Denver, 186 Colo. 250, 526 P.2d 1325 (1974); Prospect Gardens Convalescent Home, Inc. v. City of Norwalk, 32 Conn. Supp. 214, 347 A.2d 637 (C.P. 1975); Village of River Forest v. Midwest Bank \& Trust Co., 12 Ill. App. 3d 136, 297 N.E.2d 775 (1973); City of Takoma Park v. County Bd. of Appeals, 259 Md. 619, 270 A.2d 772 (1970); Association for Educ. Dev. v. Hayward, 533 S.W.2d 579 (Mo. 1976); State ex rel. Ellis v. Liddle, 520 S.W.2d 644 (Mo. Ct. App. 1975); State ex rel. Thelen v. City of Missoula, 168 Mont. 375, 543 P.2d 173 (1975); Town of Durham v. White Enters., 115 N.H. 645, 348 A.2d 706 (1975); State v. Baker, 81 N.J. 99, 405 A.2d 368 (1979); Berger v. State, 71 N.J. 206, 364 A.2d 993 (1976); Kirseh Holding Co. v. Borough of Manasquan, 59 N.J. 241, 281 A.2d 513 (1971); Gabe Collins Realty, Inc. v. City of Margate City, 112 N.J. Super. 341, 271 A.2d 430 (App. Div. 1970); Holy Name Hosp. v. Montroy, 153 N.J. Super. 181, 379 A.2d 299 (Law Div. 1977); YWCA of Summit v. Board of Adjustment, 134 N.J. Super. 384, 341 A.2d 356 (Law Div. 1975), affd, 141 N.J. Super. 315, 358 A.2d 211 (App. Div. 1976); Group House of Port Washington, Inc. v. Board of Zoning \& Appeals, 45 N.Y.2d 266, 380 N.E.2d 207, 408 N.Y.S.2d 377 (1978); People v. Renaissance Project, Inc., 36 N.Y.2d 65, 324 N.E.2d 355, 364 N.Y.S.2d 885 (1975); City of White Plains v. Ferraioli, 34 N.Y.2d 300, 313 N.E.2d 756, 357 N.Y.S.2d 449 (1974); Little Neck Community Ass'n v. Working Org. for Retarded Children, 52 A.D.2d 90, 383 N.Y.S.2d 364 (1976); Town of Ithaca v. Lucente, 36 A.D.2d 560, 317 N.Y.S.2d 679 (1971); Abbott House v. Village of Tarrytown, 34 A.D.2d 821, 312 N.Y.S.2d 841 (1970); Incorporated Village of Freeport v. Association for the Help of Retarded Children, 94 Misc. 2d 1048, 406 N.Y.S.2d 221 (Sup. Ct. 1977); People v. Kalayjian, 76 Misc. 2d 1097, 352 N.Y.S.2d 115 (App. Term 1973); Town of N. Hempstead v. Griffen, 71 Misc. 2d 864, 337 N.Y.S.2d 318 (Sup. Ct. 1972); People v. Skidınore, 69 Misc. 2d 320, 329 N.Y.S.2d 881 (Village Justice Ct. of Sea Cliff 1971); Culp v. City of Seattle, 22 Wash. App. 618, 590 P.2d 1288 (1979); Browndale Int'l, Ltd. v. Board of Adjustment, 60 Wis. 2d 182, 208 N.W.2d 121 (1973), cert. denied, 416 U.S. 936 (1974). In a recent survey of Montana localities two-thirds of the responding municipalities had adopted some form of traditional-family ordinance. See Note, The Definition of "Family" in Single-Family Zoning, 42 MoNT. L. Rev. 165, 181-82 (1981).

50. See, e.g., F. Bair \& E. Bartley, The Text of a Model Zoning Ordinance, With Commentary 68 (2d ed. 1960); L. Kendio, Performance Zoning 105 (1980) (model ordinance); T. MATthews, DRAFTino Municipal ORdINANCES 323 (1956); NIMLO MOdEl ZoNino ORDINANCE \& 11-204(18) (C. Rhyne ed. 1954).

51. See, e.g., AM. JUR. 2D, LeGAL Forms § 268.34 (1974) ("Family: A number of individuals related by blood, marriage or adoption living and cooking together on the premises as a single housekceping umit and including domestic employees."); MODERN LEGAL FORMS \& 10214.5 (Supp. 1980). 
basis of marital or family status, relatively immutable personal characteristics explicitly identified in the ordinance. What motivated the development and adoption of these traditional-family ordinances? ${ }^{52}$ One way to find out is to examine cases considering definitions of traditional families to ascertain what governmental objectives are cited as reasons for these restrictions. 53

\section{B. Purported Goals of Zoning for the Traditional Family.}

Many of the ends that traditional-family ordinances are said to promote are conventional zoning goals. The Standard State Zoning Enabling Act ${ }^{54}$ by and large encapsulates these goals:

Such regulations shall be in accordance with a comprehensive plan and designed to lessen congestion in the streets; to secure safety from

52. Ordinances defining family with respect to legal and biological relationships almost always make an exception for some number of unrelated individuals. See supra note 40 and accompanying text. Therefore, when this article states that a zoning ordinance limits a district to traditional families, or discusses a "traditional-family ordinance", the reader should assume, unless the context indicates otherwise, that unrelated persons are not totally excluded.

53. Another way to answer this question would be to examine, among other things, what members of local governing bodies said when adopting such ordinances. In inany instances, however, this sort of record will be unavailable. With respect to one traditional-family ordinance it was said "[t]here exist no City Council minutes nor committee reports which might assist this Court in identifying the purposes of the ordinance in question." Brief for Appellant at 42, Moore v. City of E. Cleveland, 431 U.S. 494 (1977) (plurality) (footnote omitted). Also, it may very well be that little discussion would preface the adoption of such provisions because they are accepted largely on the recommendation of a municipal solicitor or planning staff member who previously examined a model ordinance or form book for an acceptable formulation. See R. ELLICKSON \& A.D. TARLOCK, LAND-USE CONTROLS 56 (1981) ("As in other areas of law, those who draft zoning ordinances rely heavily on standard forms and language developed and tested by those who have gone before."). Unfortunately, such form books and model ordinances contain little, if any, explanation of why they suggest a traditional-family definition. See, e.g., F. BAIR \& E. BARTLEY, supra note 50, at 80 . On the preparation and use of model ordinances, see generally E. GREENman, Codification of Ordinances 9-10 (Municipal Administrative Service Pub. No. 6, 1928); C. RHYNE, B. RHYNE, \& E. MEANS, Codification OF MUNICIPAL ORdinaNces 27-29 (National Institute of Municipal Law Officers Report No. 147, 1961).

54. The Standard Act was model legislation developed by the United States Department of Commerce in the 1920 s for delegating the zoning power from state to local governments. It was instrumental in the rapid spread of zoning throughout the country, see E. BASSETT, supra note I, at 29 , and was eventually adopted in some form by all fifty states. In 1974 it remained in effect in forty-seven states. See 1 N. WILLIAMS, supra note 9, $\S 18.01$ (1974). The explanatory notes of the draftsinen encouraged state legislatures to modify the Standard Act as little as possible when adopting enabling legislation. See United States Dep't of Comunerce, Standard State Zoning Enabling Act, reprinted in ALI MOdel LAND Development Code app. A, 212 (Tent. Draft No. 1, 1968) (draftsmen's explanatory note) [heremafter cited as Standard Act]. See generally, R. ANDERSON \& B. Roswig, Planning, Zoning \& Subdivision: A Summary of Statutory Law in the 50 STATES (1966). The Standard Act and variations thereon are discussed in 1 N. WILLIAMS, supra note 9, ch. 18 (chart presentation at 361-70), and in Cunningham, Land-Use Control-The State and Local Programs, 50 IowA L. REv. 367, 367-80 (1965). In recent years some states liave enacted zoning and planning statutes that depart significantly from the wording of the Standard Act. See R. ElLICKSON \& A.D. TARLOCK, supra note 53, at 37. 
fire, panic, and other dangers; to promote health and general welfare; to provide adequate light and air; to prevent the overcrowding of land; to avoid undue concentration of population; to facilitate the adequate provision of transportation, water, sewerage, schools, parks, and other public requirements. Such regulations shall be made with reasonable consideration, among other things, to the character of the district and its peculiar suitability for particular uses, and with a view to conserving the value of buildings and encouraging the most appropriate use of land throughout such municipality. 55

Of these objectives, population density control is the one most commonly cited im support of zoning ordinances defining family with reference to the legal and biological composition of the domestic unit. ${ }^{56}$ Apparently, it is argued that traditional-family ordinances will prevent overcrowdimg because traditional families tend to be self-limitimg and unrelated groups do not. ${ }^{57}$ A number of other zoning objectives are also closely associated with controlling the density of development. 58 Problems of traffic and parking are frequently given as reasons for the adoption of zoning restrictions authorizing only conventional families to reside in a district ${ }^{59}$ because a group of unrelated individuals would allegedly be more likely to create traffic and parking problems than an unrelated group of the same size. ${ }^{60}$ Another standard concern is the problein of increased noise. ${ }^{61}$ For instance, the raucous behavior of fraternities, ${ }^{62}$ and of unrelated groups in resort communities, ${ }^{63}$ has apparently prompted the adoption of restrictive definitions of family. Lo-

55. Standard Act, supra note $54, \S 3$.

56. See, e.g., Moore v. City of E. Cleveland, 431 U.S. 494, 499-500 (1977) (plurality); Palo Alto Tenants Union v. Morgan, 321 F. Supp. 908, 912 (N.D. Cal. 1970), aff'd, 487 F.2d 883, 884 (9th Cir. 1973); City of Chula Vista v. Pagard, 159 Cal. Rptr. 29, 33 (1979), vacated, 115 Cal. App. 3d 785, 171 Cal. Rptr. 738 (1981); Kellog v. Joint Council of Wonen's Auxiliaries Welfare Ass'n, 265 S.W.2d 374, 378 (Mo. 1954).

57. See, e.g., Timberlake v. Kenkel, 369 F. Supp. 456, 467 (E.D. Wis. 1974), vacated and remanded, 510 F.2d 976 (7th Cir. 1975); Brief for Appellants at 32, Village of Belle Terre v. Boraas, 416 U.S. 1 (1974). But see Note, "Burning the House to Roast the Pig": Unrelated Individuals and Single Family Zoning's Blood Relation Criterion, 58 CoRnell L. REv. 138, 156 n.102 (1972).

58. One goal, adequate provision for light and air, is not usually linked with traditionalfamily ordinances. But see Village of Belle Terre v. Boraas, 416 U.S. 1, 9 (1974) (discussing "the blessings . . . of clean air").

59. See, eg., Moore v. City of E. Cleveland, 431 U.S. 494, 500 (1977) (plurality); Village of Belle Terre v. Boraas, 416 U.S. 1, 9, 18 (1974); Larson v. Mayor of Spring Lake Heights, 99 N.J. Super. 365, 369, 240 A.2d 31, 33 (Law Div. 1968).

60. See City of Des Plaines v. Trottner, 34 Ill. 2d 432, 437, 216 N.E.2d 116, 119 (1966).

61. See, e.g., Village of Belle Terre v. Boraas, 416 U.S. 1, 9, 18 (1974); Kirsch Holding Co. v. Borough of Manasquan, 59 N.J. 241, 245, 281 A.2d 513, 515 (1971).

62. Pettis v. Alpha Alpha Clapter of Phi Beta Pi, 115 Neb. 525, 530, 213 N.W. 835, 837-38 (1927) (describes standard view of fraternity behavior). The definition of family found in one model ordinance would restrict occupancy of a housekeeping unit to related persons. The commentary to the ordinance explains: "[t]he definition is definitely intended to prevent fraternity 
cal councils hope that with parental or other supervision will come peace and quiet. ${ }^{64}$ In some cases, avoiding an undue burden on public services has also been cited in support of traditional-family regulations, ${ }^{65}$ an argument apparently associated with the density rationale.

It has frequently been said that traditional-family zoning provisions further the goal of protectimg property values. ${ }^{66}$ It has been argued that an "end of single-family housing will make the community less aesthetic, will result in more traffic and more children, will reduce the quality of police, fire, transportation, and educational services and, consequently, will drive property values down."67 Another economic rationale often used to support ordinances excluding all but traditional familics or a limited number of unrelated individuals is that this type of ordinance ensures the availability of appropriate accommodations for traditional families by preventing the rental (or sale) of houses to groups of unrelated persons wlio, because of their independent sources of income, might be able to pay a higher price than traditional families. ${ }^{68}$ In other words, zoning ordinances with traditional-family definitions allegedly preserve the structure of housing costs and prevent inflated property and rental prices. ${ }^{69}$

and sorority houses . . . from taking on a simgle-family status." F. BAIR \& E. BARTLEY, supra note 50 , at 80 .

63. See, e.g., Kirsch Holding Co. v. Borough of Manasquan, 59 N.J. 241, 281 A.2d 513 (1971); Gabe Collins Realty, Inc. v. City of Margate City, 112 N.J. Super. 341, 271 A.2d 430 (App. Div. 1970).

64. See Larson v. Mayor of Spring Lake Heights, 99 N.J. Super. 365, 369-70, 240 A.2d 31, 33 (Law Div. 1968) (Public officials felt problems "were due largely to the absence of parental or other supervision and control within the premises.").

65. See Moore v. City of E. Cleveland, 431 U.S. 494, 501 (1977) (plurality) (school system); Timberlake v. Kenkel, 369 F. Supp. 456, 460, 467 (E.D. Wis. 1974), vacated and remanded, 510 F.2d 976 (7th Cir. 1975) (services in general).

66. See, e.g., Timberlake v. Kenkel, 369 F. Supp. 456, 460, 465, 466, 467 (E.D. Wis. 1974), vacated and remanded, 510 F.2d 976 (7th Cir. 1975); Larson v. Mayor of Spring Lake Heights, 99 N.J. Super. 365, 370, 240 A.2d 31, 34 (Law Div. 1968); City of Newark v. Johnson, 70 N.J. Super. 381, 387, 175 A.2d 500, 503 (Essex County Ct., Law Div. 1961). For a general discussion of protecting property values, see E. BASSETT, supra note 1, at 52-53 (protection of values should remain distinct froin the imcrease of values, as the latter is not a proper purpose of zoning).

67. Timberlake v. Kenkel, 369 F. Supp. 456, 467 (E.D. Wis. 1974), vacated and remanded, 510 F.2d 976 (7th Cir. 1975).

68. See, e.g., Village of Belle Terre v. Boraas, 416 U.S. 1, 18-19 (1974); Palo Alto Tenants Union v. Morgan, 321 F. Supp. 908, 912-13 (N.D. Cal. 1970), affd, 487 F.2d 883 (9th Cir. 1973). Of course, depending on the quality of housing in a given district, not all traditional families may find it economically feasible to participate. See, e.g., Rademan v. City of Denver, 186 Colo. 250, 253, 526 P.2d 1325, 1327 (1974) (two traditional families jointly purchasing house, neither family capable of effecting purchase without the financial assistance of the other). Thus, as with other types of residential zoning, it appears that ordinances limiting areas to traditional families can potentially have an exclusionary effect.

69. See Timberlake v. Kenkel, 369 F. Supp. 456, 467 (E.D. Wis. 1974), vacated and remanded, 510 F.2d 976 (7th Cir. 1975). Courts considering this type of ordinance as enacted by 
Less conventional zoning goals also allegedly support traditionalfamily ordinances. The extent to which the zoning power may be exercised in furtherance of inunicipal aesthetics has long occupied courts and commentators alike. ${ }^{70}$ In the early years an aesthetic purpose alone would not be adequate support for a zoning ordmance, although aesthetic purposes could be recognized if a regulation was primarily based on considerations of public health and safety. ${ }^{71}$ Ultimately, however, the Supreine Court signaled in Berman v. Parker 72 that governments could pursue aesthetic objectives. Mr. Justice Douglas stated that the "concept of the public welfare is broad and inclusive" and then elaborated: "The values it represents are spiritual as well as physical, aesthetic as well as nonetary. It is within the power of the legislature to determine that the community should be beautiful as well as healthy, spacious as well as clean, well-balanccd as well as carefully patrolled."73

Two decades later, in Village of Belle Terre v. Boraas, ${ }^{74}$ Douglas again recognized the legitimacy of aesthetic objectives in a similarly lyrical passage:

A quiet place where yards are wide, people few, and motor vehicles restricted are legitimate guidelines im a land-use project addressed to family needs. This goal is a permissible one within Berman v. Parker . . . . The pohice power is not confined to elimination of filth, stench, and unhealthy places. It is ample to lay out zones where family values, youth values, and the blessings of quiet seclusion and clean air make the area a sanctuary for people. ${ }^{75}$

Particularly noteworthy for our purposes, however, is that the majority in Belle Terre adopted this passage in the course of upholding a traditional-family ordinance. ${ }^{76}$

resort communities have accepted that groups of unrelated persons are able to pay more rent than conventioual families. See, e.g., Kirsch Holding Co. v. Borough of Manasquan, 59 N.J. 241, 245, 281 A.2d 513, 515 (1971); Gabe Collins Realty, Inc. v. City of Margate City, 112 N.J. Super. 341, 344, 271 A.2d 430, 431 (App. Div. 1970).

70. See generally 1 N. Williams, supra note 9 , ch. 11.

71. See, e.g., Welch v. Swasey, 214 U.S. 91, 107-08 (1909); Opinion of the Justices, 234 Mass. 597, 604, 127 N.E. 525, 528 (1920); E. BASSETT, supra note 1, at 97.

72. 348 U.S. 26 (1954).

73. Id. at 33. "Berman was not, strictly speaking, a zoning case, but involved issues of emineut domain. Nonetheless, it has been cited frequently in subsequent zoning decisions as support for the broad scope of the police power." Developments in the Law-Zoning, supra note 11, at 1443 n.8.

74. 416 U.S. 1 (1974).

75. Id. at 9.

76. See also Timberlake v. Kenkel, 369 F. Supp. 456, 467 (E.D. Wis. 1974), vacatcd and remanded, 510 F.2d 976 (7th Cir. 1975) (citing aesthetic objective in support of a traditionalfamily ordinance). Aesthetic concerns have achieved more acceptance as proper zoning goals in recent years. See 1 N. WILLIAMS, supra note 9 \$ 11.21; Developments in the Law-Zoning, supra 
A similarly amorphous concept, closely related to aesthetics, is that of the "character of the community" or "neighborhood character," the preservation of which is frequently said to underlie ordinances limiting residential areas to traditional families. ${ }^{77}$ Unquestionably there is a physical aspect to neighborhood character. ${ }^{78}$ The exclusion of industry and businesses certainly aids in establishing the character of a residential district, and Belle Terre speaks of noise, open space, population density, and traffic as elements that im part determine community character. ${ }^{79}$ Other decisions indicate that the stability of residential occupancy is also a factor. ${ }^{80}$ And rather mimor physical matters often determine whether a given land use will comport with a neighborhood's character. ${ }^{81}$ Nevertheless, the notion of community character is not limited to the quality of the physical urban environment. The concept imcludes less tangible elements: "Protection of character covers inany physical, social, economic, and psychological objectives that affect people's choices." 82 Thus, zoning becomes a regulatory tool shap-

note 11, at 1448. As "classifications . . . not based primarily on physical characteristics," NATIONAL COMmission ON URBAN PROBLems, supra note 24, at 219 , aesthetic concerns arguably support zoning based on other intangible qualities such as the composition of a household in a dwelling unit.

77. See, e.g., Moore v. City of E. Cleveland, 431 U.S. 494, 550 (1977) (White, J., dissenting); City of Santa Barbara v. Adamson, 27 Cal. 3d 123, 131, 610 P.2d 436, 440, 164 Cal. Rptr. 539, 543 (1980) (en banc); State ex rel. Ellis v. Liddle, 520 S.W.2d 644, 651 (Mo. Ct. App. 1975); Berger v. State, 71 N.J. 206, 223, 364 A.2d 993, 1002 (1976); City of White Plains v. Ferraioli, 34 N.Y.2d 300, 305, 313 N.E.2d 756, 758, 357 N.Y.S.2d 449, 452 (1974). Although zoning to preserve neighborhood character has traditionally been thought to be a legitimate purpose of zoning, it has not gone uncriticized. See 1 N. Williams, supra note 9, § 15.07; Williains, Planning Law and Democratic Living, 20 LAW \& CONTEMP. ProBs. 317, 333-34 (1955). Nor have the courts allowed neighborhood character to be pursued at the expense of other values. See Developments in the LawZoning, supra note 11, at 1452-57.

78. See Developments in the Law-Zoning, supra note 11, at 1450-51.

79. Belle Terre, 416 U.S. at 9 . Though open space is primarily a physical characteristic related to density controls, it may have symbohic weight as an abstract notion of developmental quality determined by elements like "privacy, amenity, and compatability." See NATIONAL CoMMISSION ON URBAN Problems, supra note 24, at 206 (1969).

80. See, e.g., Moore v. City of E. Cleveland, 431 U.S. 494, 516 (1977) (Stevens, J., concurring); City of White Plains v. Ferraioli, 34 N.Y.2d 300, 305, 313 N.E.2d 756, 758, 357 N.Y.S.2d 449, 452 (1974).

81. See National Commission on URBan Problems, supra note 24, at 219:

Perhaps the greatest classification problen, though, stems from the sheer number of factors that can influence compatibility - such nuatters as exact location, topography, the design of the site and the building, the location of automobile access points, maintenance, and details of operation (how late a store stays open at night, whether there is an exhaust filter on the pizza oven). Some of the details that determine compatibility nay vary over time-the quiet little drugstore that nsed to close at 10:30 now stays open all night and sells a special ice cream concoction that attracts teenagers and their cars until the small hours. The nicely maintained gas station changes hands, and the new owner leaves tires lying around and hangs up fluttery pennants.

82. Id.; see also M. MCLEAN, Zoning BufFers: Solution or PANACEA? 3 (1960) ("psychological factors" evaluated in determining compatibility). 
ing not only the physical character of the neighborhood, but "the socioeconomic character of a community" as well. ${ }^{83}$

In this context, aiming to preserve a certain community character implies zoning for social control. For example, in Belle Terre the Court refers to "family values" and "youtl values." 84 A purpose of the municipal code considered im another case was "to promote and encourage a suitable environinent for family life." 85 These vague phrases invite ideological interpretations, and this possibility must be considered: that zoning restrictions limitimg residential districts to traditional families actually liave ideological goals.

Like all police power regulations, zoning ordmances inust relate to the "public liealth, safety, morals or general welfare." 86 The first section of the Standard State Zoning Enabling Act explicitly duplicates this requirement. 87 Consequently, one might anticipate efforts to support traditional-family ordinances on the basis that sucli regulations further public morals on issues such as the colrabitation of unrelated adults. ${ }^{88}$ Traditional-family ordinances enacted by resort commumities liave been said to be aimed in part at the immoral beliavior of unrelated groups (fornication in cars parked on public streets, for instance). ${ }^{89}$ Nevertheless, tliese regulations liave sought inore to aneliorate the generally inconsiderate beliavior of these groups than to deal specifically with moral concerns. Nor have the attempts to support these ordinances relied primarily on the rationale of protecting public morals; indeed, non-resort communities liave explicitly disavowed any imtention to influence the moral behavior of coliabitimg unrelated adults, or to preserve the moral fiber of the community..$^{90} \mathrm{~A}$

83. Blumstein, A Prolegomenon to Growth Management and Exclusionary Zoning Lssues, 43 LAW \& CONTEMP. Probs. 5, 11 (1979). For instance, the zoning power can preserve a sinall New England town's “charm." Steel Hill Dev., Inc. v. Town of Sanbornton, 469 F.2d 956, 959 (1st Cir. 1972).

84. Belle Terre, 416 U.S. at 9.

85. City of Chula Vista v. Pagard, 159 Cal. Rptr. 29, 33 (1979), vacated, 115 Cal. App. 3d 785, 171 Cal. Rptr. 738 (1981).

86. See, e.g., Village of Enclid v. Ambler Realty Co., 272 U.S. 365, 395 (1926); Adkins v. Children's Hosp., 261 U.S. 525, 548 (1923).

87. Standard Act, supra note $54, \S 1$.

88. See Cope, Zoning: The Definition of Family, 62 ILL. B.J. 30, 31 (1973).

89. See, e.g., Kirsch Holding Co. v. Borough of Manasquan, 59 N.J. 241, 245, 281 A.2d 513, 515 (1971); Larson v. Mayor of Spring Lake Heights, 99 N.J. Super. 365, 369, 240 A.2d 31, 33 (Law Div. 1968).

90. See, e.g., Timberlake v. Kenkel, 369 F. Supp. 456, 465 (E.D. Wis. 1974), vacated and remanded, 510 F.2d 976 (7th Cir. 1975); Boraas v. Village of Belle Terre, 476 F.2d 806, 814 (2d Cir. 1973), rev'd, 416 U.S. 1 (1974). Arguments that local governments liad the moralistic objective of excluding unrelated couples by means of traditional-family ordimances falter in the face of the usual exceptions inade for a limited number of unrelated persons. See, e.g., Village of Bellc 
disclaimer of this kind seems wise, because at least one court has explicitly stated that a zoning objective based on the fear "that groups of unrelated persons hazard an immoral environment for families with children" would not be legitimate. ${ }^{91}$

Though the protection of morals las not figured prominently in zoning goals, ${ }^{92}$ municipalities defining family witlı respect to the legal and biological interrelationships of household members may in fact be pursuing ideological goals not far removed from the moralistic objectives noted above. These municipalities can be seen as seeking to provide affirmatively for the traditional family and all the values and ideals normally associated with it, rather than as simply prohibiting unmarried cohabitations. Thus, when Mr. Justice Douglas spoke of "family values" and "youth values" in the Belle Terre case, he referred to a municipality's allegedly legitimate interest in establishing a preserve where the ideological virtues that accompany family living might flourish. ${ }^{93}$ Other cases could be read in a similar manner. ${ }^{94}$

Clearly the law affords the family a favored position in a nuniber of contexts, ${ }^{95}$ including constitutional protection for both its nuclear and extended forms. ${ }^{96}$ Furthermore, courts have long associated the social values of family life with the very concept of zoning controls. As was noted in a leading California case: "we think it may be safely and sensibly said that justification for residential zonimg may, in the last

Terre v. Boraas, 416 U.S. 1, 8 (1974); City of Santa Barbara v. Adamson, 27 Cal. 3d 123, 139 n.2, 610 P.2d 436, 445 n.2, 164 Cal. Rptr. 539, 548 n.2 (1980) (en banc); see also supra note 40.

91. City of Santa Barbara v. Adamson, 27 Cal. 3d 123, 133, 610 P.2d 436, 441, 164 Cal. Rptr. 539, 544 (1980) (en banc); $c f$. Wilkinson \& White, Constitutional Protection for Personal LifeStyles, 62 CoRNELl L. REv. 563, 568 (1977) ("Law is a vehicle by which democratic majorities reaffirm shared moral aspirations and summon society's allegiance to a common set of behavioral goals. Deploying the Constitution to undermine conventional precepts of domestic morality is a step not lightly taken.").

92. See supra text accompanying notes $86-91 ; 1 \mathrm{~N}$. Williams, supra note $9, \S 8.03$ (1974); Developments in the Law-Zoning, supra note 11, at 1445.

93. See Village of Belle Terre v. Boraas, 416 U.S. 1, 9 (1974); see also Boraas v. Village of Belle Terre, 367 F. Supp. 136, 146 (E.D.N.Y. 1972), affd, 416 U.S. 1 (1974).

94. See, e.g., Palo Alto Tenants Union v. Morgan, 321 F. Supp. 908, 912 (N.D. Cal. 1970), affd per curiam, 487 F.2d 883 (9th Cir. 1973); Rademan v. City of Denver, 186 Colo. 250, 254-55, 526 P.2d 1325, 1327 (1974); Town of Durham v. White Enters., 115 N.H. 645, 649, 348 A.2d 706, 709 (1975).

95. See, e.g., Town of Durham v. White Enters., 115 N.H. 645, 649, 348 A.2d 706, 709 (1975). The author of a legal inanual for individuals who wish to pursue a communal style of living opens by noting that one of his fundamental assumptions is that the legal system in the United States is designed to maintain "cohesive, socially productive family units." L. Goldstern, CoMmUNES, LAW \& COMMONSENSE 1 (1974). Cf. Wilkinson \& White, supra note 91, at 595 ("Preserving the strength of this basic, organic unit [the nuclear, heterosexual family] is a central and legitimate end of the police power").

96. See Moore v. City of E. Cleveland, 431 U.S. 494 (1977) (plurality). 
analysis, be rested upon the protection of the civic and social values of the American home." 97 Many commentators have also tied family values to zoning. In the first edition of his treatise on zoning, James, Metzenbaum asserts that "[a] proper administration of zoning laws will go far toward preserving the American Home-that institution which has been referred to repeatedly as the backbone and the mainstay of our country." 98 And in his Euclid brief Alfred Bettman noted that people seek to purchase their own homes because they prefer to raise their children in a moral environinent. 99

Ultimately, however, it is difficult to assess the strength of the association between the social values of family life and the upholding of traditional-family ordimances by the judiciary. ${ }^{100}$ For instance, some judges have read Belle Terre and its language of "family values" and "youth values" to refer only to the creation of an appropriate physical environment for family living. ${ }^{101}$ Others have seen the decision of the

97. Miller v. Board of Pub. Works, 195 Cal. 477, 492-93, 234 P. 381, 386 (1925), appeal dismissed, 273 U.S. 781 (1927). The court went on to specify some of these values:

The establishment of single family residence districts offers inducements, not only to the wealthy, but to those of moderate means to own their own homes. With ownership comes stability, the welding together of family ties, and better attention to the rearing of children. With ownership comes increased interest in the promotion of public agencies, such as church and school, which have for their purpose a desired development of the inoral and mental make-up of the citizenry of the country. With ownership of one's home comes recognition of the imdividual's responsibility for his share in the safeguarding of the welfare of the community and increased pride in personal achievement which must come from personal participation in projects looking toward community betterment.

Id. at 493, 234 P. at 387; see also State ex rel. Twin City Bldg. \& Inv. Co. v. Houghton, 144 Minn. 13, 20, 176 N.W. 159, 162 (1920), rev'g 144 Minn. 1, 174 N.W. 885 (1919); City of Bismarck v. Hughes, 53 N.D. 838, 851-52, 208 N.W. 711, 716-17 (1926); Fraser v. Fred Parker Funeral Home, 201 S.C. 88, 96-97, 21 S.E.2d 577, 581 (1942) (action in nuisance).

98. J. MeTZENBAUM, supra note 36, at 8 . Metzenbaum was counsel for the inunicipality in the Euclid case. Another early commentator suggested that districts zoned only for residences provided "more moral surroundings." Note, Delimitation of the State Police Power as to Building Restrictions, 26 YALE L.J. 151, 152 (1916).

99. A. Bettman, Euclid Brief, reprinted in City and Regional Planning Papers 175 (1946). The explanation for the almost unquestioning solicitude afforded the single-family detached dwelling may very well he in the tenets of social anthropology. According to one author, "[a] sacred quality endows both the family and its 'home,' sacred in the sense of being set apart from the mundane and having a distinctive aura." C. PERIN, supra note 16, at 47.

100. See generally Williams \& Doughty, Studies in Legal Realism: Mount Laurel, Belle Terre and Berman, 29 RuTGers L. Rev. 73, 79-80 (1975); Note, supra note 34, at 1476-77. Clearly the Village of Belle Terre sought to have ideological goals associated with its ordinance. "An abundance of stable families to provide an environunent comportable with parents' ideals for raising their children is an end which the ordinance does in fact promote." Brief for Appellants at 15, Village of Belle Terre v. Boraas, 416 U.S. 1 (1974).

101. See City of Chula Vista v. Pagard, 115 Cal. App. 3d 785, 799-800, 171 Cal. Rptr. 738, 746-47 (1981) (viewing promotion of family values entirely in terms of creating an appropriate physical environunent); City of White Plains v. Ferraioli, 34 N.Y.2d 300, 304-05, 313 N.E.2d 756, 758, 357 N.Y.S.2d 449, 452 (1974) (suggesting Belle Terre was primarily concerned with the pre- 
Supreme Court as contemplating intangible concepts independent of the physical aspects of urban design. ${ }^{102}$ The word "values" used in Belle Terre and in other cases ${ }^{103}$ certainly suggests that ideological goals were thought to be at stake.

In general, inany of the broad range of zoning goals associated with traditional family ordinances-notably those of protecting the community character, aesthetics, and promoting abstract notions associated with family life-are rather far removed from the explicit concerns of the founders of zoning. At the saine time, lowever, there remains a reluctance to wander too far from the traditional lealth and safety goals. Density control and related matters are still tlie inost coinmon goals used to support traditional-family ordinances, and in no case has such a regulation been supported with no reference at all to the tangible aspects of the urban environinent. Thus, this nore established branch of zoning for direct social control retains its roots in the physical rationales for zoning.

\section{Enter the Courts: Constitutional Issues and Substantive Review.}

Judicial review in otler areas of the law nay create controversy, but "it has always been recognized that it is an essential part of the judicial function" for courts to watch over the actions of local governments. ${ }^{104}$ Perhaps the activist attitude of the courts reveals a fundamental "fear of popular majorities." 105 In any event, each judicial examination of a zoning ordinance weighs public interest against pri-

vention of transiency); see also Moore v. City of E. Cleveland, 431 U.S. 494, 519 n.15 (1977) (Stevens, J., concurring).

102. See Town of Durham v. White Enters., 115 N.H. 645, 649, 348 A.2d 706, 709 (1975) (traditional family ordinance upheld in spite of the "fact that unrelated group use does not constitute a different [physical] use than that by the blood related family group"); see also City of Chula Vista v. Pagard, 159 Cal. Rptr. 29, 32-33 (1979) (report of chief associate planner finding "no difference in land use impact between a related family of 10 and an unrelated family of 10 "), vacated, 115 Cal. App. 3d 785, 171 Cal. Rptr. 738 (1981); cf. Boraas v. Village of Belle Terre, 367 F. Supp. 136, 145 (E.D.N.Y. 1972) ("The question ultimately posed is whether it is lawful to have a one-family dwelling zoning district which excludes equally small household groups who impose no greater burdens of use on the land, the building or the surroundings than a blood-and-inarriage family group on the sinple and bare ground that such student groups are not families made up of husband, wife and children."), aff d, 416 U.S. 1 (1974).

103. See, eg., City of Santa Barbara v. Adamson, 27 Cal. 3d 123, 128, 610 P.2d 436, 438, 164 Cal. Rptr. 539, 541 (1980) (en banc) ("Valid laws can, of course, be written to help promote' and protect values that family life enhances.").

104. Williams, supra note 77, at 318; see also E. FreUnd, The POLICE POWER §63, at 57 (1904).

105. Corwin, The Supreme Court and the Fourteenth Amendment, 7 Mrch. L. Rev. 641, 670 (1909). 
vate deprivation, and in so doing defines the legitimate objectives of planning and the limits of the pohice power. ${ }^{106}$

A court always has the option of determining that a traditionalfamily ordinance exceeds the power delegated to the mumicipahty in the enabling legislation. ${ }^{107}$ Nevertheless, courts have reviewed traditional-family zoning restrictions almost exclusively on constitutional bases. ${ }^{108}$ The outcoines have varied greatly, in part because soine state courts construe state constitutions as affording protections that differ soinewhat froin the guarantees included in the federal Constitution. For example, the highest court in New Jersey refused to follow the Supreme Court's decision in Belle Terre, noting that a New Jersey court nay interpret its state constitution as it sees fit. ${ }^{109}$ Furthermore, federal courts, unlike their state counterparts, hesitate to interfere in zoning matters because zoning is an exercise of the police power reserved to the states. ${ }^{110}$ But the constitutional primciples involved, whether originating from federal or state guarantees, are similar and invite a more integrated approach to these cases in order to determine when a traditional-family ordinance should survive review.

1. Due Process. The Court in Euclid stated the basic test of substantive due process under the fourteenth ainendinent, declaring that a zoning ordinance violates due process if it is "clearly arbitrary and unreasonable, having no substantial relation to the public health, safety, morals, or general welfare." 111 State courts express tests of substantive

106. See The New Zoning at xxii (N. Marcus \& M. Groves ed. 1970).

107. This assumes, of course, that the municipality does not zone pursuant to home rule powers. In one well-known Illinois case (not involving home rule) the court invahidated a zoning ordinance, holding that the ordinance was ultra vires. This left the state legislature free to amend the enabling statute to explicitly permit the local government to zone for dircct social control with respect to traditional families, and the legislature did so. See City of Des Plaines v. Trottner, 34 IIl. 2d 432, 216 N.E.2d 116 (1966), and its ultimate consequence, Village of Rivcr Forest v. Midwest Bank \& Trust Co., 12 Ill. App. 3d 136, 138, 297 N.E.2d 775, 776 (1973) (interpreting ILL. Rev. StAT. 1967, c. 24, § 11-13-1(9)); see also State v. Baker, 81 N.J. 99, 119-20, 405 A.2d 368, 376 (1979).

108. This is true despite the well-worn maxim that a court will not decide an issue on constitutional grounds if statutory grounds will serve as well, see Ashwander v. TVA, 297 U.S. 288, 347 (1936) (concurring opinion), quoted in Moore v. City of E. Cleveland, 431 U.S. 494, 526 (1977) (Burger, C.J., dissenting); State v. Baker, 81 N.J. 99, 118-21, 405 A.2d 368, 376-78 (1979) (Mountain, J., dissenting).

109. State v. Baker, 81 N.J. 99, 112, 405 A.2d 368, 374 (1979); see also City of Santa Barbara v. Adamson, 27 Cal. 3d 123, 130 n.3, 610 P.2d 436, 440 n.3, 164 Cal. Rptr. 539, 543 n.3 (1980) (en banc); Holy Name Hosp. v. Montroy, 153 N.J. Super. 181, 185, 379 A.2d 299, 301 (Law Div. 1977); ABA Advisory Commission on Housing and Urban Growth, Housing for All. UNDER LAW 123 (R. Fishman ed. 1978).

110. See Rose, Exclusionary Zoning and Managed Growth: Some Unresolved Issues, in AFTER Mount LAURes 331 (J. Rose \& R. Rothman eds. 1977).

111. Euclid, 272 U.S. at 395; see also E. FrEUND, supra note 104, § 20, at 15. Freund makes an interesting comment on the ineaning of reasonableness: "In discussing this question we may 
due process in similar terms; ${ }^{112}$ the primary concern is that a measure bear a reasonable relation to a legitimate governmental objective. ${ }^{113}$ As in analysis pursuant to the equal protection clause, ${ }^{114}$ substantive due process review becomes inore rigorous when a zoning ordmance intrudes upon "fundainental" liberties. For exainple, in Moore v. City of East Cleveland 115 a zoning restriction that defined family so as to make it a crime for a grandmother to live with two of her grandsons impinged upon "freedom of personal choice in matters of marriage and family life"116 and prompted a plurality of the Supreme Court to engage in a searching appraisal of the ordinance. Mr. Justice Powell, writing for the plurality, conceded that the goals said to justify the ordinance-preventing overcrowding, minimizing traffic and parking con-

safely discard all arguments drawn from the assumption that unreasonable means absurd or plainly arbitrary; statutes which deserve that designation are not much more apt to occur than judicial decisions of the like character." Id. § 63, at 58 (footnote omitted). The counsel for the municipality in Euclid wrote in the preface to his treatise on zoning that in every act associated with zoning the "guiding rule should be reasonableness." 1 J. METZENBAUM, THE LAW OF ZONING at v (2d ed. 1955). Cf. H. Werner, The Constitutionality of Zoning Regulations, in 12 STUDIES IN THE SOCIAL SCIENCES 52 (1924) (" $[$ t]lue point to be eniphasized in all zoning is reasonableness"). Another commentator states more generally that " '[d]ue process of law' comes to inean reasonable law, in the Court's opinion." Corwin, supra note 105, at 663.

112. See, e.g., Kirsch Holding Co. v. Borough of Manasquan, 59 N.J. 241, 251, 281 A.2d 513, 518 (1971).

113. See Perry, Substantive Due Process Revisited: Reflections on (and Beyond) Recent Cases, 71 Nw. U.L. Rev. 417, 419 (1976) (substantive due process "refers to the principle that a law advcrsely affecting an individual's life, liberty, or property is invalid, even though offending no specific constitutional prohibition, unless the law serves a legitimate governmental objective").

114. Cf. E. FREUND, supra note 104, $\S 611$, at 632 ("The two ideas [of due process and equal protection] are closely associated in the minds of the courts."). For a discussion of the analysis given traditional-family zoning ordinances under the equal protection clause see infra text accompanying notes $129-62$.

115. 431 U.S. 494 (1977).

116. Id. at 499. The ordinance at issue in Moore imcluded the following definition:

"Family" neeans a number of individuals related to the nominal head of the honsehold or to the spouse of the nominal liead of the houseliold living as a single lousekeeping unit in a simgle dwelling unit, but limited to the following:

(a) Husband or wife of the nominal head of the household.

(b) Ununarried children of the nominal head of the loousehold or of the spouse of the nominal head of household, provided, however, that such unmarried children have no children residing with them.

(c) Fatler or mother of the nominal head of the household or of the spouse of the nominal liead of the houseliold.

(d) Notwithstanding the provisions of subsection (b) lereof, a family may mclude not nore than one dependent married or unmarried child of the nominal head of the honsehold or of the spouse of the nominal head of the louseliold and the spouse and dependent children of such dependent child. For the purpose of this subsection, a dependent person is one who has more than fifty percent of his total support furnished for him by the nominal head of the louseliold and the spouse of the nominal head of the loouseliold. (e) A family may consist of one individual.

Id. at 496 n.2. Mrs. Moore was living with her son and his son. A second grandson of Mrs. Moore, a cousin of the first, came to live with the louseloold after his mother's death and thus the ordinance was contravened. Id. at 496-97. 
gestion, and avoiding undue financial burden on the school systemwere legitimate governmental objectives, but held that the measure in question "serve[d] them margimally, at best." 117 Consequently, the East Cleveland ordinance could not survive the rational basis test under the Court's heightened substantive due process review. In contrast, when the Court reviewed a more usual type of traditional-family ordinance that permitted any number of related individuals to hive together, the majority had no difficulty in finding a relationship between the ordinance and its alleged objectives. ${ }^{118}$

Rational relationship tests imposed in the course of substantive due process review have not always been so easily satisfied in the state courts. When confronted with an ordinance limiting a household to individuals legally or biologically related, or to no more than four unrelated individuals, the New Jersey Supreme Court in State v. Baker ${ }^{119}$ held that the measure violated the state's constitutional guarantee of due process. ${ }^{120}$ Employing an analysis of a sort that frequently appears in review pursuant to the equal protection clause, the Baker court concluded that the municipality could have accomplished its goals by less restrictive means. ${ }^{121}$

Other New Jersey cases have also displayed little judicial deference to local governing bodies in the substantive due process review of traditional-family ordinances. ${ }^{122}$ Zoning restrictions are, however, normally presumed to be valid; the legislative judgment will prevail if the validity of the zoning classification is "fairly debatable." 123 The Euclid

117. Id. at 499-500. Parents from surrounding areas had been sending their children to live with relatives in East Cleveland to take advantage of the superior public school system available there. See R. Ellickson \& A.D. TARLOCK, supra note 53, at 894. See generally Brief for Appellant at 57 n.43, Moore v. City of E. Cleveland, 431 U.S. 494 (1977).

118. See Village of Belle Terre v. Boraas, 416 U.S. 1 (1974). The inunicipal goals cited were primarily the historical zoning concerns of controlling population density, traffic congestion and noise.

119. 81 N.J. 99,405 A.2d 368 (1979).

120. Id. at 114, $405 \mathrm{~A} .2 \mathrm{~d}$ at 375 . In a footnote the court indicated that the ordinance also violated the right of privacy guaranteed by the state constitution. Id. at $114 \mathrm{n} .10,405$ A.2d at 375 n.10.

121. Id. at 114,405 A.2d at 375 .

122. See, e.g., Kirsch Holding Co. v. Borough of Manasquan, 59 N.J. 241, 281 A.2d 513 (1971); Gabe Collins Realty, Inc. v. City of Margate City, 112 N.J. Super. 341, 271 A.2d 430 (App. Div. 1970); see also Payne, Delegation Doctrine in the Reform of Local Government Law: The Case of Exclusionary Zoning, 29 RUTGERS L. REv. 803 (1976). Recent exclusionary zoning opinions in New Jersey seem to seriously and unnecessarily violate the principle that "law reform decisions . . . ought to he framed in terms that are as minimally intrusive of the ordinary democratic process as possible." Id. at 804.

123. Village of Euchd v. Ambler Realty Co., 272 U.S. 365, 388 (1926). One commentator asserts that the presumption of validity "should remain the strongest in those cases where courts are least equipped to balance the competing interests," and that "legitimately debatable policy 
Court also allowed for the "inclusion of a reasonable margin to insure effective enforcement." 124 In this vein, it is often asserted that a court does not sit as a zoning board of appeals. ${ }^{125}$ Yet in the infamous Moore case, in which the municipality criminally prosecuted a grandniotler for living with her two grandsons and thus impinged upon a "fundamental" personal liberty, the Court disavowed any presumption of validity. ${ }^{126}$ Some courts may even reverse the presumption of validity when assessing traditional-family ordinances. One New Jersey court, in considering a measure enacted by a resort community to combat "group rentals," clearly indicated that the usual burden had shifted: "Before this court will uploold as reasonable a police prohibition as pervasive as the present one, its necessity in relation to the evil involved will have to be shown ... a least to the extent of resurrecting the presumption of validity." 127

decisions in areas requiring the application of technical expertise to einpirical data sliould enjoy a very strong presumption of validity." Travalio, Suffer the Little Children-But Not in My Neighborhood: A Constitutional View of Age-Restrictive Housing, 40 OHIO ST. L.J. 295, 315 n.135 (1979). Another author has stated that "[t]raditional courts defer to local legislative judgment for several reasons: the separation of powers, a perceived lack of judicial expertise in land use matters, and the desire to allow local governmental flexibility in ineeting clianging conditions with innovative responses." Kolis, Citadels of Privilege: Exclusionary Land Use Regulations and the Presumption of Constitutional Validity, 8 HASTINGS CoNST. L.Q. 585, 588-89 (1981) (footnotes omitted); see also A. BETTMAN, supra note 99, at 178 (discussing the capacity of local governing bodies).

124. Village of Euclid v. Ambler Realty Co., 272 U.S. at 388-89.

125. See, e.g., Village of Belle Terre v. Boraas, 416 U.S. 1, 13 (1974) (Marslall, J., dissenting); Robinson v. City of Bloomfield Hills, 350 Micl. 425, 430, 86 N.w.2d 166, 169 (1957).

126. Moore v. City of E. Cleveland, 431 U.S. 494, 499 (1977) (plurality). Most courts considering the usual sort of traditional-family ordinance have applied the presumption of validity. See, eg., Rademan v. City of Denver, 186 Colo. 250, 526 P.2d 1325 (1974); Town of Durham v. White Enters., 115 N.H. 645, 348 A.2d 706 (1975); City of Newark v. Johnson, 70 N.J. Super. 381,175 A.2d 500 (Essex County Ct., Law Div. 1961); People v. Kalayjian, 76 Misc. 2d 1097, 352 N.Y.S.2d 115 (Sup. Ct. 1973); Town of North Hempstead v. Griffen, 71 Misc. 2d 864, 337 N.Y.S.2d 318 (Sup. Ct. 1972). But cf. Gabe Collins Realty, Inc. v. City of Margate City, 112 N.J. Super. 341, 271 A.2d 430 (App. Div. 1970) (court referred to presumption of validity but struck down ordinance).

127. Larson v. Mayor of Spring Lake Heights, 99 N.J. Super. 365, 375, 240 A.2d 31, 37 (Law Div. 1968). Larson involved an ordinance enacted pursuant to the mumicipality's general police power, but this does not appear to have had any bearing on the issue of the presumption of validity. See also Kirsch Holding Co. v. Borough of Manasquan, 59 N.J. 241, 243 n.1, 281 A.2d $513,514 \mathrm{n} .1$ (1971). This reversal of presumptive validity may help explain the attitude of the New Jersey courts and their particularly vigorous substantive due process review of traditionalfamily ordinances. With the burden on the local government to establish the relationship of the ordinance to its desired goals, the municipality stands in a position similar to that in which it would find itself were its measure subjected to active equal protection analysis. This lhelps to explain the similarity of the ends and means analysis employed by the New Jersey courts in their substantive due process review to the euds and ineans examination that frequeutly occurs in the course of judicial appraisal under the equal protection clause. Compare State v. Baker, 81 N.J. 99, 107-14, 405 A.2d 368, $371-75$ (1979) with Boraas v. Village of Belle Terre, 476 F.2d 806, 817 (2d Cir. 1973), rev'd, 416 U.S. 1 (1974). 
The presumption of validity has been reversed in other zoning cases, which may mdicate a trend toward less judicial deference to local legislation, and which some commentators have applauded.128 It may be argued that the balance between public interest and private liberty is best preserved by compelling a municipality to explain why it has zoned im a particularly restrictive manner. Certainly this approach, or variations of it, should not be immediately discarded in the search for means of preventimg abuses in zoning for direct social control.

2. Equal Protection. Zoning is at its very heart a system of classification, and there is a potential for inequality in the operation of any legislative system of classification. ${ }^{129}$ As a result, judges often appraise the fairness of distinctions drawn in a zoning ordinance by using the equal protection clause of the fourteenth amendment and analogous provisions of state constitutions. Equal protection analysis has traditionally followed a "two-tiered" formula.130 The first level of review requires that the challenged classification aim at a legitimate governmental purpose and, as the Court noted in Belle Terre, that the classification is "reasonable, not arbitrary ... and bears a rational relationship to a [permissible] state objective." "131 Moreover, "[a] statutory discrimination will not be set aside if any state of facts reasonably may be conceived to justify it"; 132 further, the party attacking the classification bears the burden of showing a lack of rational relationship. ${ }^{133}$

If the legislative classification turns on some constitutionally "suspect" class, such as race, or impinges upon some constitutionally protected "fundamental right," a second, higher level of equal protection analysis comes into play. The challenged law must then survive "strict

128. See, e.g., Southern Burlington County NAACP v. Township of Mount Laurel, 67 N.J. 151, 180-81, 336 A.2d 713, 728, appeal dismissed and cert. denied, 423 U.S. 808 (1975); Bosselinan, Can the Town of Ramapo Pass a Law 10 Bind the Rights of the Entire World? in LAND UsE CoNTROLS 360, 360-63 (D. Listokin ed. 1974); Sager, supra note 11, at 784-85 (1969); Note, The General Public Interest vs. The Presumption of Zoning Ordinance Validity: A Debatable Question, $50 \mathrm{~J}$. URB. L. 129 (1972); Comment, The Presumption of Constitutionality and the Law of Zoning, 1971 WASH. U.L.Q. 673.

129. E. FREUND, supra note $104, \S 611$, at 634 notes that "the idea of equality excludes in principle both particular burdens and special privileges, but admits of reasonable classification."

130. See generally Tussman \& tenBroek, The Equal Protection of the Laws, 37 CALIF. L. Rev. 341 (1949); Developments in the Law-Equal Protection, 82 HARV. L. REv. 1065 (1969).

131. 416 U.S. at 8; see also F.S. Royster Guano Co. v. Virginia, 253 U.S. 412 , 415 (1919) ("classification must be reasonable, not arbitrary, and must rest upon some ground of difference having a fair and substantial relation to the object of the legislation so that all persons similarly circumstanced shall be treated alike"); Town of Durham v. White Enters., 115 N.H. 645, 648-49, 348 A.2d 706, 708 (1975).

132. McGowan v. Maryland, 366 U.S. 420, 426 (1961).

133. See Taxpayers Ass'n v. Weymouth Township, 71 N.J. 249, 281, 364 A.2d 1016, 1033 (1976), appeal dismissed and cert. denied, 430 U.S. 977 (1977). 
scrutiny": not only must the enactment further a legitimate state objective, it must also promote a "compelling state interest." 134 Under this analysis, the burden of proof shifts to the party seeking to justify the classification. ${ }^{135}$ Obviously a legislative classification is nore likely to survive review under the first tier of analysis than under the second, particularly because it will often prove difficult to show that a traditional-family ordinance has a rational relationship to a coinpelling state interest-such as traffic safety-that could not be more easily preserved by less intrusive regulations-such as parking codes or one-way streets. ${ }^{136}$

There is some suggestion that the rigid two-tiered formula is being replaced by a more flexible analysis. ${ }^{137}$ The court of appeals in Belle Terre adopted this approach. ${ }^{138}$ In 1974 a federal district court also einployed a more flexible approach in appraising the validity of a traditional-family ordmance. This approach involved weighing "the nature of the unequal classification attacked, the nature of the adversely affected rights, and the governmental interest urged in support of the classification." 139 This flexible equal protection analysis is similar to the substantive due process review utilized by the New Jersey courts when appraising traditional-family ordinances. ${ }^{140}$ Although both of these inethodologies subject the regulations to less strict scrutimy than the "compelling state interest" test, they nevertheless place a substantial burden on the municipality to support its classification with fact rather than possibility. ${ }^{141}$

134. See Shapiro v. Thompson, 394 U.S. 618, 638 (1968).

135. See Village of Belle Terre v. Boraas, 416 U.S. 1 (1974). As Mr. Justice Marshall noted, "the onus of demonstrating that no less intrusive means will adequately protect the compelling state interest and that the challenged statute is sufficiently narrowly drawn, is upon the party seeking to justify the burden. ..." Id. at 18 .

136. See infra text accompanying notes 147-62.

137. See, e.g., Moore v. City of E. Cleveland, 431 U.S. 494, 551 (1977) (plurality) (recognition of a "somewhat less strict standard" than strict scrutiny); J. NowAK, R. RoTUNDA, \& J. YounG, HandBooK on Constitutional Law 525-26 (1978 \& Supp. 1979); Gunther, The Supreme Court 1971 Term-Forward: In Search of Evolving Doctrine on a Changing Court: A Model for a Newer Equal Protection, 86 HARv. L. REv. 1 (1972); Nowak, Realigning the Standards of Review Under the Equal Protection Guarantee-Prohibited, Neutral, and Permissive Classifications, 62 GEo. L.J. 1071 (1974).

138. Boraas v. Village of Belle Terre, 476 F.2d 806, 814 (2d Cir. 1973), rev'd, 416 U.S. 1 (1974). For a discussion of the test propounded by the court of appeals, see Note, Boraas v. Village of Belle Terre: The New, New Equal Protection, 72 Mich. L. REv. 508 (1974).

139. Tunberlake v. Kenkel, 369 F. Supp. 456, 465 (E.D. Wis. 1974), vacated and remanded, 510 F.2d 976 (7th Cir. 1975).

140. See supra notes 119-23 and accoinpanying text.

141. The court in Timberlake v. Kenkel, 369 F. Supp. 456 (E.D. Wis. 1974) held that the ordinance in question violated the equal protection clause of the fourteenth amendment and was 
In most instances, however, courts have used the traditional twotiered equal protection analysis, and have found that traditional-family ordinances do not impinge on any constitutionally protected fundamental right.142 Thus, they avoid the second level of analysis: socalled strict scrutiny. For example, in Belle Terre ${ }^{143}$ the zoning restriction prohibited six unrelated students who attended a local university from living together. A majority of the Supreme Court exammed a number of fundamental interests, mcluding rights of association, privacy, or travel, and found that these rights were not burdened by the ordinance. 144 Some state courts will, however, treat certain rights as fundamentally protected under their respective state constitutions, even when the federal Constitution provides no such protection. ${ }^{145}$ In California and New Jersey, broad imterpretations of the right of privacy have proved particularly effective in overturning traditional-family ordinances. ${ }^{146}$

Under both strict scrutiny and the lesser level of equal protection analysis, the rational relationship test must be net. ${ }^{147}$ In administering

therefore unconstitutional; see also Boraas v. Village of Belle Terre, 476 F.2d 806 (2d Cir. 1973), rev'd, 416 U.S. 1 (1974).

142. Moore v. City of E. Cleveland, 431 U.S. 494 (1977) (plurality), with the peculiar definition of family considered therein, is an exception.

143. Village of Belle Terre v. Boraas, 416 U.S. 1 (1974).

144. Sone commentators have criticized the Supreme Court's failure to perceive that freedon of association and other civil liberties were at stake in Belle Terre. See, e.g., Karst, The Freedom of Imtimate Association, 89 Y ALE L.J. 624, 686-92 (1980); Michelman, Political Markets and Community Self-Determination: Competing Judicial Models of Local Government Legitimacy, 53 IND. L.J. 145, 187-89 (1977-1978). Several state courts have followed Belle Terre, lowever, even when a traditional-family ordinance prevented groups from maintaining communal living arrangements in connection with a common religious orientation, see, e.g., Rademan v. City of Denver, 186 Colo. 250, 526 P.2d 1325 (1974); Town of Durham v. White Enters., 115 N.H. 645, 348 A.2d 706 (1975), thus raising claims of inteference with the constitutionally protected right of free exercise of religion. See City of Chula Vista v. Pagard, 159 Cal. Rptr. 29 (1979), vacated, 115 Cal. App. 3d 785, 171 Cal. Rptr. 738 (1981); Association for Educ. Dev. v. Hayward, 533 S.W.2d 579 (Mo. 1976).

145. For example, New Jersey courts will einploy a more strict scrutiny if a zoning ordinance impedes the right to deceut housing. See Taxpayers Ass'n v. Weymouth Township, 71 N.J. 249, 287, 364 A.2d 1016, 1037 (1976), appeal dismissed and cert. denied, 430 U.S. 977 (1977). In contrast, access to housing is not a fundamental right under the federal Constitution. See Lindsey v. Normet, 405 U.S. 56 (1972). Mr. Justice Brennan has applauded the efforts of state courts to construe the protections afforded by their respective state constitutions more broadly than counterpart provisions of the federal Constitution have been interpreted. See Brennan, State Constitutions and the Protection of Individual Rights, 90 HARV. L. REv. 489 (1977).

146. See City of Santa Barbara v. Adamson, 27 Cal. 3d 123, 610 P.2d 436, 164 Cal. Rptr. 539 (1980) (en banc); State v. Baker, 81 N.J. 99, 114 n.10, 405 A.2d 368, 375 n.10 (1979).

147. Courts often neglect to state which branch of equal protection analysis they use in a particular case-this omission is possibly evidence of the general lack of a clear coustitutional doctrine in zoning hitigation as a whole. See R. ElLICKSON \& A.D. TARLOCK, supra note 53, at 62; $1 \mathrm{~N}$. WILLIAMS, supra note $9, \S 4.03$, at 93. 
this test, courts frequently assess whether less restrictive or more appropriate regulatory means could have achieved the same ends. In so doing, the courts seem to be shedding their judicial role and projecting themselves into the council chambers of the various inunicipahties to contemplate alternative courses of legislative action. For example, with respect to the goal of maintaining rent structures and ensuring that traditional families are not priced out of the market, the Court of Appeals for the Second Circuit in Belle Terre thought that this goal could be better served by a system of rent controls. ${ }^{148}$ Other admittedly legitimate zoning goals have also been described as more properly achieved by means other than traditional-family ordinances. Problems of traffic and parking congestion are said to be more effectively solved by limiting the number of cars per dwelling unit, ${ }^{149}$ prohibitimg on-street parking, ${ }^{150}$ enforcing general traffic and noise ordinances, ${ }^{151}$ and requiring off-street parking. 152 "Noise and morahty," one court notes, "can be dealt with by enforcement of police power ordimances and criminal statutes" rather than by zoning. ${ }^{153}$

Similarly, many courts doubt the relationship of traditional-family ordinances to the goal of density control. They suggest solutions to overcrowding such as limiting occupancy in relation to available sleeping or bathroom facilities, ${ }^{154}$ or the amount of habitable floor space, ${ }^{155}$

148. Boraas v. Village of Belle Terre, 476 F.2d 806, 817 (2d Cir. 1973), rev'd, 416 U.S. 1 (1974). In his dissent in Belle Terre Mr. Justice Marshall also suggested the adoption of rent controls. 416 U.S. at 20. The court inay have been too hasty in suggesting this alternative: rent controls are no panacea and may only compound the problems of the poor and others seeking low-cost housing. See B. Siegan, Other People's Property $25-27$ (1976). There is the additional problein of whether a given municipality has the authority to adopt rent controls. See Brief for Appellants at 35, Village of Belle Terre v. Boraas, 416 U.S. 1 (1974).

149. See, e.g., Boraas v. Village of Belle Terre, 476 F.2d 806, 817 (2d Cir. 1973), rev'd, 416 U.S. 1 (1974); City of Santa Barbara v. Adamson, 27 Cal. 3d 123, 133, 610 P.2d 436, 441, 164 Cal. Rptr. 539, 544 (1980) (en banc).

150. See, e.g., Moore v. City of E. Cleveland, 431 U.S. 494, 520 n.16 (1977) (plurality).

151. See, e.g., Larson v. Mayor of Spring Lake Heights, 99 N.J. Super. 365, 374, 240 A.2d 31, 36-37 (Law Div. 1976).

152. See, e.g., City of Santa Barbara v. Adamson, 27 Cal. 3d 123, 133, 610 P.2d 436, 441, 164 Cal. Rptr. 539, 544 (1980) (en banc).

153. Id. accord, City of Chula Vista v. Pagard, 115 Cal. App. 3d 785, 799, 171 Cal. Rptr. 738, 746 (1981) (characterizing such ordinances as "closing-the-barn-door-after-the-horse-is-out measures").

154. See, e.g., Timberlake v. Kenkel, 369 F. Supp. 456, 467 (E.D. Wis. 1974), vacated and remanded, 510 F.2d 976 (7th Cir. 1975); City of Chula Vista v. Pagard, 115 Cal. App. 3d 785, 797, 171 Cal. Rptr. 738, 745 (1981); Kirsch Holding Co. v. Borough of Manasquan, 59 N.J. 241, 254, 281 A.2d 513, 520 (1971).

155. See, e.g., City of Santa Barbara v. Adamson, 27 Cal. 3d 123, 133, 610 P.2d 436, 441, 164 Cal. Rptr. 539, 544 (1980) (en banc); City of Chula Vista v. Pagard, 115 Cal. App. 3d 785, 797, 171 Cal. Rptr. 738, 745 (1981). 
or by restricting the number of bedrooms in a dwelling structure, ${ }^{156}$ or "by limiting each household to a specified number of adults, two or three perhaps, without limitation on the number of dependent children." 157

These various ends and means analyses demonstrate that many courts will hold local governments to a relatively high standard of precision in exercising inunicipal zoning power. Because the observations that traditional families tend to be self-limiting, are less transient, and generate less traffic than unrelated groups do not "reflect[] . . . universal truth[s],"158 a local council often cannot pursue objectives of density, traffic control, and neighborhood stability through the use of traditional-family zoning. Many courts will not countenance what they consider the "underinclusiveness and overinclusiveness" of these ordinances. ${ }^{159}$ According to these courts, the discredited ordinances do more than merely incorporate "a reasonable margin to insure effective enforcement." 160 Nor will these courts uphold such ordinances on the ground that "the police power ought to comprehend crude and unsuccessful programs as well as perfect and successful ones." 161 This attitude of review, possibly even inore than shifting the burden of proof, ${ }^{162}$ tends to prevent municipal experimentation with traditional-fanily ordinances.

3. The "Functional Family." One specialized form of review analyzes the rationahity of the characteristics an ordinance nay use to distinguish families from other collective groups. Some state courts, most notably those of New York and New Jersey, in addition to striking down traditional-family ordinances, have ruled that a local goveruing body unay deal only with certain characteristics of the traditional family in regulating the ineinbership of household units. In essence, municipalities may not make distinctions between traditional families and

156. See, e.g., Boraas v. Village of Belle Terre, 476 F.2d 806, 817 (2d Cir. 1973), rev'd, 416 U.S. 1 (1974).

157. Belle Terre, 416 U.S. at 19 (Marshall, J., dissenting) (footnote omitted). In Moore v. City of E. Cleveland, 431 U.S. 494, 520 n.16 (1977) (plurality), Mr. Justice Stevens remarked that "[t]o prevent overcrowding, a community can certainly place a limit on the nunber of occupants in a household . . . in absolute terms . . .."

158. City of Des Plaines v. Trottner, 34 IIl. 2d 432, 437, 216 N.E.2d 116, 119 (1966). The notion of faulting legislative classifications for failing to reflect universal truths recalls the "irrebuttable presumption doctrine" discussed in Note, The Irrebuttable Presumption Doctrine in the Supreme Court, 87 HARv. L. Rev. 1534 (1974).

159. See, e.g., State v. Baker, 81 N.J. 99, 110, 405 A.2d 368, 373 (1979).

160. Village of Euclid v. Ambler Realty Co., 272 U.S. 365, 388 (1926).

161. Johnson, Constitutional Law and Community Planning, 20 LAW \& ConTEMP. Pross. 199, 212 (1955).

162. See supra note 127 and accompanying text. 
domestic groups that, in the opinion of these courts, display all the pertinent qualities of a traditional family and therefore constitute "functional families."

In the course of striking down a traditional-fanily ordinance, the Supreme Court of New Jersey remarked in a recent opinion that "the core concept underlying single fainily hiving is not biological or legal relationship but, rather, its character as a single housekeeping unit."163 The court has elsewhere indicated that a inunicipality inaintaining a "fainily environment," a legitimate goal, may concern itself only with "stability" and "permanence," matters largely involving the impact of land uses on the plysical environment. 164 To this end "boarding houses, dormitory and institutional living" and similar uses could be excluded. ${ }^{165}$ By permitting councils to interfere with the internal structure of domestic units only so far as to require a bona fide single housekeeping unit, the New Jersey courts seem to place comnunity character and ideological goals beyond the reach of the pohce power as apphed through simgle-family zoning. ${ }^{166}$

The New York courts have adopted a more discerning approach. They liave defined the functional equivalent of a family in the context of applying traditional-family ordinances to "group hoines"-dwellings used for housing sucl groups as inental retardates and neglected and abandoned children. ${ }^{167}$ In City of White Plains v. Ferraioli, ${ }^{168}$ the domestic unit in a group honie for neglected and abandoned children consisted of an adult inarried couple, their two children, and ten foster children, seven of whoin were siblings. In reviewing this unit under an ordmance requiring legal and biological relationships, the court observed that "[z]onimg is intended to control types of housing and living

163. State v. Baker, 81 N.J. 99, 108, 405 A.2d 368, 372 (1979).

164. Berger v. State, 71 N.J. 206, 225, 364 A.2d 993, 1003 (1976).

165. Id.; see also Holy Name Hosp. v. Montroy, 153 N.J. Super. 181, 379 A.2d 299 (1977); Gabe Collins Realty, Inc. v. City of Margate City, 112 N.J. Super. 341, 350, 271 A.2d 430, 435 (App. Div. 1970) (suggesting that resort community might validly yet effectively curtail problem of "group rentals" by requiring that groups of unrelated imdividuals constitute bona fide single housekeeping units).

166. The New Jersey position denies recognition, at least through the use of the zoning power, to values which some commentators attribute to a variety of enduring relationships in unrelated groups as well as in the traditional family, but which do not inhere in every bona fide single housekeeping unit. As the following discussion demonstrates, it seems the same charge could not be leveled at the New York courts.

167. There has been no suggestion that the New York courts would not adhere to the functional fainily approach where a group home was not involved. The establishment of a group houne may, however, involve policy questions and state interests that would not attach to the establishment of all households comprised of unrelated people. See Developments in the LawZoning, supra note 11, at 1577-78 ("social importance of [these] small institutions").

168. 34 N.Y.2d 300, 313 N.E.2d 756, 357 N.Y.S.2d 449 (1974). 
and not the genetic or intimate internal family relations of human bemgs." 169 The court held that the minimal arrangement required to meet the ordinance's definition of family was "a group headed by a householder caring for a reasonable number of children as one would be likely to find in a biologically unitary family." 170 The court clearly permitted a proper concern for "outward appearances" and the largely physical aspects of stability and pernnanence. But it also considered the strength of the doinestic bonds and the internal structure of the household unit in assessing whether it had before it a functional family: the arrangement was "akin to a traditional family, which also may be sundered by death, divorce, or emancipation of the young."171

All of these cases ${ }^{172}$ demonstrate a judicially imposed limitation on the zoning power: inunicipahties cannot create classifications distinguishing traditional families from domestic groups that, from a land use point of view, are their functional equivalents. ${ }^{173}$ Assuming that

169. Id. at 305,313 N.E.2d at 758,357 N.Y.S.2d at 452.

170. Id. at 306,313 N.E.2d at 759,357 N.Y.S.2d at 453.

171. Id. at 305,313 N.E.2d at 758,357 N.Y.S.2d at 452 . In a subsequent case, Group House v. Board of Zoning \& Appeals, 45 N.Y.2d 266, 380 N.E.2d 207, 408 N.Y.S.2d 377 (1978), the New York Court of Appeals again suggested that a municipality might validly look to the internal structure of a group home in addition to its external appearance. The proposed group home in question consisted of two surrogate parents and seven children who would be drawn from the community because of their unhappy home life. The children would return to their natural families if and when this became possible. The court carefully examined the characteristics of the domestic unit, including its stability and permanency, but also used language of more intangible objectives when it stated that the group home "would in no way detract from the family and youth values which one-family zoning is imtended to protect," and in fact, "might actually support and further those values even more effectively than certaim natural families." Id. at 273,380 N.E.2d at 210,408 N.Y.S.2d at 381 . The dissenting judge enumerated the relevant considerations, stating that "[u]ltimately, the question is whether in theory, size, appearance, and structure the home is set up to emulate a family." Id. at 277, 380 N.E.2d at 213, 408 N.Y.S.2d at 383 (Breitel, C.J., dissenting). Cf. L. TRIBE, AMERICAN Constitutional LAW 989-90 (1978) (arguing that traditional family functions inhere in a wide variety of enduring relationships and that governmental interference with any such relationship should be precluded unless compellingly justified); Note, Group House of Port Washington v. Board of Zoning \& Appeals: Encroachment of Community Residences Into Single-Family Districts, 43 ALB. L. REv. 539, 544 (1979) (suggesting that the court looked to the overall purpose and intended effect of the group home).

172. See also, e.g., Hessling v. City of Broomfield, 193 Colo. 124, 563 P.2d 12 (1977); State $e x$. rel. Ellis v. Liddle, 520 S.W.2d 644 (Mo. Ct. App. 1975); Little Neck Community Ass'n v. Working Org. for Retarded Children, 52 A.D.2d 90, 383 N.Y.S.2d 364 (1976); Incorporated Village of Freeport v. Association for the Help of Retarded Children, 94 Misc. 2d 1048, 406 N.Y.S.2d 221 (Sup. Ct. 1977); Children's Home v. City of Easton, 417 A.2d 830 (Pa. Commw. Ct. 1980); Hopkins v. Zoning Hearing Bd., 423 A.2d 1082 (Pa. Commw. Ct. 1980).

173. The New York courts, unlike the New Jersey courts, require inore than the outward appearance of a single housekeeping unit in their classification of family-like aggregates. A Wisconsin court has distinguished between attempts "to duplicate the biological family" on the one hand, and atteinpts "to duplicate the family life style" on the other. Browndale Int'l, Ltd. v. Board of Adjustunent, 60 Wis. 2d 182, 205, 208 N.W.2d 121, 123 (1973), cert. denied, 416 U.S. 936 (1974). Browndale and a recent Ohio case, Garcia v. Siffrin Residential Ass'n, 63 Ohio St. 2d 259, 407 
some ideological values attach to the traditional family and the traditional family only, the functional family doctrine suggests that these ideological values are not goals that justify the use of the police power to regulate land use. These cases seem to illustrate the desire of some courts to limit zoning to the regulation of relatively tangible aspects of the urban environinent and the furtherance of more traditional objectives of the police power, such as those which largely motivated the first comprehensive zoning effort in New York City.

4. Mitigating Factors: The "Escape Hatches." Any scheme of legislative classification might, in the appropriate circumstances, be impugned for its rigidity. A zoning ordinance permitting no group of unrelated individuals to hive within its borders might appear to operate unfairly against a major sector of society, thus making the ordinance constitutionally infirm. Arguably, however, there are a number of devices and considerations that would mitigate the alleged rigidity of traditional-family ordinances and thereby aid thein in passing constitutional muster. For example, traditional-family ordinances almost invariably include an exception for a limited number of unrelated mdividuals living together in a lousekeeping unit. This exception has received a mixed reception in the courts. In a case considering an ordinance permitting groups related by a "domestic bond" other than birth or inarriage, one court observed that where "the zoning restriction does not totally exclude occupancy of persons unrelated by blood or inarriage ties from all type residential districts, the legislative classification does not deny equal protection."174 Most traditional-family ordinances limit the number of unrelated individuals permitted to occupy a dwelling. The zoning measure in Belle Terre set the limit at two. The Supreme Court did not consider this an unjustifiably arbitrary choice: "[E]very lime drawn by a legislature leaves some out that might well have been included. That exercise of discretion, however, is a legislative, not a judicial, function." 175 In contrast, a New Jersey court lield that a traditional-family ordinance unreasonably restricted the right of

N.E.2d 1369 (1980), cert. denied, 450 U.S. 911 (1981), suggest that a relevant consideration in determining whether a household is the functional equivalent of a family is the purpose for which the members have been brought together. The court in Browndale found that the primary purpose of the therapeutic homes at issue was commercial. The Garcia court concluded that the group home in question was established primarily for the care and training of its occupants. Consequently, the domestic units in both cases were not deemed to be families.

174. People v. Kalayjian, 76 Misc. 2d 1097, 1100, 352 N.Y.S.2d 115, 118 (Sup. Ct. 1973).

175. Village of Belle Terre v. Boraas, 416 U.S. 1, 8 (1974) (footnote omitted). The exception for unrelated imdividuals permitted Mr. Justice Douglas to distinguish Belle Terre from United States Dep't of Agriculture v. Moreno, 413 U.S. 528 (1973) (denial of foodstamps to households containing unrelated individuals is improper). See 416 U.S. at 8 n.6. Some commentators have 
unrelated people to share housekeeping facilities and found "no significant amelioration of such unreasonableness in allowing occupancy by two unrelated people." 176

Other devices which inject flexibility into the system-the variance and the special exception or conditional use permit-might appear to significantly lessen any alleged arbitrariness of a traditional-family ordimance. But the few cases on the subject suggest that the availability of a variance procedure will not adequately aineliorate the effect of an otherwise unconstitutional traditional-family ordmance. ${ }^{177}$ As one Supreme Court Justice said: "We have now passed well beyond the day when illusory escape hatches could justify the imposition of burdens on fundamental rights." 178 No case has yet fully considered the conditional use question, but the discretionary nature of the permit process could prove problematic when the identity of land users is so obviously at issue. ${ }^{179}$

If the chief argument against traditional-family ordinances is that they unfairly limit the liousing choices of unrelated groups, the availability of alternative lrousing for these groups in other districts within the municipality or the surrounding region may mitigate the alleged unfairness. The lower courts considered this issue in the Belle Terre case. Belle Terre, a small Long Island village, ${ }^{180}$ was zoned in its entirety for traditional families, with an exception for donnestic units con-

criticized the ease with which the Court reconciled Moreno and Belle Terre. See, e.g., Wilkinson \& White, supra note 91 , at 584-87.

176. Gabe Collins Realty, Inc. v. City of Margate City, 112 N.J. Super. 341, 349, 271 A.2d 430, 434 (App. Div. 1970).

177. See Moore v. City of E. Cleveland, 431 U.S. 494, 497 n.5, 511-13 (1977) (plurality); City of Santa Barbara v. Adamson, 27 Cal. 3d 123, 135-37, 610 P.2d 436, 443-44, 164 Cal. Rptr. 539, $546-47$ (1980) (en banc).

178. Moore v. City of E. Cleveland, 431 U.S. 494, 513 (1977) (Brennan, J., concurring). Apparently, East Cleveland had advised Mrs. Moore that she would probably receive a variance, but the legal-aid society lawyers representing her wished to test the constitutional issues and persuaded her not to apply for it. See R. Ellickson \& A.D. TARLOCK, supra note 53, at 894; $c f$. Brief for Appellce at 18, Moore v. City of E. Cleveland, 431 U.S. 494 (1977) (plurality) ("Relief, possibly with some stipulation(s) would probably have been granted.") (footnote omitted).

179. See, e.g., City of Chula Vista v. Pagard, 159 Cal. Rptr. 29, 39 (1979) (alleged that religious family group was "excluded by bureaucratic interposition from living in any zone in Chula Vista"), vacated, 115 Cal. App. 3d 785, 795-96, 171 Cal. Rptr. 738, 744 (1981) (vesting discretion in planning commission as to establishment of "group residence" created "infirmity" in conditional use permit system); see also City of Santa Barbara v. Adamson, 27 Cal. 3d 123, 134-35, 610 P.2d 436, 442-43, 164 Cal. Rptr. 539, 545-46 (1980) (en banc) (argument that lifestyle of unrelatcd households could be preserved by conditional use permit for boarding house not accepted). Similar distrust of administrative discretion appears in decisions discussing variances. See, e.g., Moore v. City of E. Cleveland, 431 U.S. 494, 512-13 (1977) (plurality).

180. Belle Terre contained approximately 220 homes and 700 inhabitants in a land area of less than one square mile. 416 U.S. at 2. 
sisting of two unrelated individuals. Six unrelated students attending a nearby university were residing together in one of the village's houses in violation of the zoning ordinance. To the federal district court, the fact that the students could either obtain similar housing in nearby communities or take up residence on campus where dormitory space was plentiful neant that "no substantial constitutional question [was] presented"181 because there was "no present threat exclusion froin Belle Terre would deny to the plaintiff students the right to hive as the group that they are."182 But a inajority of the court of appeals took a different view: to the appeals court, limiting the geographical scope of an unconstitutional ordinance did not niake the statute less objectionable. The nuajority noted that neighboring municipalities might adopt similar ordinances and that some had already done so. ${ }^{183}$

Expulsion fronl one's home is a serious sanction. ${ }^{184}$ Fairness, however, does not require unfettered choice: ${ }^{185}$ zoning has always limited dwelling choices and operated to prevent people from locating in particular sectors of a community. Furthermore, regional considerations have mcreasingly entered into judicial appraisals of zoning ordinances. ${ }^{186}$ In short, to recognize municipal autonomy as a worthwhile value, the availability of alternative housing should not be summarily rejected as a factor in assessing the validity of traditional-family ordinances. ${ }^{187}$

181. Boraas v. Village of Belle Terre, 367 F. Supp. 136, 148-49 (E.D.N.Y. 1972), affd, 416 U.S. 1 (1974).

182. Id. at 147; see also Moore v. City of E. Cleveland, 43 I U.S. 494, 550 (1977) (White, J., dissenting).

183. Boraas v. Village of Belle Terre, 476 F.2d 806, 817-18 (2d Cir. 1973), rev'd, 416 U.S. I (1974); see also Timberlake v. Kenkel, 369 F. Supp. 456, 468 (E.D. Wis. 1974), vacated and remanded, 510 F.2d 976 (7th Cir. 1975) ("This argument [that there is other housing available] is not persuasive because it assumes that the original classification was a rational one. . . . I have found that it was irrational, and an irrational classification is not saved because one can escape its irrationality by hiving elsewhere.").

184. See Doyle, Retirement Communities: The Nature and Enforceability of Residential Segregation by Age, 76 Mich. L. Rev. 64, 95 n.125 (1977).

185. See Heyman, Innovative Land Regulation and Comprehensive Planning, in THE NEw ZoNING, supra note 106, at 65 .

186. See, e.g., Southern Burlington Coumty NAACP v. Township of Mount Laurel, 67 N.J. 151, 336 A.2d 713, appeal dismissed and cert. denied, 423 U.S. 808 (1975); Blumstem, supra note 83, at 15-35; Developments in the Law-Zoning, supra note 11, at 1635-41. Regional considerations were used in the past as well, although at times to uphold the validity of unfairly restrictive municipal land use controls. See Burcltell, Listokin, \& James, Exclusionary Zoning: Pitfalls of the Regional Remedy, im New Dimensions of URban Planning: Growth Controls 36 (J. Hughes ed. 1974).

187. A number of cases appear to support this view. See, e.g., Palo Alto Tenants Union v. Morgan, 321 F. Supp. 908, 912 (N.D. Cal. 1970), affd per curiam, 487 F.2d 883 (9th Cir. 1973); City of Clula Vista v. Pagard, 159 Cal. Rptr. 29, 39 (1979), vacated, 115 Cal. App. 3d 785, 171 Cal. Rptr. 738 (1981); People v. Renaissance Project, Inc., 36 N.Y.2d 65, 70, 324 N.E.2d 355, 357, 364 


\section{The Avoidance of Abuses and the Balancing of Values.}

Although courts have at their disposal a multitude of tools with which to dissect traditional-family zoning ordinances, these tools should be used with restraint. Courts must balance important values when reviewing traditional-family ordinances: at the very least, a coinmumity's right to determine its own destimy unust be measured against an mdividual's interest im choosing his or. her own hifestyle. The cases reveal no unified policy of review. Solne courts champion the public interest; others, private rights. The preferable middle way should structure analysis of traditional-family ordinances so that judicial intervention inay prevent abuses. But this intervention should be neither haphazard nor insensitive to the value of local autonouny.

At times the approach of reviewing courts has caused two public interests to conflict: the public imterest in controlling population density opposes the public interest in maintaining the integrity of the fainily. As noted previously, both concerns have at least soine validity as zoning goals. ${ }^{188}$ For instance, one Supreme Court Justice has suggested that absolute density control-limiting the number of people allowed to hive in a smgle-family dwelling-is proper and potentially less intrusive than a traditional-family ordinance. ${ }^{189}$ But if such density controls threatened to split a family it should be appropriate to relax the restrictions, within the bounds of public health requirenents, so as to allow the family to live in one dwelling. Moore suggests that even the extended family has a favored constitutional position. Yet, is there a difference between an ordimance that permits any number of related individuals to live as a household but limits the number of unrelated persons who nray do so, and an ordinance that ties occupancy to available floor space but relaxes the standards to permit related individuals to reside together? 190 In their rusis to overturn traditional-family ordinances and suggest supposedly inore appropriate means to accomplish the desired ends, the courts sometimes appear to be the ones who are "burn[ing] the house to roast the pig."191

Furthermore, soine ends may be achieved by no ineans other than a traditional-family ordinance. The ideological goals associated with

N.Y.S.2d 885, 887 (1975); see also Burt, The Constitution of the Family, 1979 SuP. Cr. REv. 329, 390-91 (arguing that the availability of alternative housing in the metropolitan area should have been considered in Moore v. City of E. Cleveland, 431 U.S. 494 (1977)).

188. See supra text accompanying notes $56-58,127-40$.

189. See Moore v. City of E. Cleveland, 431 U.S. 494, 520 n.16 (1977) (Stevens, J., concurring); see also Village of Belle Terre v. Boraas, 416 U.S. 1, 19 (1974) (Marshall, J., dissenting).

190. See Town of Durham v. White Enters., 115 N.H. 645, 648, 348 A.2d 706, 708 (1975).

191. Larson v. Mayor of Spring Lake Heights, 99 N.J. Super. 365, 374, 240 A.2d 31, 36 (Law Div. 1968). 
the traditional family can only be promoted by limiting a residential district exclusively to legally and biologically related groups, with possible exceptions for small numbers of unrelated individuals. ${ }^{192}$ In addition, there are aspects of the community character of a single family neighborhood that cannot be preserved by conventional density, traffic, and other controls relating to physical aspects. ${ }^{193}$ Such abstract and intangible objectives have received little attention froin courts engaged in their own ends and means analyses.

Because zoning ordinances requiring that dornestic units be legally and biologically related can radically interfere with the lifestyle clooices of some, it seems appropriate to insist that municipalities present a factual basis for the legislative classification imposed in this sort of regulation. This suggests a departure from the usual judicial appraisal of zoning restrictions in two ways. First, local governing bodies would have the burden of justifying their regulatory action; in other words, the usual presumption of validity would be reversed, at least to some extent. ${ }^{194}$ Second, requiring that-the factual bases underlying a traditional-family ordinance be revealed would imply an interunediate level of substantive review: higher than the usual due process and first level

192. One commentator argues that for a community pursuing the ends that Belle Terre sought to achieve with its ordinance, "there exists no palatable alternative to bright-line distinctions between families and other groups. No system of individualized hearings could adequately predict which living units present substantial risks of community harm, nor could any such system avoid outrageous intrusiveness in gathering its information." Lupu, Untangling the Strands of the Fourteenth Amendment, 77 MiCH. L. REV. 981, 1053 (1979).

193. See Moore v. City of E. Cleveland, 431 U.S. 494, 539 n.9 (1977):

The appellant makes much of East Cleveland Housing Code $\$ 1351.03$ (1966), which prescribes a minimun habitable floor area per person; she argues that because the municipality has chosen to establish a specific density control the simgle-family ordinauce can have no role to play. It is obvious, however, that $\$ 1351.03$ is directed not at preserving the character of a residential area but at establishing minimum health and safety standards.

Id. (Stewart, J., dissenting) (emphasis added).

Professor Tribe suggests the sort of reasoning a municipality might employ in arguing that it required a traditional-family ordinance to preserve its character and that no less restrictive regulatory alternatives were available to it:

The government, moreover, may insist that . . . the very presence of significant numbers of student or other non-family groups (if one such group has a right to move $\mathrm{m}$, why not two? twenty?) will gradually alter the character of life in the community, not simply because of everyone's knowledge about what sorts of people live behind the drawn shades but because the entire fabric of cultural, econornic, and social existence mevitably responds to the tastes and preferences of those who make up any given population. Thus one might, for exainple, expect a change in the character of the entertainments shown at a neighborhood theatre after the composition of the neighborhood has changed; such collective changes cannot be avoided simply by looking the other way. Nor can they be reduced to any compendium of discrete harms avoidable, one by one, through less restrictive alternatives than zoning out identified types of persons.

L. TRIBE, supra note 171, at 983 (einphasis added).

194. See supra text accoinpanying notes 123-27. 
equal protection analysis, but somewhat lower than the compelling state interest test. ${ }^{195}$

By applying this standard, courts could ensure that a municipahity harbors no predominant bad motive-such as a desire to make life difficult for "alternative" families-in enacting a particular zoning scheine. Moreover, the burden of indicating the underlying motive would fall on the party best able to easily and accurately discharge that burden. Local governments would not, however, face the almost insuperable task of meeting the second tier of equal protection analysis or the brand of substantive due process review applied by some New Jersey courts in appraising traditional-family ordinances. ${ }^{196}$ In this way, the suggested standard respects the value of local autonomy.

Even if a municipality can justify the legislative classification found in a traditional-family ordinance with a fact-basis argument, such a regulation could still harbor the potential for abuse. For imstance, a large metropolitan area zoned entirely for traditional families might proinpt even the most enthusiastic supporter of local autonomy to balk. A court should, however, be more sympathetic to a similar regulation that provided places in the region for alternative families to reside in accommodations of acceptable quantity and quality. Even a variance or conditional use scheme, if it adopted adequately detailed objective standards for granting the remedy and was administered openly and fairly, might soften the effect of a city-wide traditional-family ordinance sufficiently to validate the ordmance. The availability of alternative housing should be a crucial factor in determining the validity or invalidity of a traditional-family ordmance. To argue otherwise seems infiexible and unnecessarily hostile to the idea of permitting a inunicipahity to determine its own destmy.

A local government can take this approach one step further by providing a plan for a balanced housing stock adequate for the needs of both traditional and non-traditional livimg groups. In turn, a plan for a balanced housing stock could form part of a larger coinprehensive plan for the cominunity. An appropriate comprehensive plan would not only address housing needs in terms of allotting adequate sites for both related and unrelated groups, but would also contain much of the factual material upon which the distinction between the related and unrelated groups was based.

A coinprehensive plan can incorporate each of the factors that a court should consider im reviewing a traditional-family ordinance: fact bases, availability of alternative housing, and planning for alternative

195. See supra notes 130-35 and accompanying text.

196. See supra notes 120-22, 134-35 and accompanying text. 
housing. Whether denominated due process, equal protection, or soine other standard of substantive review, an examination of single-family zoning by a court benefits from the application of a flexible conceptual framework relying upon these factors. Municipalities would also benefit froin adopting this framework as a guide to preparing and draftimg zoning for single-family districts. And as will be seen, this framework fits equally well with other varieties of zoning for direct social control-such as age-restrictive zoning.

\section{Zoning for Direct Social Control: Age Restrictions}

\section{A. Development of Age-Restrictive Zoning.}

Age-restrictive zoning ordinances authorize land users to live in a dwelling area, or exclude them, on the basis of their age. Such ordinances are a comparatively recent innovation. ${ }^{197}$ In 1965 a Connecticut court considered a zoning amendment creating "A Senior Citizen Planned Community District." 198 The ordinance, which required tracts of land containing at least 400 acres for such projects, inposed special occupancy restrictions:

[T] he occupancy of such a community shall be restricted to persons who are fifty years of age or over, subject to certain exceptions, such as a spouse under fifty years inarried to one over that age, children over eighteen years, residing with at least one parent over fifty years, and adults under fifty years if his or her presence is required to minister to an occupant over fifty years of age. ${ }^{199}$

The court noted that it had found "no precedent in Connecticut or elsewhere" for this type of zoning ordinance. 200 During the past decade, however, cases considering age-restrictive zoning have becoine more prevalent, although they are still relatively few in number. ${ }^{201}$ Appar-

197. The development of zoning provides an excellent example of the law's ability to evolve. As the urban environment has increased in complexity, the police power has expanded to meet the new legal needs. See R. Walker, The Planning Function In URban Government 50 (2d ed. 1950); Baker, The Constitutionality of Zoning Laws, 20 ILL. L. REV. 213, 242, 250 (1925).

198. Hinman v. Planning \& Zoning Coinm'n, 26 Conn. Supp. 125, 214 A.2d 131 (C.P. 1965).

199. Id. at $127,214 \mathrm{~A} .2 \mathrm{~d}$ at 132 .

200. Id. at 128,214 A.2d at 133 .

201. See, e.g., Bell v. Planning \& Zoning Comm'n, 174 Conn. 493, 391 A.2d 154 (1978); Shepard v. Woodland Township Comm. \& Planning Bd., 71 N.J. 230, 364 A.2d 1005 (1976); Taxpayers Ass'n v. Weymouth Township, 71 N.J. 249, 364 A.2d 1016 (1976), appeal dismissed and cert. denied, 430 U.S. 977 (1977); Campbell v. Barraud, 58 A.D.2d 570, 394 N.Y.S.2d 909 (1977); Apfelbaum v. Town of Clarkstown, 104 Misc. 2 d 371, 428 N.Y.S.2d 387 (Sup. Ct. I980). Age-restrictive ordinances authorizing the creation of retirement communities are probably more common than the small number of reported decisions considering them would suggest. See Shepard v. Woodland Township Coinm. \& Planning Bd., 71 N.J. 230, 236 n.4, 364 A.2d 1005, 1009 n.4 (1976). 
ently age-restrictive ordinances exemplify the increasing trend to employ zoning for direct social control.202

Age-restrictive zoning has occurred in connection with the estabhishment of planned communities designed specifically for the elderly. These projects, often called retirement communities, usually feature low density developments, are designed on a relatively large scale, and may consist of a variety of building types, including low- and even high-rise apartments, ${ }^{203}$ duplexes and simgle-family homes, ${ }^{204}$ and mobile hoines. ${ }^{205}$ They frequently incorporate such features as recreational and medical facilities, ${ }^{206}$ central dining areas, ${ }^{207}$ security

202. The pressures in this direction may be both demographic and market-related. In 1955 Professor Williams noted an mcrease in age segregation in the urban environment. See Williams, supra note 77, at 33I. It is worth noting, however, that Williams saw segregation of residential districts by age groups occurring because "most new areas are developed primarily for young married couples with young children." Id:; see also Taxpayers Ass'n v. Weymouth Township, 71 N.J. 249, 266-67, 364 A.2d I016, 1025-26 (1976) ("As a consequence of dechining birth rates and longer hife expectancies, the elderly are mcreasing both in absolute numbers and in relative proportion to the total population.") (citations omitted), appeal dismissed and cert. denied, 430 U.S. 977 (1977); Travalio, supra note 123, at 319. Commentators with both governmental and market perspectives now recognize that the elderly have special housing needs. See Taxpayers Ass'n v. Weynouth Township, 71 N.J. 249, 267-68, 364 A.2d 1016, 1026-27 (1976) (citing sources), appeal dismissed and cert. denied, 430 U.S. 977 (1977); Melman, Housing for the Aged-The Government Response: An Analysis of the Missouri Boarding House for the Aged Law, 8 URB. LAw. 123, 123-25 (1976). They realize that a critical shortage of appropriate housing exists. See Taxpayers Ass'n v. Weymouth Township, 71 N.J. 249, 272-73, 364 A.2d 1016, 1028-29 (1976) (citing sources), appeal dismissed and cert. denied, 430 U.S. 977 (1977). One result has been legislation at both the state and federal levels. See id. at 273, 364 A.2d at 1029; Maldimi v. Ambro, 36 N.Y.2d 481, 484-85, 330 N.E.2d 403, 406, 369 N.Y.S.2d 385, 389, appeal dismissed and cert. denied, 423 U.S. 993 (1975); Melman, supra, at 125-30 (description of federal legislative responses to the problem of housing for the elderly). Another response is the use of private agreements such as restrictive covenants or condominium agreements to exclude children from developments. See, e.g., Riley v. Stoves, 22 Ariz. App. 223, 526 P.2d 747 (1974); White Egret Condominium, Inc. v. Franklin, 379 So. $2 d 346$ (Fla. 1979); Shepard v. Woodland Township Comm. \& Planning Bd., 71 N.J. 230, 236 n.3, 364 A.2d 1005, 1009 n.3 (1976) (while litigation was pending, the effect of age-restrictive zoning ordinance was sought to be achieved through the use of restrictive covenants). The demand for developments restricted to the elderly is increasing. See, e.g., R. NELSON, ZoNING AND PROPERTY Rights 42-43 (1977); Doyle, supra note 184, at 64. For an account of how the residents of Sun City, Cahfornia, petitioned their local government for the creation of an age-restricted zone and the imposition of that classification upon their residential districts, see Holmes \& Brown, The Age Restricted Residence: Legitimate Exclusionary Zoning for the Future, 13 LoY. L.A. L. REv. 921 , 945-47 (1980).

203. See, e.g., Troy, Mich., Zoning Ordinance art. VI, $\$ \S 5.42(5), 5.45(6)$, reprinted in C. CRAWFORD, supra note 44, at 139.

204. See, e.g. , Elrod, Housing Alternatives for the Elderly, 18 J. FAM. L. 723, 740-41 (1979-80) (general description of retirement commumities).

205. See, e.g., Taxpayers Ass'n v. Weymouth Township, 71 N.J. 249, 364 A.2d 1016 (1976), appeal dismissed and cert. denied, 430 U.S. 977 (1977); Elrod, supra note 204, at 740-41.

206. See, e.g., Elrod, supra note 204, at 740-41.

207. See, e.g., Pioneer Trust \& Sav. Bank v. County of Cook, 49 Ill. App. 3d 630, 640, 365 N.E.2d 913, 918-19 (1977), rev'd, 71 Ill. 2d 510, 377 N.E.2d 21 (1978). 
systems, ${ }^{208}$ low-gradient walks, hand rails, and ramps. ${ }^{209}$ The occupancy restrictions in ordinances directed toward these projects also vary widely, but generally the minimum age for occupancy is at least fifty-two. 210 Such regulations often include exceptions for some persons who do not satisfy the minimum age requirement, such as spouses $^{211}$ or children above a certain age (usually eighteen). ${ }^{212}$ of course, some ordinances make no exception for under-age spouses ${ }^{213}$ and, with respect to children, limit the number ${ }^{214}$ or exclude them altogether. $^{215}$

Traditionally, local governments have treated homes for the aged and nursing hoines as disfavored uses and soinetimes have attempted

208. Id. at 640,365 N.E.2d at 919.

209. See, e.g., Bell v. Planning \& Zoning Comm'n, 173 Conn. 223, 224 n.1, 377 A.2d 299, 299 n.l (1977) (reproducing zoning amendment establishing elderly housing regulations).

210. See Elrod, supra note 204, at $\mathbf{7 4 2}$. For cases considering ordinances imposing an age minimun of fifty-two, see Shepard v. Woodland Township Comm. \& Planning Bd., 71 N.J. 230, 364 A.2d 1005 (1976); Taxpayers Ass'n v. Weyınouth Township, 71 N.J. 249, 364 A.2d 1016 (1976), appeal dismissed and cert. denied, 430 U.S. 977 (1977); Maryland-National Capital Park \& Planning Comm'n v. Rossinoor Corp., 265 Md. 267, 288 A.2d 898 (1972). For an ordimance specifying a minimum age of fifty-five, see Campbell v. Barraud, 58 A.D.2d 570, 394 N.Y.S.2d 909 (1977). For an ordimance specifying sixty-two, see Troy, Mich., Zoning Ordinance art. Il, \& 5.2 (79), reprinted in C. CRAWFORD, supra note 44 at 130 . At Ieast one ordinance specifies a lower himit: fifty years of age. See Himman v. Planning \& Zoning Comm'n, 26 Conn. Supp. 125, 214 A.2d 131 (C.P. 1965). Municipalities have in some instances adopted zoning measures that authorize retirement communities but do not include any minimum age requirement for occupancy. See, e.g., Maldini v. Ambro, 36 N.Y.2d 481, 330 N.E.2d 403, 369 N.Y.S.2d 385, appeal dismissed and cert. denied, 423 U.S. 993 (1975).

211. See, e.g., Taxpayers Ass'n v. Weymouth Township, 125 N.J. Super. 376, 379, 311 A.2d 187, 188 (App. Div. 1973) (ordinance required younger spouse to be 45 years of age), rev'd, 71 N.J. 249, 364 A.2d 1016 (1976), appeal dismissed and cert. denied, 430 U.S. 977 (1977); Campbell v. Barraud, 58 A.D.2d 570, 572, 394 N.Y.S.2d 909, 912 (1977) (no minimum age requirements for younger spouse).

212. See, e.g., Taxpayers Ass'n v. Weymouth Township, 125 N.J. Super. 376, 379, 311 A.2d 187, 188 (App. Div. 1973) (eighteeu), rev'd, 71 N.J. 249, 364 A.2d 1016 (1976), appeal dismissed and cert. denied, 430 U.S. 977 (1977); Shepard v. Woodland Township Comm. \& Planning Bd., 71 N.J. 230, 364 A.2d 1005 (1976) (nineteen); Campbell v. Barraud, 58 A.D.2d 570, 572, 394 N.Y.S.2d 909, 912 (1977) (nineteen); Holmes \& Brown, supra note 202, at $946 \mathrm{n} .91$ (quoting ordmance excluding anyone under eighteen years of age). But see Point Pleasant, N.J., Code ch. 109-54, \& 20 (1969), quoted in Note, Zoning for the Elderly and Family Rights, 23 CATH. LAW. 118, 129 n.83 (1978) (no age limit for childreu if at least one parent is above the age minimum). Sone age-restrictive ordinances admit any adult, whether related or not, if his presence is necessary to minister to an occupant over the age minimum. See, e.g., Hinman v. Planning \& Zoning Comm'n, 26 Conn. Supp. 125, 214 A.2d 13I (C.P. 1965); Campbell v. Barraud, 58 A.D.2d 570, 572, 394 N.Y.S.2d 909, 912 (1977); Manalapan, N.J., Ameudment to Zoning Ordinance no. 1, art. V (August 1970), quoted in Note, supra, at 119 n.11.

213. See Shepard v. Woodland Township Comm. \& Planning Bd., 71 N.J. 230, 234, 364 A.2d 1005, 1007-08 (1976).

214. See id. (limit of one child).

215. See Troy, Mich., Zoning Ordimance art. II, $\$ 5.2$ (79), reprinted in C. CRAWFORD, supra note 44 , at 130 . 
to exclude them from certam districts. ${ }^{216}$ The recent age-restrictive ordinances, however, seek to affirmatively provide for the elderly. ${ }^{217}$ Other community policies may conflict with this impulse. For example, a nuinber of states liave legislation that prohibits discrimination against children in rental and lease arrangenients. ${ }^{218}$ In sonie circumstances courts have looked to these provisions as expressing a public policy against unequal treatinent in liousnig between fanilies with children and those without. ${ }^{219}$ Nevertlieless, recent cases upholding agerestrictive zoning measures that permit the creation of retirement commumities have not considered this type of broad public policy ${ }^{220}$ and, $m$ practice, courts inay pay little heed to these statutes. ${ }^{221}$

Solne states also have general civil rights legislation prolibiting discrimination on the basis of age.222 In two recent cases upholding ordinances contaming minimunı age requirenıents, courts, by looking to inore specific legislative provisions dealing with housing and real estate that omitted such prohibitions and by recognizing the public policy of encouraging the construction of housing for the elderly, determimed that general statutory prohibitions against age discrimmation did not apply.223 Other states have enacted legislation that explicitly

216. See, e.g., Washington ex rel. Seattle Trust Co. v. Roberge, 278 U.S. 116 (1928); Women's Kansas City St. Andrew Soc'y v. Kansas City, 54 F.2d 1071 (W.D. Mo. 1931), rev'd, 58 F.2d 593 (8th Cir. 1932). See generally 2 N. WILLIAMS, supra note 9, $§ \S 58.11-15$.

217. For possible reasons behind this change in attitude, see supra note 202.

218. See O'Brieu \& Fitzgerald, Apartment for Rent-Children Not Allowed: The Illinois Children in Housing Statute-Its Viability and a Proposal for Its Comprehensive Amendment, $25 \mathrm{DE}$ PAUL L. Rev. 64, 66 n.11 (1975) (listing statutes); Note, Housing Discrimination Against Children: The Legal Status of a Growing Social Problem, 16 J. FAM. L. 559, 565-71 (1977-78) [hereinafter cited as Housing Discrimination Against Children].

Some municipalities have enacted ordmances restricting discrimination against children in rental housing, but the effectiveness of these ineasures is questionable. See Dunaway \& Blied, Discrimination Against Children in Renial Housing: A California Perspective, 19 Santa Clara L. REv. 21, 51 (1979). An extensive list of state and local legislation prohibiting discrimination in rental housing against families with children is provided in Note, Why Johnny Can't Rent-An Examination of Laws Prohibiting Discrimination Against Families in Rental Housing, 94 HARv. L. REv. 1829, 1829 n.4 (1981) [heremafter cited as Why Johnny Can't Rent].

219. See Duggan v. County of Cook, 60 Ill. 2d 107, 116-17, 324 N.E.2d 406, 411 (1975); Gilman v. City of Newark, 73 N.J. Super. 562, 591, 180 A.2d 365, 381 (Law Div. 1962); Boyd H. Wood Co. v. Finkelstein, 193 Misc. 315, 84 N.Y.S.2d 459 (Sup. Ct. 1948). Such statutes are not directly enforceable in a situation involving a sale rather than a rental. Riley v. Stoves, 22 Ariz. App. 223, 226-27, 526 P.2d 747, 750-51 (1974).

220. See Housing Discrimination Against Children, supra note 218, at 601-02.

221. See O'Brien \& Fitzgerald, supra note 218, at 86 (concluding that Illinois legislation is not viable).

222. Housing Discrimination Against Children, supra note 218 at 572-75.

223. See Taxpayers Ass'n v. Weymouth Township, 71 N.J. 249, 285 n.16, 364 A.2d 1016, 1035 n.16 (1976), appeal dismissed and cert. denied, 430 U.S. 977 (1977); Cainpbell v. Barraud, 58 A.D.2d 570, 572, 394 N.Y.S.2d 909, 913 (1977). 
recognizes the validity of age restrictions. ${ }^{224}$ In the vast majority of states, however, the legislature has not articulated a policy with respect to age restrictions on land use; as a consequence, the task of determining the vahidity of age-restrictive zoning has fallen upon the courts.

Interestingly, the wide variation of judicial opinion found on the question of the validity of traditional-family ordimances does not appear in similar appraisals of age-restrictive zoning. State courts noticeably hostile to traditional-family ordinances often support measures containing age restrictions and other related occupancy requirements. But though they generally uphold age-restrictive zoning, courts have noted that age-restrictive ordinances can unfairly exclude certain members of society from a coinununity.225 Some cases have suggested Ineans by which this abusive capability of such zoning might be minimized. These suggested safeguards are similar to the ones discussed in connection with traditional-family zoning, ${ }^{226}$ and their potential apphcability and effectiveness $i m$ the context of both types of zoning deserve further examination. First, however, age-restrictive zoning should be considered in terms of its goals and its ability to survive substantive review.

\section{B. Purported Goals of Age-Restrictive Zoning.}

Like traditional-family zoning ordinances, age-restrictive ordinances encouraging retirement colnununities seek to satisfy housmg needs both with respect to relatively intangible matters and with respect to inore traditional concerns involving physical aspects of the residential environment. One of the latter, long counted ainong the conventional purposes of zoning, is noise control. Resort commumities

224. For example, New Hampshire excepts from its prohibition of age discrimination "the sale or rental of dwellings which are [sic] pursuant to a plan for a retirement or similar community establishment limited to persons over a certain age, not less than forty-five years." N.H. REv. Stat. ANN. \& 354-A: 8(V-b)(d) (Supp. 1979); see also ARIz. Rev. StAT. ANn. \$§ 33-1317(B), 33303(B) (Supp. 1980); Why Johnny Can't Rent, supra note 218, at 1842 n.67 (citing other examples of similar legislation). See generally Comment, Neither Seen Nor Heard: Keeping Children Out of Arizona's Adult Communities Under Arizona Revised Statutes Section 33-1317(B), 1975 ARIz. ST. L.J. 813.

225. The courts also recognize that all zoning has an exclusionary aspect. See, e.g., Construction Indus. Ass'n v. City of Petaluma, 522 F.2d 897, 906 (9th Cir. 1975), cert. denied, 424 U.S. 934 (1976):

Practically all zoning restrictions have as a purpose and effect the exclusion of some activity or type of structure or a certain density of inhabitants. And in reviewing the reasonableness of a zoning ordimance, our imquiry does not terminate with a finding that it is for an exclusiouary purpose. We must determine further whether the exclusion bears any rational relationship to a legitimate state interest.

Id. (footnote omitted) (emphasis in original).

226. See supra text accompanying notes 194-96. 
have attempted to eradicate the boisterous behavior of groups of unrelated youths occupymg seasonal dwellings by enacting ordinances requiring legal and biological relationships in domestic units, 227 but retirement communities often desire to avoid the noise accompanying the presence of any younger individuals. As several cases note, the elderly wish to escape the "irritations from the boisterousness of young children and some older children."228

Retirement communities under age-restrictive zoning also often attempt to address the specialized housing needs of the elderly by incorporatimg design features that recognize the physical infirmities accompanying aging. Testimony in one case indicated that, among other things, the elderly desire more concentrated services and public transportation facilities. ${ }^{229}$ Other simpler adjustments include ramps, health care facilities, and recreation planning. 230

Another goal of age-restrictive zoning is to increase the quantity of suitable housing stock. ${ }^{231}$ The shortage of appropriate housing for the

227. See supra text accompanying notes 63-64.

228. Campbell v. Barraud, 85 Misc. 2d 97, 99, 376 N.Y.S.2d 380, 383 (Sup. Ct. 1975), modified, 58 A.D.2d 570, 394 N.Y.S.2d 909 (1977); see also, e.g., Flowers v. John Burnham \& Co., 21 Cal. App. 3d 700, 703, 98 Cal. Rptr. 644, 645 (1971) (landlord sought to limit children in its apartments because of their "independence, mischieviousness, boisterousness and rowdyism"); Franklin v. White Egret Condominium, Inc., 358 So. 2d 1084, 1090 (Fla. Dist. Ct. App. 1977) (condominium agreeinent excluding children under the age of twelve because young children "are noisy, distracting and frequently an imposition upon our neighbors"), aff', 379 So. 2d 346 (Fla. 1979); C. PerIN, supra note 16, at 120-21; Shepard v. Woodland Township Comm. \& Planning Bd., 71 N.J. 230, 245, 364 A.2d 1005, 1014 (1976).

229. Campbell v. Barraud, 85 Misc. 2d 97, 99, 376 N.Y.S.2d 380, 383 (Sup. Ct. 1975), modified, 58 A.D.2d 570, 394 N.Y.S.2d 909 (1977).

230. As one government publication noted:

Plans should include more and wider walkways with fewer stairs, an interior and exterior designed to permit easy social contact, provision for common rooms, short distances between buildings, easy refuse collection, little mamtenance, and well-highted walkways and halls.

In addition, housing designed for the elderly slould include such facilities as a central dining room, health care facilities and recreational facilities.

N.J. Office on Aging, A Community Guide: Housing New Jersey's Elderry 4 (1971), quoted in Taxpayers Ass'n v. Weymouth Township, 71 N.J. 249, 269, 364 A.2d 1016, 1027 (1976), appeal dismissed and cert. denied, 430 U.S. 977 (1977). For an example of an ordinance that mandates many of these features, see Bell v. Planning \& Zoning Comm'n, 173 Conn. 223, 224 n.1, 377 A.2d 299, 299 n.1 (1977); see also Pioneer Trust \& Sav. Bank v. Connty of Cook, 49 Ill. App. 3d 630, 639-40, 365 N.E.2d 913, 918-19 (1977) (description of retirement complex), rev'd, 71 Ill. 2d 510,377 N.E.2d 21 (1978). Relatively easy access to shopping is also important for the elderly. See Slrepard v. Woodland Township Comm. \& Planning Bd., 71 N.J. 230, 241, 364 A.2d 1005, 1011-12 (1970).

231. Although helping to ensure the availability of an adequate supply of housing does not generally appear as a purpose of zoning in state enabling legislation and was probably not foreseen as a necessary concern by the draftsmen of the inodel legislation, see R. LiNowEs \& $D$. ALLENSWORTH, THE STATES AND LAND-USE CONTROL 162 (1975), in recent years it has come to be thought of as a proper goal in the public regulation of land use. See, e.g., Southern Burlington 
elderly ${ }^{232}$ and the difficulty many in this age group encounter in atteinpting to satisfy their housing needs because of their often fixed and limited incomes ${ }^{233}$ is well documented. An age-restrictive ordinance considered in one case recited in its declaration of policy and purpose "the need for decent, safe and moderately priced housing for the elderly."234

Municipahties have also pursued larger fiscal goals through agerestrictive zoning. Local officials have candidly admitted that in adopting this sort of ordinance they "desire to obtain additional municipal revenues without placing concurrent demands upon locally financed governmental services."235 Retirement communities represent a fiscally advantageous use: they generate more tax revenues than charges on local services because of the absence of school-age residents. ${ }^{236}$ Most age-restrictive ordimances either wholly exclude children or admit only those above the age of public schooling. ${ }^{237}$

Other goals underlying age-restrictive zoning enactments resemble the traditional-family aims discussed previously. One ordinance, for instance, recited as its purpose in limiting occupancy by age the preservation of community character, specifically "the open agricultural character" of the district. A reviewing court held that the establishment of retireinent communities was consistent with this purpose. ${ }^{238}$ In another case, the court suggested that limiting the occupancy of a mobile home

County NAACP v. Township of Mount Laurel, 67 N.J. 151, 175, 178-80, 336 A.2d 713, 727-28, appeal dismissed and cert. denied, 423 U.S. 808 (1975).

232. See, e.g., Taxpayers Ass'n v. Weymouth Township, 71 N.J. 249, 272, 364 A.2d 1016, 1028-29 (1976) (citing sources), appeal dismissed and cert. denied, 430 U.S. 977 (1977).

233. Id. at $268-69,364$ A.2d at 1026 (citing sources).

234. Id. at $259,364 \mathrm{~A} .2 \mathrm{~d}$ at 1022 .

235. Id. at $290,364 \mathrm{~A} .2 \mathrm{~d}$ at $1038-39$.

236. See id. at 290, 364 A.2d at 1038-39; see also Housing Discrimination Against Children, supra note 218, at 564, 595-98. There is hittle question that schools are expensive: educational costs comprise up to seventy percent of most local budgets. Hughes, The Fiscal and Social Impact of Alternative Forms of Housing, in New Dimensions OF URBAN PlanNING, supra note 186, at 92. Thus, age minimums such as fifty-five are selected because people in this age group are "no longer primarily interested in a child-oriented family of their own." Campbell v. Barraud, 85 Misc. 2d 97, 100, 376 N.Y.S.2d 380, 383 (Sup. Ct. 1975), modified, 58 A.D.2d 570, 394 N.Y.S.2d 909 (1977).

237. See, e.g., Shepard v. Woodland Township Comm. \& Planning Bd., 71 N.J. 230, 364 A.2d 1005 (1976) (ordinance allowed one child of 19 years of age or over). Apparently one New Jersey municipality has gone to the extreme of developing direct social control zoning to ensure it is not deluged by school-age children: the municipality "actually limits occupancy of units in inultifamily buildings to one preschool-age child per unit and forbids any occupancy by school-age children." R. BABCocK \& F. Bosselman, supra note 11, at 9; see also Williams \& Norman, supra note 11 , at 488 n. 24 .

238. See Shepard v. Woodland Township Comm. \& Planning Bd., 71 N.J. 230, 233-34, 364 A.2d 1005, 1007 (1976). 
park to the elderly could substantially reduce the traffic that might otherwise result from this sort of development. ${ }^{239}$ Off-street parking requirements are often relaxed in housing developments for the elderly because this age group possesses significantly fewer automobiles. ${ }^{240}$ Other physical standards have been similarly reduced in recognition of the unique characteristics in the elderly's use of residential land. ${ }^{241}$ These various objectives for the most part address the physical aspects of the urban environment. Furthermore, they all involve relatively traditional zonimg concerns. But these ordinances also pursue more intangible, less traditional ends.

Supporters of age-restrictive zoning regulations often seek to provide an environment that meets the special social and psychological needs of the elderly. ${ }^{242}$ "Though special social and psychological needs of the elderly are perhaps less obvious than their physical needs," remarked one court, "they are no less real."243 Retirement communities have attempted to encourage friendship and social contact through their physical design. ${ }^{244}$ An age-honiogeneous resident population may also serve this end, because the elderly are less mobile and require "readily accessible companionship," or need help in adjusting to the "social and psychological effects of retirement."245 Age-honıgeneous communities may also foster a "sense of security" and reduce "the fear of criminal victimization."246 More simply, age-segregation is said to have a positive influence on the "niental well-being" and morale of the elderly. ${ }^{247}$

239. See Taxpayers Ass'n v. Weymouth Township, 71 N.J. 249, 279, 364 A.2d 1016, 1033 (1976), appeal dismissed and cert. denied, 430 U.S. 977 (1977).

240. See Nelson, Exclusionary Zoning on the Basis of Age, 28 LAND UsE L. \& Zonino Dio. 5 , 5 (No. 10 1976); McCrann v. Town Plan \& Zoning Comm'n, 161 Conn. 65, 282 A.2d 900 (1971). Iromically, neighboring residents who challenged one zoning ordinance authorizing a retirement community clanned that the proposed developinent would increase traffic in the neighborhood. Maldini v. Ambro, 36 N.Y.2d 481, 486, 330 N.E.2d 403, 406, 369 N.Y.S.2d 385, 390, appeal dismissed and cert. denied, 423 U.S. 993 (1975).

241. See Nelson, supra note 240 , at 5-6.

242. See, e.g., Shepard v. Woodland Township Comm. \& Planning Bd., 71 N.J. 230, 245, 364 A.2d 1005, 1014 (1976); Taxpayers Ass'n v. Weymouth Township, 71 N.J. 249, 269-70, 364 A.2d 1016, 1027 (1976), appeal dismissed and cert. denied, 430 U.S. 977 (1977); Cainpbell v. Barraud, 58 A.D.2d 570, 572, 394 N.Y.S.2d 909, 912 (1977).

243. Taxpayers Ass'n v. Weymouth Township, 71 N.J. 249, 269-70, 364 A.2d 1016, 1027 (1976), appeal dismissed and cert. denied, 430 U.S. 977 (1977).

244. See Shepard v. Woodland Township Comm. \& Planning Bd., 71 N.J. 230, 240 \& n.8, 364 A.2d 1005, 1011 \& n.8 (1976); see also Williams, supra note 77, at 321-22.

245. Taxpayers Ass'n v. Weymouth Township, 71 N.J. 249, 270, 364 A.2d 1016, 1027 (1976), appeal dismissed and cert. denied, 430 U.S. 977 (1977).

246. Id. at 271,364 A.2d at 1028.

247. See Shepard v. Woodland Township Comm. \& Planning Bd., 71 N.J. 230, 245, 364 A.2d 1005, 1014 (1976) (quoting commentator). 
The reported cases clearly indicate that ideological goals are considered to underlie age-restrictive zoning to a significant extent; a desire to meet the social and psychological needs of the elderly has been explicitly identified as a substantial regulatory notivation. In contrast, although there are strong suggestions that courts have associated ideological goals witl traditional-family ordinances, it is impossible to state positively that this lias occurred. Moreover, the purported goals of agerestrictive zoning seein startlingly specialized. They differ from other measures regulating plysical standards, and even froin traditionalfamily ordinances, to the extent that they focus on the welfare of a relatively narrow group. The next section explores how the judiciary has treated the various objectives of age-restrictive zoning.

\section{Substantive Review of Age-Restrictive Zoning.}

1. The Enabling Acts. As noted earlier, courts evaluate traditional-family ordinances alinost exclusively on constitutional grounds. ${ }^{248}$ In contrast, courts have, to a significant extent, assessed age-restrictive zoning on the basis of whether the legislation delegating the zoning power to the relevant municipality authorizes such neasures. This las occurred even under enabling statutes fashioned after the Standard State Zoning Enabling Act, which broadly grants power to zone "[f]or the purpose of promoting health, safety, norals, or the general welfare of the community." 249

The first case to consider age-restrictive zoning found that the measure exceeded the municipality's authority under the Enabling Act. In Hinman v. Planning \& Zoning Commission, ${ }^{250}$ a Connecticut court held that the state legislature liad authorized municipalities to adopt only regulations "designed for the benefit of all of the people of a commumity" and had not conferred the power to "zon[e] for classes of people." ${ }^{251}$ Later cases have also examined age-restrictive zoning in terms of the "general welfare." One reason for this is that age-restrictive zoning appears to promote the imterests of a relatively narrow group, and has consequently given rise to charges of "spot zoning." 252

248. See supra note 108 and accompanying text.

249. Standard Act, supra note $54, \S 1$.

250. 26 Conn. Snpp. 125, 214 A.2d 131 (C.P. 1965).

251. Id. at $128-29,214 \mathrm{~A} .2 \mathrm{~d}$ at 133 .

252. See, e.g., Taxpayers Ass'n v. Weymouth Township, 71 N.J. 249, 261-62, 364 A.2d 1016, 1023 (1976), appeal dismissed and cert denied, 430 U.S. 977 (1977); Campbell v. Barraud, 85 Misc. 2d 97, 98, 376 N.Y.S.2d 380, 382 (Sup. Ct. 1975), modified, 58 A.D.2d 570, 571, 394 N.Y.S.2d 909, 911-12 (1977). Factors which may betray the presence of spot zoning are set out in R. ELLICKsoN \& A.D. TARLOCK, supra note 53, at 241-42. In dismissing these claims of spot zoning courts have considered it significant that large tracts of land have been allocated for retirennent communities. 
The concept of the "general welfare" is open-ended; if "regulatory power may be exercised not only to stop harmful occurrences, but also to require actions that enhance the social, economic, and physical environment . . the potential scope of valid regulation is enlarged considerably."253 Over the years state courts and the Supreme Court have given expansive interpretations of the concept of the general welfare in land use cases. ${ }^{254}$ After reviewing various studies and reports on the housing and other social probleins of the elderly, the Supreme Court of New Jersey dismissed any notion that the age-restrictive zoning ordinance before it in Taxpayers Association v. Weymouth Township promoted the interests of too narrow a group; it noted that "the concept of the 'general welfare' im land use regulation is quite expansive, and encompasses the provision of housing for all categories of people, including the elderly."2s5 In this light, age-restrictive zoning may lielp advance the public welfare by "bringing about 'the greatest good of the greatest number." 256 Age-restrictive zoning cannot, however, be sustained on this rationale if it particularly burdens another group in the population, a possibility examined later in this article. 257

An issue underlying all zoning for direct social control, the distinction between the regulation of land use and the regulation of land users, has proved especially troublesome in the context of age-restrictive zoning. Initially, the lower courts in New Jersey invalidated ordinances miposing minimuin age requirements because the enabling legislation authorized only regulation of the physical aspects of land

See Campbell v. Barraud, 85 Misc. 2d 97, 99, 376 N.Y.S.2d 380, 382 (Sup. Ct. 1975), modified, 58 A.D.2d 570, 394 N.Y.S.2d 909 (1977). The court in Weymouth Township defined spot zoning as "the use of the zoning power to benefit particular private interests rather than the collective interests of the community." "General welfare" tests aim directly at this practice.

253. Heyman, supra note 185, at 45-46. Cf. Citizens' Zone Plan Conference, Chicago 26-27 (1920) (report of proceedings Dec. 16-17, 1919) (health includes the promotion of coinfort).

254. See e.g., Weymouth Township, 71 N.J. at 265, 364 A.2d at 1024 ("the term is inutable and reflects current social conditions"); see also Village of Belle Terre v. Boraas, 416 U.S. 1, 6 (1974); Berman v. Parker, 348 U.S. 26, 32-33 (1954). See generally I N. Williams, supra note 9, § 13.03, at 285 (notion of general welfare expands in accordance with the views of judges).

255. 71 N.J. at 275,364 A.2d at 1030 (einphasis in original) (footnote omitted); see also Shepard v. Woodland Township Comm. \& Planning Bd., 71 N.J. 230, 238, 364 A.2d 1005, 1010 (1976); Maldim v. Ambro, 36 N.Y.2d 481, 487, 330 N.E.2d 403, 407, 369 N.Y.S.2d 385, 391, appeal dismissed and cert. denied, 423 U.S. 993 (1975) ("meeting this comnunity shortage of suitable housing accommodations for its population, including an important segment of that population with special needs is such [a proper governinental] objective") (no minimum age requirement imposcd im ordinance); ABA ADvisORY COMMISSION ON HOUSING AND URBAN Growth, supra note 109, at 123.

256. E. FREUND, supra note 104, at 5.

257. See infra text accoinpanying notes 307-08. 
use. 258 The state Supreme Court, however, adopted a different position in Weymouth, ${ }^{259}$ concluding that "ordinances which regulate use by regulatimg identified users are not inherently objectionable."260 The court also noted that zoning need not be rigidly confined to the physical aspects of the urban environinent. 261 Instead, "ordinances adopted under the zoning enabling act must bear a real and substantial relationship to the regulation of land within the municipality."262

The Weymouth standard might imply that a zoning ordinance may not pursue exclusively ideological goals and must have soine relationship to the physical use of land. ${ }^{263}$ A more relevant inquiry is not whether wholly ideological objectives underlie a zoning ordinance, but whether such objectives involve legitimate government interests and whether the measure in question actually advances those interests. Perhaps the Weymouth test addresses this latter question as well, by requiring a municipality to show the fact bases underlying its ordinances. ${ }^{264}$ But the phrasing of the test-which also echoes constitutional standards requiring that an impugned regulation bear a rational relationship to a legitimate governmental objective-does not clearly require fact bases analysis. ${ }^{265}$

2. Equal Protection: Weynouth Township. Constitutional appraisal of age-restrictive zoning has, for the inost part, proceeded along lines of equal protection rather than substantive due process analy-

258. See Shepard v. Woodland Township Comm. \& Planning Bd., 135 N.J. Super. 97, 99, 342 A.2d 853, 855 (App. Div. 1975), rev'd, 71 N.J. 230, 364 A.2d 1005 (1976); Taxpayers Ass'n v. Weymouth Township, 125 N.J. Super. 376, 380-81, 311 A.2d 187, 189 (App. Div. 1973), rev'd, 71 N.J. 249, 364 A.2d 1016 (1976), appeal dismissed and cert. denied, 430 U.S. 977 (1977).

259. "[A]s a conceptual matter regulation of land use cannot be precisely disassociated from regulation of land users." 71 N.J. at 277, 364 A.2d at 1031 (emphasis in original). The same view was expressed in the companion case. See Shepard v. Woodland Township Comm. \& Planning Bd., 71 N.J. 230, 244-45, 364 A.2d 1005, 1013 (1976); see also I N. WilliaMs, supra note 9, \$13.05, at 289.

260. 71 N.J. at 277, 364 A.2d at 1031 (footnote omitted). The court relied on Maldini v. Ambro, 36 N.Y.2d 481, 487-88, 330 N.E.2d 403, 407-08, 369 N.Y.S.2d 385, 391-92, appeal dismissed and cert. denied, 423 U.S. 993 (1975).

261. 71 N.J. at 278,364 A.2d at 1032 .

262. Id at 264, 364 A.2d at 1024. A similar test was adopted in the companion case, Shepard v. Woodland Township Comm. \& Planning Bd., 71 N.J. 230, 243, 364 A.2d 1005, 1013 (1976).

263. See generally Developments in the Law-Zoning, supra note 11, at 1455-57. The problem with this explanation is that none of the cases cited as illustrations of the apphication of the new test considered a zoning restriction pursuing wholly ideological ends. In fact, none of the cited cases investigated the extent to which ideological goals may be served by a zoning measure enacted pursuant to state enabling legislation.

264. See id at 1456-57.

265. But cf. State v. Miller, 83 N.J. 402, 414-15, 416 A.2d 821, 827 (1980) (suggesting that court in Weymouth Township really had meant to require an examination of the factual bases of the municipality's action). 
sis. ${ }^{266}$ The most elaborate equal protection analysis in any age-restrictive zoning case appears in Weymouth. Using a conventional twotiered approach, the Weymouth court first considered whether the age restriction at issue infringed upon any "fundamental" right so as to trigger strict scrutiny. Noting that housing has not been deemed a fundamental right under the fourteenth amendment of the federal Constitution, ${ }^{267}$ the court moved on to other concerns. ${ }^{268}$ This rather curt treatment of the fundamental rights question stands in contrast to the extensive treatment of this issue by commentators ${ }^{269}$ and other judges. ${ }^{270}$ In Franklin v. White Egret Condominium, Inc., ${ }^{271}$ the plaintiffs challenged a condominiuin agreement excluding children under the age of twelve as a violation of the equal protection clause of the fourteenth amendment. The Florida District Court of Appeal found a number of fundamental rights involved: the right to travel, the right to marry, the right to procreate and the right to marital privacy. ${ }^{272}$ If a private agreement imposing an age limit impairs such rights, a fortiori a public zoning regulation imposing a similar requirenent would also be constitutionally infirm.

Most courts have resisted the claim that any sort of zoning might infringe the constitutionally protected right to travel. ${ }^{273}$ A inajority of the Supreme Court summarily dismissed the right to travel claim made in the attack on the traditional-family ordmance that was considered in

266. Substantive due process considerations have not figured largely in judicial appraisals of age-restrictive zoning. The decision of the Supreme Court of New Jersey in Weymouth Township demonstrates this: the court held that the suit's due process claim was "hittle more than a restatement" of the equal protection challenge. 71 N.J. at 288, 364 A.2d at 1037. This passage of the opinion aptly demonstrates how, conceptually speaking, the two branches of constitutional substantive review have been closely associated; see also Travalio, supra note 123, at $310 \mathrm{n} .112$. It is evident that the concepts of substantive due process and equal protection of the laws were also closely associated in Shepard $v$. Woodland Township Comm. \& Planning Bd, the companion case to Weymouth Township. See 71 N.J. at 247, 364 A.2d at 1015.

267. See Lindsey v. Normet, 405 U.S. 56 (1972).

268. Riley v. Stoves, 22 Ariz. App. 223, 228 n.2, 526 P.2d 747, 752 n.2 (1974), reached a similar conclusion in considering a restrictive covenant that limited residence im a subdivision to residents above a certain age. But see Adrian Mobile Home Park v. City of Adrian, 94 Mich. App. 194, 288 N.W.2d 402 (1979) (age-restrictive provision in special use permit invalidated).

269. See, e.g., Doyle, supra note 184, at 76-79, 89-97; Travahio, supra note 123; Comment, supra note 224, at 821-31; Note, supra note 212.

270. See Franklin v. White Egret Condominium, Inc., 358 So. 2 d 1084 (Fla. Dist. Ct. App. 1977) (age restrictive condominium agreement), affd, 379 So. $2 \mathrm{~d} 346$ (Fla. 1979).

271. Id. (constitutional issues apparently arising pursuant to state action theory).

272. 358 So. $2 \mathrm{~d}$ at 1088 . In denying a petition for rehearing the court indicated that a plethora of fundamental rights were infringed by the age restriction. The "panoply of rights associated with family life" were again enumerated and in greater detail, but this time the right to travel was added to the list. Id. at 1089-90.

273. See Doyle, supra note 184 , at $76-78$. 
Belle Terre. ${ }^{274}$ The attitude of the courts is understandable. All zoning regulations to some extent interfere with a person's right to travel and settle where he wishes; recognizing the right to travel argument could subject all land use controls to the second tier of equal protection scrutiny with its concomitant compelling state interest test-an ordeal that few ordinances could survive. ${ }^{275}$

The argument that age restrictions interfere with the bundle of rights associated with family life is more troublesome. The Supreine Court's careful treatinent of the unique traditional-family ordinance struck down in Moore v. City of East Cleveland ${ }^{276}$ indicates the degree of constitutional solicitude that may attach to the family. A number of commentators have noted that an age-restrictive zoning ordinance might exclude a family from an area because one or more of the family members fails to meet the age minimuın. ${ }^{277}$ Nevertheless, when the age-restrictive condominium agreement at issue in the Franklin case finally came before the Supreme Court of Florida, Moore presented no barrier to such land use schemes. ${ }^{278}$ In distinguishing Moore, the court appeared to be influenced by the limited geographic scope of the agesegregated community. 279 The significance of spatial factors in determining whether age-restrictive zoning is being einployed in an abusive fashion is a matter which will be taken up more extensively in due course. ${ }^{280}$

In Weymouth, the New Jersey Supreine Court also addressed the question of whether the legislative classification of age restriction involved a "suspect" criterion, which would trigger lieightened scrutiny under the fourteenth aniendment. It concluded that age is not a suspect

274. Village of Belle Terre v. Boraas, 416 U.S. 1 (1974).

275. See Associated Home Builders of the Greater Eastbay, Inc. v. City of Livermore, $18 \mathrm{Cal}$. 3d 582, 602-04, 557 P.2d 473, 484-85, 135 Cal. Rptr. 41, 52-53 (1976); Comment, Zoning, Communes and Equal Protection, 1973 URB. L. ANN. 319, 324; cf. L. TRIBE, supra note 171, at 955-56 (qualitative as opposed to quantitative land use controls should be immune to challenge on right to travel basis so long as they do not discriminate against new residents).

276. 431 U.S. 494 (1977) (plurality). See generally Developments in the Law-The Constitution and the Family, 93 HARv. L. REv. 1156, 1161-97 (1980).

277. See, e.g., Doyle, supra note 184, at 89-97.

278. See White Egret Condominium, Inc. v. Franklin, 379 So. 2d 346, 351 (Fla. 1979) ("We reject the view that Moore v. City of East Cleveland absolutely prohibits this type of limitation. We note that Congress has established age limitations in recognizing the need for senior citizen lousing by including an age minimum of sixty-two years for occupancy of ccrtain housing developments.") (citations omitted).

279. Id. at 351 ; see also Travaho, supra note 123, at 315. But see Doyle, supra note 184, at 95 n.125.

280. See infra text accompanying notes $341-46$. 
criterion. ${ }^{281}$ Although a relatively early case found age along with "race, color, creed or physical condition" 282 an irrelevant zoning consideration, later cases dealing specifically with age-restrictive ordinances have, like the court in Weymouth, specifically held that age is not a suspect criterion. One case distinguishes old age froin the suspect classifications because of the changeability of a person's age. ${ }^{283}$ Reahistically speaking, however, age is a relatively immutable characteristic, not significantly different at a given point in time from a classification like race. ${ }^{284}$

Other grounds justify distinguishing age restrictions from the type of classification contained in a racial segregation ordinance. Suspect criteria turn on more than the mere immutability of a characteristic. ${ }^{285}$ In the context of zoning for the elderly, the minimuin age requirement should be analyzed both from the point of view of the young people excluded by the limitation and from the standpoint of the elderly who fall within the restriction. The young people excluded froin a retirement community by an age-restrictive ordmance are generally neither a mimority nor politically powerless, nor do they have a history of unequal treatment in regard to housing. Thus, it is difficult to argue that the age restriction is a suspect classification because it unfairly burdens this group. ${ }^{286}$ From the viewpoint of the elderly who ineet the minimum age requirement, the ordmance appears beneficial to their interests. Indeed, one court described an ordinance establishing a

281. 71 N.J. at 281-82, 364 A.2d at 1034 (citing Massachusetts Bd. of Retirement v. Murgia, 427 U.S. 307 (1976) and other cases).

282. Central Management Co. v. Town Bd., 47 Misc. 2d 385, 387, 262 N.Y.S.2d 728, 731 (Sup. Ct.), affd, 24 A.D.2d 881, 264 N.Y.S.2d 1011 (1965).

283. See Maldini v. Ambro, 36 N.Y.2d 481, 488, 330 N.E.2d 403, 408, 369 N.Y.S.2d 385, 392 ("'Senior citizenship' may be more appropriately regarded as a stage in life withm the normal expectancy of most people than as an unalterable or obstinate classification like race . . religinn or economic status.") (citations onitted), cert. denied, 423 U.S. 993 (1975); see also Campbell v. Barraud, 58 A.D. 2d 570, 572, 394 N.Y.S. 2d 909, 912 (1977) ("Age is not a 'suspect' criterion and old age, or senior citizenship, merely 'marks a stage that each of us will reach if we live out our normal span.'") (quoting Massachusetts Bd. of Retirement v. Murgia, 427 U.S. 307, 313-14 (1976)); Travalio, supra note 123, at 322.

284. See Doyle, supra note 184, at 75 n. 43 ("In one sense, of course, age is mutable, since everyone who enjoys a normal lifespan will experience old age. But in other ways age is immutable. No one can, at any given moinent, change his age. And no one who is old can become young agani.").

285. See Weymouth Township, 71 N.J. at 281 n.15, 364 A.2d at $1034 \mathrm{n} .15$; Developments in the Law-Equal Protection, supra note 130, at 1124-27.

286. See Doyle, supra note 184 , at 75 ; see also Travaho, supra note 123 , at 329 . It is possible, however, that in the appropriate circumstances age-restrictive zoning could have an exclusionary effect which would qualify somewhat the analysis in the text, even if a suspect classification would not thereby be created. See infra notes 307-09 and accompanying text for a discussion of the exclusionary potential of age-restrictive zoning. 
retirement community district as an action "to correct social and historical patterns of housmg deprivation."287 Hence, key elements of a suspect classification are absent. ${ }^{288}$

Having determined that the zoning regulations at issue in Weymouth imphicated neither fundamental rights nor suspect criteria for purposes of fourteenth amendment analysis, the court applied the first level of equal protection scrutiny. This required the parties challenging the age-restrictive zoning to prove that it lacked a rational relationship to a legitimate state objective. The Weymouth plaintiffs failed to discharge this burden. Weynouth Township's choice of fifty-two as the minimum age for residency was somewhat arbitrary, but the court asserted that this was "necessarily" so, because "[a]ny choice of a specific figure mevitably excludes soine persons who miglit plausibly be adinitted and includes others who might plausibly have been excluded."289 Citing the Supreme Court's decision in Belle Terre, the court characterized the choice of a minimum age as a legislative determination "which ought not be disturbed by the judiciary unless it exceeds the bounds of reasonable choice."290 Furthermore, the imposition of appropriate age

287. Maldini v. Ambro, 36 N.Y. 2d 481, 485-86, 330 N.E. 2d 403, 406, 369 N.Y.S. 2d 385, 390, appeal dismissed and cert. denied, 423 U.S. 993 (1975); cf. Travalio, supra note 123, at 322 ("Agesegregated housing looks more like a societal recognition that a particular segment of the society has special needs that can only be met in a certain way, rather than smacking of political repression.").

288. The same considerations would of course not apply to an age-restrictive ordinance that sought to exclude the elderly. See Travalio, supra note 123, at 324; cf. Weymouth Township, 71 N.J. at 285, 364 A.2d at 1036 (Pursuant to the New Jersey constitution, it has been "held that age, at least where the classification burdens the young rather than the old, is not a 'suspect' criterion."). But see Apfelbaum v. Town of Clarkstown, 104 Misc. 2d 371, 420 N.Y.S.2d 387 (Sup. Ct. 1980) (denying plaintifi's motion for summary judgment declaring unconstitutional zoning provisions that required age-restricted developinents for the elderly to be limited in size and dispersed throughout the cominunity. The court seeined to be influenced by the fact that the challenged provisions were part of the municipality's coinprehensive zoning plan).

289. 71 N.J. at 284,364 A.2d at 1035 .

290. Id. at 284,364 A.2d at 1035 . The courts have almost invariably found a sufficient relationship between miniunum age requirements and the purported ends of zoning for the elderly. In a New York case, for example, the court found that the specific age-restriction was "essential to the achievement of the purpose of the planned retirement commumity ordinance, and its rational application" because otherwise there would be no guarantee that the group for which the honsing had been designed would occupy the development. Cainpbell v. Barraud, 58 A.D.2d 570, 572, 394 N.Y.S.2d 909, 912 (1977) ("It is illogical to encourage the construction of housing geared to the specialized needs of the elderly and then prohibit its exclusive use by such group. Moreover, occupancy restrictions of this nature also ensure that all of the origimal comprehensive plannimg and effort will not go for naught after the development has become fully operational."); see also Shepard v. Woodland Township Comm. \& Planning Bd., 71 N.J. 230, 246, 364 A.2d 1005, 1014 (1976). Commentators liave noted that without minimum age requirements, the elderly might lose out in a competition with "[y]oung couples, simgles, and students [who] will also gravitate toward this type of small, low-cost housing." Nelson, supra note 240, at 6; see also Note, Weymouth Township: Age Restrictions in Zoning, 31 ARK. L. REv. 707, 718 (1978). Moreover, if the occu- 
restrictions appears to be the most effective means of achieving goals of retirement commumities.

Having completed its federal equal protection clause review, the court analyzed the Weymouth age restriction pursuant to the principles of equal protection ensconced in the state constitution. The court ultimately concluded that the ordinances would survive even close judicial scrutiny under the state constitution, because the legislative classification was "based upon real factual distinctions, and also [bore] a real and substantial relationship to the ends which the municipahty [sought] to accomplish by that classification."291 The court's discovery of factual grounds for the challenged age restrictions tends to explain the contrastingly aggressive stance that the New Jersey court has displayed in reviewing traditional-family ordmances, where it evidently has been unable or unwilling to make a similar finding witl respect to the definitions of "family" contained in those regulations. Furtlierinore, as a passage in the companion case to Weymouth, Shepard v. Woodland Township Committee \& Planning Board ${ }^{292}$ illustratcs, the court consciously wished to circumscribe its review of age-restrictive measures:

[I]t is a major question to decide whether the aged should live in special segregated areas, or scattered annong the general population; a decision on this is likely to be phrased in terms of a land-use decision. Why should the courts invoke judge-made policy to preclude responsible local officials froin implementing such policies?293

pancy of retirement communities was not limited to the elderly, the relaxation of physical standards, such as off-street parking requirements, which is often permitted for such developments, would no longer be appropriate. See, Nelson, supra note 240, at 5-6.

291. 71 N.J. at 287, 364 A.2d at 1037. At another poimt in the opimion the court admits that it could not be said that the age limitation of fifty-two was "unreasonable or without a factual basis." Id. at 284, $364 \mathrm{~A} .2 \mathrm{~d}$ at 1035. In support of this assertion the court pointed out that many persons experience a decline in net income at this age, that the median ages at which men and women become grandparents are fifty-seven and fifty-four respectively, and that Americans increasingly retire in their fifties. Id. at 284-85, $364 \mathrm{~A} .2 \mathrm{~d}$ at 1035 .

292. 71 N.J. 230, 364 A.2d 1005 (1976). The ordinance considered in Shepard imposed an occupancy limit of three people in any residential unit. This numerical restriction was not keyed to available floor space, or some other physical standard, as the court suggested would be appropriate in the course of overturning traditional-family ordimances, see, e.g., State v. Baker, 81 N.J. $99,110,405$ A.2d 368, 373 (1979), nor did the Shepard court require the municipality to justify the need for the occupancy restriction, see Doyle, supra note 184, at 81 n.70 ("Neither the New Jersey Supreme Court nor the courts below addressed the issue of how the restriction on number of residents promoted the welfare of elderly housing consumers."); $c f$. Molino v. Mayor of Glassboro, 116 N.J. Super. 195, 204, 281 A.2d 401, 405-06 (Law Div. 1971) ("There is also a right to live as a family, and not be subject to a limitation on the number of members of that family in order to reside any place. Such legal barriers would offend the equal protection mandates of the Constitution.").

293. Shepard v. Woodland Township Comm. \& Planning Bd., 71 N.J. at 248, 364 A.2d at 1015-16 (emphasis deleted) (quoting 1 N. WILliaMs, supra note $9, \S 1.11$ at 22). It would appear that Professor Williams disagrees with the manner in which his treatise was cited: "The language 
In examining traditional-family ordinances, the New Jersey courts imquire whether each non-related household excluded from a residential district by the particular definition of "family" would in fact display the undesirable characteristics of such living umits generally. Because not all of the unrelated groups excluded by a traditional-family ordinance exhibit the purportedly unwanted qualities, the New Jersey courts have often struck down such zoning restrictions as overbroad. ${ }^{294}$ But when confronted with age-restrictive ordinances, the same courts have not inquired whether all of those excluded would have been undesirable residents from the viewpoint of the proposed retirement community. Instead, the courts have ignored the individuality of excluded persons and have recited principles of judicial restraint, leaving legislative line-drawing to elected officials. In the end, the attitudes of New Jersey's courts, and the courts of at least one other state, ${ }^{295}$ seeun inconsistent. This suggests at least two possible approaches to zoning for direct social control. Parallelling this choice of attitudes, the expansion of the police power with respect to traditionalfamily zoning lias been halted in a number of states while its scope may still be widening in regard to age segregation in housing.

\section{The Non-Elderly Who Wish to Exclude Children: "Adult-Only" Developments.}

Children have been described as "a lightning rod of social friction."296 Understandably, the elderly have often desired to avoid youthful neighbors through the creation of retirement communities. But non-elderly adults have also displayed a desire to live apart from children, "reflected in the skyrocketing number" of housing complexes now prohibiting children as residents. ${ }^{297}$ Various commentators liave recognized that younger adults may have legitimate reasons for wanting to live in a child-free environment and a legitimate right to pursue

omitted . . . makes it clear that this passage was arguing in favor of heterogeneity, not hounogeneity and segregation." 2 N. WILliams, supra note $9, \S 50.16$, at 50 n. 111.55 (1981 Supp.).

294. See, e.g., State v. Baker, 81 N.J. 99, 405 A.2d 368 (1979); Kirsch Holding Co. v. Borough of Manasquan, 59 N.J. 241, 281 A.2d 513 (1971).

295. There is a similar unevenness of approach in the manner in which New York courts have dealt with traditional-family ordinances and age-restrictive zoning. Compare Group House v. Board of Zoning \& Appeals, 45 N.Y.2d 266, 380 N.E.2d 207, 408 N.Y.S.2d 377 (1978) and City of White Plains v. Ferraioli, 34 N.Y.2d 300, 313 N.E.2d 756, 357 N.Y.S.2d 449 (1974) with Campbell v. Barraud, 58 A.D.2d 570, 394 N.Y.S.2d 909 (Sup. Ct. 1977).

296. C. PERIN, supra note 16 , at 120.

297. See Housing Discrimination Against Children, supra note 218, at 561; see also R. NELSON, supra note 202, at 42-43; Holmes \& Brown, supra note 202, at 948-49 \& n.97; Why Johnny Can'? Rent, supra note 218, at 1829, 1835. 
this objective, at least by means of private agreement. 298 On the other hand, in Molino v. Mayor of Glassboro 299 a lower New Jersey court held an attempt to exclude children indirectly by means of zoning restrictions invalid. Glassboro sought to discourage families with children from locating within its borders by sharply curtailing the nuinber of bedrooms permitted in apartment units. The zoning ordmance provided that at least seventy percent of all units could have no more than one bedroom and imcluded other provisions designed to exclude families with children. The town had adopted the ordinance with the avowed fiscal motive of limiting its number of school-age children so as to reduce education costs and the concomitant burden on local tax revenues.

The Molino court might not have overturned the ordimance so readily had it affirmatively provided for the adults in the municipality who wisled to live in a child-free environinent. Such an ordmance, limited in geographic scope and promoting a physical design suitable to the social and other needs of younger adults, would be similar to agerestrictive zoning for retirement communities. ${ }^{300}$

Cases dealing with restrictive covenants and condominium agreements provide the closest analogy to this possibility. White Egret Condominium, Inc. v. Franklin, ${ }^{301}$ for example, involved a condoninium agreement prohibiting residency by children under the age of twelve.

298. "Adults who wish to hive in . . . adult-only housing developments . . . also have constitutional and statutory rights which inust be respected." Dunaway \& Blied, supra note 218, at 50; see also Housing Discrimination Against Children, supra note 218, at 570, 606; O'Brien \& Fitzgerald, supra note 218, at 89; Why Johnny Can't Rent, supra note 218, at 1839 ("Restrictions on child discrimination also infringe the imterests of renters who desire to live apart from children. . . . [T]he age classifications used by most landlords are not arbitrary and should, if possible, be respected.") (footnote omitted).

299. 116 N.J. Super. 195, 281 A.2d 401 (Law Div. 1971). But see Malamar Assocs. v. Board of County Comm'rs, $260 \mathrm{Md}$. 292, 272 A.2d 6 (1971) (bedroom restrictions upheld as a valid means of controlling density).

300. The two types of zoning might be distinguished, however, on the grounds that unhke the elderly, younger adults are not politically and economically weak, have not been historically disadvantaged when it comes to housing, and, in reahty, do not have housing "needs" but have something more on the order of housing "preferences." But $c f$. the testimony of the plaintiff in a case upholding a restrictive covenant limiting the use of lots in a subdivision to persons 21 years of age and older, suggesting why an eligible resident might seek out sucl an environment for bona fide health reasons:

In the first place we searched for quite some tine to find an adult area that suited us; was quiet especially for my wife in her condition. Two specialists in California advised her due to her condition to move into a quiet area. She has a nervous condition and an arthritic condition. So the best place we figured out to move for her benefit would be to move to Arizona. And we searched in many places around here and due to these restrictions and being away and quiet this was our number one choice for residing here.

Riley v. Stoves, 22 Ariz. App. 223, 226, 526 P.2d 747, 752 (1974).

301. 379 So. 2d 346 (Fla. 1979), affg 358 So.2d 1084 (Fla. Dist App. 1978). 
Admittedly, the restriction was not a zoning ordinance enacted under the police power, but rather a private agreement entered into by eacli of the owners in the condominium developinent. ${ }^{302}$ But because theories of state action can subject private restrictions on land use to the requirements of the fourteenth amendment, ${ }^{303}$ the review of the private age restrictions parallels the scrutimy that the same restrictions would have received if contamed in zoning ordinances. By upholding such restrictions, the cases suggest that age-restrictive zoning for the nonelderly adult might encounter a less rocky road in the course of judicial appraisal than might, at first, be thought. ${ }^{304}$

Furthermore, at least one jurisdiction already deems the provision of child-free housing for adults a legitimate state interest. An Arizona statute makes it a criminal offense for a person to rent or lease his property im violation of a restrictive covenant against the sale of such property to persons having a child or children living witl them, or to rent to persons with children when his property lies within a subdivision designed, advertised, and used as an exclusively adult subdivision. 305 This legislation allows the creation of land use controls, functionally equivalent to zoning ordinances, excluding children froin residential areas and raises similar constitutional issues. ${ }^{306}$ The Arizona legislation aptly deinonstrates how the perceived scope of the police power in this area contmues to expand, and shows that regulatory goals will be-

302. See id. at 350; see also Riley v. Stoves, 22 Ariz. App. 223, 226-27, 526 P.2d 747, 750-51 (1974).

303. See Barrows v. Jackson, 346 U.S. 249 (1953); Shelley v. Kraemer, 334 U.S. 1 (1948); cf. L. TRIBE, supra note 171, at 978 ("judicial enforcement of an anti-commune covenant would probably lave to meet the same constitutional tests as those applicable to [a traditional family] ordinance") (footnote omitted); Note, Exclusionary Zoning and Equal Protection, 84 HARv. L. REv. 1645,1669 (1971) ("Restrictive covenants covering large areas thus verge so closely on being zoning ordinances that courts should be willing to view them as state action, and apply the same standards of equal protection suggested here for zoning ordin ances."). But see Doyle, supra note 184, at 97-105 (questioning whether state action theory apphable to imposition of private age restrictions); Travalio, supra note 123, at 325-31 (assessing whether state action theory applicable to age-restrictive covenants); id. at 332-34 (discussing applicability of state action theory to condominium rules).

304. Cf. Why Johnny Can't Rent, supra note 218, at 1839 n.60 (suggesting that a claim that child exclusion is unconstitutional is unlikely to succeed).

305. See ARLz. Rev. Stat. ANN. \& 33-1317(B) (Supp. 1981):

No person shall rent or lease his property to another in violation of a valid restrictive covenant against the sale of sucl property to persons who have a child or children living with them nor shall a person rent or lease his property to persons who have a child or children living with thein when his property lies within a subdivision whicls subdivision is presently designed, advertised and used as an exclusive adult subdivision. A person who knowingly rents or leases his property in violation of the provisions of this subsection is guilty of a petty offeuse.

See also ARIZ. Rev. StAT. ANN. § 33-303(B) (Supp. 1981).

306. See generally Comment, supra note 224. 
come increasingly sophisticated as the particular housing preferences of discrete sectors of the population receive legislative recognition.

\section{E. The Potential for Abuse and Methods of Avoiding It.}

1. The Potential for Abuse. In dealing with agc-restrictivc zoning authorizing retirement communities, some courts have expressed the fear that local governments will so strongly desire to achieve fiscal benefits that they will enact age-restrictive zoning for exclusionary purposes. "To put it bluntly," remarked one court, "a inunicipality could so regulate its zoning districts as to virtually exclude all but senior citizens, high incoine younger families, and industrial and commercial users, thereby ensuring the benefits of a large tax base." 307 As additional cause for concern, retirement communities appear to serve mostly semi-affluent whites. ${ }^{308}$

In spite of these dangers, courts have not struck down age-restrictive ordinances on the basis of their potential or actual exclusionary impact, largely because the parties objecting to the regulations have not pressed such theories. ${ }^{309}$ Nevertheless, the cases have implied a method for avoiding the exclusionary potential of age-restrictive zoning for the elderly. They have also provided some mdication of how to ensure that the legislative classifications imposed in these ordinances are not in theinselvcs abusive. This section examines these safeguards-safeguards previously suggested in the section on traditionalfamily zoning.

2. Fact Bases. In a recent opinion, the Supreme Court of New Jersey described the analysis earlier einployed in Weymouth to cnsure that ordinances adopted under the enabling act bear a real and substantial relationship to the regulation of land within the inunicipality:

307. Campbell v. Barraud, 58 A.D.2d 570, 573, 394 N.Y.S.2d 909, 913 (1977); see Shepard v. Woodland Township Comm. \& Planning Bd., 71 N.J. at 248-49, 364 A.2d at 1016; Weymouth Township, 71 N.J. at 288-96, 364 A.2d at 1037-42. The exclusionary potential of senior citizen zoning was recognized in the message accompanying the New Jersey Governor's veto of a state bill exphicitly authorizing age-restrictive zoning. The message is quoted in Weymouth Towns/ip. Id. at 291-92, 364 A.2d at 1039. The infamous Mount Laurel zoning scheme included an agerestrictive semor citizen classification. See Southern Burlington County NAACP v. Township of Mount Laurel, 67 N.J. 151, 168-69, 336 A.2d 713, 722, appeal dismissed and cert. denied, 423 U.S. 808 (1975).

308. See Shepard v. Woodland Township Comm. \& Planning Bd., 71 N.J. at 242 \& n.10, 364 A.2d at 1012 \& n.10; Elrod, supra note 204, at 741-42.

309. See Campbell v. Barraud, 58 A.D.2d 570, 573, 394 N.Y.S.2d 909, 913 (1977); Shepard v. Woodland Township Comm. \& Planning Bd., 71 N.J. at 248-49, 364 A.2d at 1016; Weymoulh Township, 71 N.J. at 294, 364 A.2d at 1040. 
While recognizing the mumicipality's desire to satisfy the social and psychological needs of the elderly . . . we required the mumicipality to articulate tangible, specific objectives promoted by the zoning measure - there the unusual physical and economic needs of the elderly. . . . We then carefully examine the factual bases of the municipality's conclusion that reserving mobile homes for the elderly in fact served those specific ends. 310

Although the "fact bases" test of Weymouth was developed to assess the limits of the zoning power under the relevant enabling legislation, it resembles tests formulated to determine the constitutionality of zoning. ${ }^{31}$ For example, in Belle Terre, the Court of Appeals for the Second Circuit stated that "the test for application of the Equal Protection Clause is whether the legislative classification is in fact substantially related to the object of the statute." 312 The fact bases test also recalls the various ends and means analyses einployed in a number of the traditional-family ordinance cases. ${ }^{313}$

Fact bases defenses-demonstrating the facts underlying a legislative classification and showing that the ordinance is factually related to its purported objective-have often succeeded in cases challenging agerestrictive ordinances authorizing retirement communities. A Connecticut court, in a comparatively early case invalidating such a measure, remarked that no credible evidence had been adduced to dexnonstrate the need for age-restricted housing for the elderly. ${ }^{314}$ In contrast, the Supreme Court of New Jersey in Weymouth and Shepard had available several studies, reports of governmental hearings, and other data ${ }^{315}$ that lent credence to the suggestion that the elderly have unique housing needs and thereby upheld the age classifications contained in the ordmances. The court could also conclude that the respective ordi-

310. State v. Miller, 83 N.J. 402, 414-15, 416 A.2d 821, 827 (1980) (emphasis added). One is left with the impression that it was some time after the Weymouth Township decision before the New Jersey court discovered that it had engaged in the analytical approach described. The court cites Developments in the Law-Zoning, supra note 11, at 1456-57, wherein the authors sought to rationalize the Weymouth Township court's behavior in regard to the real and substantial relationship to land use test. In Miller the court evidently adopted this explanation of Weymouth Township.

311. Indeed, the discussion in State $v$. Miller of the fact bases approach occurred in the context of a description of strict constitutional scrutiny. See 83 N.J. 402, 414-15, 416 A.2d 821, 827-28 (1980).

312. Boraas v. Village of Belle Terre, 476 F.2d 806, 814 (2d Cir. 1973) (emphasis in original), rev'd, 416 U.S. 1 (1974). The court of appeals was specifically rejecting the traditional two-tiered equal protection analysis. See supra text accompanying notes 130-36.

313. See supra text accompanying notes 147-57.

314. See Hinman v. Planning \& Zoning Comm'n, 26 Conn. Supp. 125, 129, 214 A.2d 131, 133 (1965).

315. Many of these resources are listed in Weymouth Township at 71 N.J. at 267-68, 364 A.2d at 1026 . 
nances actually responded to the goal of authorizing housing to satisfy the unique physical, psychological, and social needs of senior citizens. $^{316}$

The fact bases test formulated in Weymouth is not really new. The relation of a zoning ordinance to the public health, safety, inorals, or general welfare is essentially a question of fact in which courts have always expressed an interest. ${ }^{317}$ Alfred Bettınan explains,

Zoning cases raise in peculiarly urgent shape the problem of the extent to which the question of constitutionality is decided from the four corners of the measure or is one upon which evidence may be received and considered .... [F]act issues are necessarily involved in the issue of reasonableness .... . Our constitutional procedure would itself be unreasonable and arbitrary, if it were to permit a court to declare a zone plan unreasonable and arbitrary without hearing the facts upon which the plan was based and the principles which went into its making. ${ }^{318}$

The founders and early practitioners of zoning took particular care to amass factual inaterial: first, to help formulate a rational zoning plan and, second, to support the scheme in the event it came under attack in the courts. ${ }^{319}$ However, as one respected commentator has stated, the problem of zoning for appropriate amenity levels "is laced with . . . real but vague psychological elements." 320 Consequently, "[i]t is too much ever to expect watertight standards here."321 But fact bases are probably particularly important when a municipality uses zoning for direct social control. Such zoning by definition concerns the identity of land users and is readily susceptible to prejudicial uses. Moreover, most zoning for direct social control is of relatively recent origin, and "[t]he real obligation to base zoning provisions on fact comes when a new zoning technique is introduced." 322 Therefore, when confronted with direct social control zoning, a court should examine the factual basis for the legislative classification imposed and assess whether the measure in fact furthers its purported goals. In this

316. See Shepard v. Woodland Township Comm. \& Planning Bd., 71 N.J. at 240-42, 364 A.2d at 1010-12; Weymouth Township, 71 N.J. at 273-75, 364 A.2d at 1029-30.

317. See A. Bettman, The Fact Bases of Zoning, in City and Regional Planning Papers, supra note 99 , at 45.

318. Bettman, supra note 23, at 856-57; $c f$. Landels, Zoning: An Analysis of Its Purposes and Its Legal Sanctions, 17 A.B.A. J. 163, 167 (1931) (arguing that zoning in particular should not be judged by theoretical standards but by the concrete conditions which induced it); Williams, supra note 77, at 319 ("what is needed in planning law is a super-Brandeis-brief approach").

319. See, e.g., Citizens' Zone Plan Confrerence, Chicago, supra note 253, at 86; A. BETTMAN, supra note 99 , at 181-83.

320. Toll, Zoning for Amenities, 20 Law \& ConTEMP. Probs. 266, 269 (1955).

321. Id.

322. M. MCLEAN, supra note 82, at 7. 
fashion, the court can help ensure that the regulation is not used in an abusive fashion. ${ }^{323}$

3. Comprehensive Planning. A fact bases analysis could be performed through a requirement traditionally imposed in zoning enabling legislation. Section 3 of the Standard State Zoning Enabling Act states: "Such regulations shall be made in accordance with a counprehensive plan ...."324 The extent to which the comprehensive planning requirement can accommodate the fact bases test and aid in the avoidance of regulatory abuse is considered here. ${ }^{325}$

At the least, comprehensive planning articulates the goals of a municipahty's land use scheme, and communicates them to the courts when hitigation arises.326 For example, the New York Court of Appeals in upholding a retirement community ordmance was satisfied that the ordimance was based on the town's previously formulated goal of providing for the needs of the elderly because of the goal's explicit inclusion in the town's comprehensive plan. ${ }^{327}$ Thus, coinprehensive planning can aid a court in performing a fact bases analysis. With the purported goals of the zoning scheme clearly stated, the issue of whether the challenged ordmance in fact furthers those objectives in a reasonable fashion comes into sharp focus. ${ }^{328}$

Comprehensive planning may also help to ensure the legitimacy of land use goals. One court has stated that, without a comprehensive plan, "there can be no rational allocation of land use" and that such a plan "is the insurance that the public welfare is being served and that zoning does not become nothing more than just a Gallup poll."329 In

323. The burden of proof to show fact bases-or lack thereof-is probably as important as the test itself. See infra text accompanying notes 347-62.

324. Standard Act, supra note 54, \& 3.

325. In practice the import of the comprehensive plan requirement has not been clearly defined and often has not been accorded much weight by reviewing courts. See Tarlock, Consistency with Adopted Land Use Plans as a Standard of Judicial Review: The Case Against, 9 URB. L. ANN. 69, 82-83 (1975). Furthermore, the traditional comprehensive plan requirement contained in the Standard Act has been replaced with tailor-made language by a number of states. See R. ElLickSON \& A.D. TARLOCK, supra note 53, at 403-06. Insofar as these new statutory provisions require that comprehensive planning precede the enactment of a zoning ordinance (whether embodied in a separate document or not), the analysis in the text is unaffected by these developments.

326. See Eliott, Introduction to THE NEw ZoNING at xxii (N. Marcus \& M. Groves ed. 1970).

327. See Maldini v. Ambro, 36 N.Y.2d 481, 485 \& n.1, 330 N.E.2d 403, $405-06$ \& n.1, 369 N.Y.S.2d 385, 389 \& n.1, cert. denied, 423 U.S. 993 (1975).

328. Cf. Haar, In Accordance with a Comprehensive Plan, 68 HARv. L. REv. 1154, 1158, 1174 (1955) (when a municipality has a comprehensive plan that publicly sets out its objectives, an arbiter of land use disputes can assess the reasonableness of the implementing ordinances more effectively).

329. Udell v. Haas, 21 N.Y.2d 463, 469, 235 N.E.2d 897, 901, 288 N.Y.S.2d 888, 893-94 (1968). See R. NELSON, supra note 202, at 79 ("For many commumities, a formal comprehensive plan has 
Weymouth, the Supreme Court of New Jersey noted that illegal "spot zoning" was likely to occur when a municipality ignored the enabling legislation's comprehensive plan requirement. ${ }^{330}$ In Shepard, the same court found it reassuring that the age limitation imposed in the challenged ordinance was part of a comprehensive schene for land development. ${ }^{331}$ The inclusion of a traditional-family ordinance im a coinprehensive plan was of some importance to a lower New York court upholding the ordinance..$^{332}$

A planning requirement alone, lowever, cannot insure against arbitrariness. A zoning authority could disregard the facts or act on them capriciously and "[t]he municipal plan may be just as arbitrary and irresponsible as the municipal zoning ordinance if that plan reflects no inore than the municipality's arbitrary desires." 333 But the facts amassed in the planning process are useful in determining whetler a inunicipality has acted arbitrarily and, as noted above, because compreliensive planning encourages the clear articulation of goals, it lielps courts assess whether legislative action advances those objectives.

Fmally, if a court administers a fact bases test in accordance witl the statutory requirement that zoning regulations follow a comprehensive plan, or, as was the case in Weymouth, witl reference to the limits of the zoning power as delegated by state enabling legislation, the invalidation of an ordinance for not satisfying the standard would respect the value of local autonomy. The decision would not preclude either local governments or the state legislature from adopting a land use restriction exercising the challenged type of direct social control witl proper factual support. ${ }^{334}$ The state court decisions that have overturned traditional-family ordinances on substantive due process and otler constitutional grounds do not denıonstrate a similar respect for

provided important assurance to the judiciary that land-use regulations were being employed for a broad--planned'-public interest."); Heyunan, supra note 185, at 57 (planning lelps governments show that regulations are necessary to accoinplish desirable social objectives).

330. 71 N.J. at $261-62,364$ A.2d at 1023 .

331. 71 N.J. at $246-47,364$ A.2d at 1014-15.

332. People v. Kalayjian, 76 Misc. 2d 1097, 1099, 352 N.Y.S.2d 115, 118 (App. Term 1973).

333. R. BABCOCK, supra note 24, at 123. Cf. Hinman v. Plannimg \& Zoning Coinm'n, 26 Conn. Supp. 125, 129, 214 A.2d 131, 133 (C.P. 1965) (although vested with wide discrction in creating a coinprehensive plan a inunicipality "is not vested with unlimited authority, even in an endeavor to promote what it believes to be best to proinote lealth and general welfare").

334. Cf. Sandalow, The Limits of Municipal Power Under Home Rule: A Role for the Courts, 48 MiNN. L. REv. 643, 720 (1964) ("Indeed, avoidance of constitutional questions is a prinary purpose of permitting courts to invalidate an exercise of inunicipal power on the ground that it goes beyond the initiative conferred by a grant of houne rule.") (footnote ounitted); Bruff, Judicial Review in Local Government Law: A Reappraisal, 60 MrNN. L. REv. 669, 688 (1976) ("The courts can also avoid deciding serious constitutional issues by construing the local action to be unauthorized.") (footnote omitted). 
local autonomy. Had they applied a statutory basis of review, these courts could have examined the existing data allegedly supporting the requirement ${ }^{335}$ and, if unconvinced, simply found the fact bases lacking. Such review leaves municipalities free to adopt such regulations when they can inarshall sufficient factual support. It also allows a state legislature to provide a clear statutory signal that the impugned regulatory classification ineets with its approval, ${ }^{336}$ thus shielding the regulation from attack based on lack of statutory authorization. ${ }^{337}$

4. Comprehensive Plan for Balanced Housing Stock and Alternative Sites. Among other things, a coinprehensive plan can specifically provide for a balanced housing stock within the municipality. In $\mathrm{Wey}$ mouth, the Public Advocate argued that because the age-restrictive zoning at issue posed an exclusionary threat, it should be sustained only within the context of a comprehensive housing plan. ${ }^{338}$ Although the court did not remand the case for further hearings about the inunicipahity's housing stock, it did express the view that "the Public Advocate's recommendation that zoning for planned housing developinents for the elderly be permitted only as part of a comprehensive inunicipal plan for a balanced housing stock presents a reasonable mechanisin for averting the potentially exclusionary effects of such zoning." 339

This sort of comprehensive housing plan has often been used in efforts to allocate low- and moderate-income housing throughout a mumicipahty or region. ${ }^{340}$ Such plans are based on the principle that the general welfare "contemplates housing for all categories of people in both the community and the surrounding region." 341

Related to the notion of a balanced housing stock is whether the availability of alternative housing should affect the validity of an agerestrictive ordimance or other type of direct social control zoning. If

335. See, e.g., Lupu, supra note 192, at $1053 \& \mathrm{nn} .338 \& 339$ (citing sources).

336. See State v. Baker, 81 N.J. 99, 118-21, 405 A.2d 368, $377-78$ (1979) (Mountain, J., dissenting) (discussing City of Des Plaines v. Trottner, 34 Ill. 2d 432, 216 N.E.2d 116 (1966)). In criticizing this position, Professor Williams has suggested that turning the inatter over to the state legislature only places it in the hands of the "dominant suburban forces." See 3 N. Williams, supra note 9, \$66.13f at 34-35 (Supp. 1981).

337. Cf. Bruff, supra note 334, at 688 ("a holding that statutory authorization is absent has the effect of inviting legislative consideration of the appropriateness of a particular local program").

338. 71 N.J. at 288,364 A.2d at 1037.

339. Id. at 293,364 A.2d at 1040 .

340. See generally H. Frankin, D. FalK \& A. Levin, IN-Zoning 145-75 (1974); M. DANIELSON, supra note 12, at 242-78; R. BABCOCK \& F. BOSSELMAN, supra note 11, at 108-31.

341. Shepard v. Woodland Township Comm. \& Planning Bd., 71 N.J. at 238, 364 A.2d at 1010 (emphasis in original); Weymouth Township, 71 N.J. at 293, 364 A.2d at 1040 (developing municipalities inust provide, by their land use regulations, "the opportunity for an appropriate variety and cloice of housing for all categories of persons who may desire to live there."). 
excluded individuals can obtain similar housing nearby, they would seein to have no more cause to complain about a given zoning restriction than if it represented part of a coinprehensive scheine specifically addressed to the problem of achieving a fair balance in housing allocation. Nevertheless, the concept of alternative housing sites has received a mixed reception in cases considering the validity of traditional-family ordinances.

In contrast, courts appraising the validity of age-restrictive land use controls other than zoning have upheld private restrictions of limited geographic scope when no showing was inade of a shortage of housing for families with children. ${ }^{342}$ And the Supreme Court of New Jersey in Weymouth thought it "obvious that the seriousness of any exclusionary threat will depend upon the circumstances of each case, including in particular the relationship which the population, area, and available vacant land within the municipality bears to that witlim the areas occupied by the senior citizens communities." 343

The number of alternative housing opportunities in an urban area is vitally relevant to the issue of the exclusionary impact of an ordinance. The relevance of alternative housing to the issue of legislative classification, however, presents a inore controversial ${ }^{344}$ and delicate problem. For instance, to argue that the availability to a racial minority of ample housing should sustain the legislative classification contained in a segregation ordinance would be to return to the doctrine of Plessy v. Ferguson. ${ }^{345}$ But if the legislative classification involved a less invidious distinction, such as that between relatedness and unrelatedness in a traditional-family ordinance, or that between one age and another in a retireinent community measure, neither distinction being clearly suspect under the equal protection clause, the availability of alternate housing should carry inore weight. ${ }^{346}$

342. See Riley v. Stoves, 22 Ariz. App. 223, 228, 526 P.2d 747, 752 (1974); Franklin v. White Egret Condomininm, Inc., 358 So. 2d 1084, 1092 (Fla. Dist. Ct. App. 1978) (Letts, J., dissenting), affd, 379 So. 2d 346 (Fla. 1979).

343. 71 N.J. at 292,364 A.2d at 1039.

344. Compare Doyle, supra note 184, at 95 n.125 ("Expulsion from one's home, even if alternative housing is available, is a sanction sufficiently serious to warrant . . . constitutional protection.") with Travalio, supra note 123, at 315 \& n.138 (If the result of age-restrictive ordinances is not unreasonable, such ordinances should be upheld as long as the age restrictions apply to only a small portion of the mnnicipality.).

345. 163 U.S. 537 (1896). Courts have sometimes embraced the notion of regionatism, which is closely related to the concept of alternative honsing sites, to uphold exclusionary land use controls. See Burchell, Listokin \& James, supra note 186, at 36-37; see also Feiler, Metropolitanization and Land-Use Parochialism-Toward a Judicial Attitude, 69 Mich. L. REv. 655, 667-73 (1971).

346. Cf. L. TRIBE, supra note 171, at 989:

If . . . it can be demonstrated that a commnnity's efforts to preserve its character [through a traditional family ordimance] do not operate to freeze out alternatives indefi- 
When an ordinance exercising direct social control coines before a court, the judge inevitably faces competing values: he must balance mumcipal self-determinisın against individual freedorn in domestic associations. The court may find the factual basis for the legislative classification a little weak, or it may find some misalignment between ends and ineans. If so, the validity of the ordinance may depend on whether suitable alternative lousing is available for the excluded individual. If the excluded individual can obtain suitable alternative housing, the ordinance's unscientific design or less than exacting operation might be tolerable. But if im addition to its general slioddiness the ordmance has the effect of closing the doors of an urban area to a certain group, or of substantially reducing the group's housing choices, the measure should be struck down. Courts should consider this sort of balancing process in seeking to adequately recognize the competing values at stake when appraising zoning for direct social control.

5. Presumptions and Burdens of Proof. As noted earlier, zoning regulations are traditionally presumed valid. ${ }^{347}$ Courts upholding retirement community ordinances have generally relied on, or at least used the rhetoric of, this presuinption. ${ }^{348}$ Furtlermore, the party challenging a zoning ordinance traditionally has the burden of establishing its invalidity. ${ }^{349}$ In recent years, lowever, im attempting to prevent the unjust exercise of inunicipal zoning power, courts lave sometimes

nitely or to exclude them from an area wider than a few square miles, such efforts should be regarded as entitled to at least some constitutional protection from the imposed uniformity of state or federal law.

Michelman, supra note 144, at 196-97 (discussion of coucept embodied in the question: "Why should the plaintiffs [im Belle Terre] prevail-at least as long as they can, without great loss or inconvemience, live nondisruptively somewhere else?").

347. See 1 R. ANDERSON, AMERICAN LAW OF ZoNING \$3.14 (2d ed. 1976); Comment, supra note 128.

There are many policy reasons behind the strong presumption of constitutionality traditionally applied to zoning ordmances. A zoning ordinance is a legislative decision, to be accorded the saine defereuce as state or federal legislation. The local nuunicipal governing body ordinarily has more knowledge of local affairs and expertise in fashioning ordinances to suit local conditions. Finally, the presuniption acts to protect the nuunicipality from liarassing attacks on its zoning plans. It seems hardly justified to discard the traditional presumption of constitutionality simply because it is easier for a plamtiff to challenge the ordinance or because it might be administratively nore convenient.

Id. at 676 (footnotes omitted).

348. See Weymouth Township, 71 N.J. at 264, 364 A.2d at 1024; Maldini v. Ambro, 36 N.Y.2d 481, 484, 330 N.E.2d 403, 405, 369 N.Y.S.2d 385, 389, cert. denied, 423 U.S. 993 (1975).

349. See 1 R. ANDERson, supra note 347, § 3.16; see, e.g., Campbell v. Barraud, 58 A.D.2d 570, 571, 394 N.Y.S.2d 909, 912 (1977) (age-restrictive ordinance). 
abandoned the presumption of validity and shifted the burden of proof. ${ }^{350}$

Courts have made the most notable modifications in the traditional rules about presumptions and burdens of proof in the context of cases dealing with exclusionary land use schemes. ${ }^{351}$ One court specifically observed that traditional presumptions should be eradicatcd and the customary burden of proof shifted when assessing an age-restrictive ordinance shown to be exclusionary. ${ }^{352}$ But the presumption of validity has also played a role in the judicial assessment of the legislative classifications contaimed in zoning restrictions. In Euclid, the Supreme Court suggested the standard of proof required to overcome the traditional presumption: "If the validity of the legislative classification for zoning purposes be fairly debatable, the legislative judgment must be allowed to control . . . ."353

There are at least two reasons why a court might impose the burden of demonstrating the validity of classifications contained in a zoning ordimance on a mumicipality. One reason is the potential for abuse of such ordmances. ${ }^{354}$ Public restrictions dictating who may live where are a radical alteration of traditional property rules; the restricting body should show some solid basis for such novel intervention. Furthermore, "[i]t would appear that a requirement of articulation will expose local parochialism when it is contrary to the public interest and force local legislators to consider carefully their reasons for enacting an ordimance when larger public interests may be at stake."35s A second reason is that the inumicipahty is usually the party best able to indicate the purpose and circumstances promptimg a zoning law. ${ }^{356}$ Presumably, the local governing body is best equipped to reveal the planning studies or other factual materials, if any, on which it based its legislative line-drawing.

350. See, e.g., Bosselman, supra note 128, at 260-62; Note, supra note 128, at 147; Note, LandUse Controls: Is there a Place for Everything?, 6 Sw. U.L. REv. 607, 629-33 (1974); Comment, supra note 128.

351. See generally 1 R. ANDERSON, supra note 347, § 3.19.

352. See Weymouth Township, 71 N.J. at 295 n.20, 364 A.2d at 1041 n.20.

353. Village of Euclid v. Ambler Realty Co., 272 U.S. 365, 388 (1926).

354. For example, courts have been compelled to assume a particularly active role in attempting to ensure that group homes are not unfairly excluded from preferred residential districts by traditional family ordinances. See, e.g., State ex rel. Ellis v. Liddle, 520 S.W.2d 644 (Mo. Ct. App. 1975); Abbott House v. Village of Tarrytown, 34 A.D.2d 821, 312 N.Y.S.2d 841 (1970) (mem.).

355. Feiler, supra note 345 , at 702.

356. See generally, James, Burdens of Proof, 47 VA. L. Rev. 51, 60 (1961). The principle that the party with the readier access to a given fact in question may justifiably be allocated the burden is not the only consideration that infuences the allocation of the burden and "it is by no means always controlling." Id.; cf. Note, Legitimate Use Exclusions Through Zoning: Applying a Balancing Test, 57 CORNELL L. REv. 461, 475 (1972) (by removing the burden of proof from the challenger it "is placed upon the municipality, the party with the particular expertise"). 
A court deciding to shift the burden of proof onto a municipality must also decide the extent of this shift. It could simply impose on the mumicipality the burden of production; to prevent the invalidation of its zoning regulation the municipahty would have to adduce some evidence of the purpose of the legislative classification and the factual data upon which it was grounded, but the ultimate burden of proving that the restriction is unreasonable would remain with the challenging party. ${ }^{357}$ On the other hand, the risk of nonpersuasion might also be placed on the municipality, requiring that it fully demonstrate the vahidy of its zoning ordinance. ${ }^{358}$

In assessing the validity of direct social control zoning such as agerestrictive and traditional-family ordinances, some courts understandably desire to shift at least the burden of production to the municipality. ${ }^{359}$ Because the concerns underlying these ordinances are intangible, and the impact that they can have on residential lifestyles is far-ranging, courts should seek the best source of evidence of the goals and factual bases of a given ordinance. But shifting the burden of persuasion as well would devalue local autonomy ${ }^{360}$ and would represent a nuch more radical departure froin the traditional rule.

To whatever extent any burden-shifting occurs, it could be effected by at least two different means. A mumicipality could be required to satisfy a fact bases test im the context of administering the requirement, found in most zoning enabling acts, that regulations "be made in accordance with a coinprehensive plan." 361 Requiring the presentation of such a plan could effect a shift im the burden. On the other liand, some courts appraising traditional-family ordinances liave removed the presumption of validity, or liave shifted the burden, in tlie course of active substantive review pursuant to the due process or equal protection ${ }^{362}$ clauses of the fourteentli amendment or comparable provisions of state

357. See generally Comment, Burden of Proof in Land Use Regulation: A Unified Approach and Application to Florida, 8 FLA. ST. U.L. REV. 499, 500-01 (1980).

358. See generally, 1 R. ANDERSON, supra note $347, \S 3.18$, at 117 . The two distinct ineanings of "burden of proof" are succinctly discussed in Cole-Collister Fire Protection Dist. v. City of Boise, 93 Idaho 558, 568-69, 468 P.2d 290, 300-01 (1970).

359. Cf. L. TR1BE, supra note 171, at 989 ("But the embedding of a choice within a close human relationship or network of relatiouships should always be regarded as significantly increasing the burden of justification for those who would make the choice illegal or visit it with soine deprivation.") (emphasis deleted).

360. Cf. Comment, supra note 128 , at 679 ("The presumption of constitutionahty surrounding zoning ordimances rests on the assumption that zoning is best left in local hands.") (footnote omitted). Shifting the burden to this extent would also undercut any notion of judicial restraint.

361. Standard Act, supra note 54, $\$ 3$.

362. Cf. Note, supra note 350 , at 623 ("It has been suggested that the equal protection clause could be used to strip zoning of its presumption of validity.") (footnote omitted). 
constitutions. Through either means the burden-shifting could occur without any radical departure from the usual methods of judicial appraisal of zoning ordinances.

\section{ZoNing For Direct Social Control: Indigents, STUdENTS, Racial Minorities, AND BEyond}

\section{A. Inclusionary Zoning.}

Professor Norman Williams has defined exclusionary land use controls as "those which interfere seriously with the availability of housing for low- and moderate-income people in areas where such housmg is much needed." 363 The converse of this definition describes inclusionary land use controls: regulations that promote the availability of housing for low- and moderate-mcome people where there is a need for such housing. ${ }^{364}$ At one time the law imposed no affirmative duty to exercise zoning power in an inclusionary fashion. ${ }^{365}$ In recent years, however, some state courts have imposed a legal duty on municipahties to administer land use in such a way as to encourage housing for low- and moderate-mcoine groups. ${ }^{366}$ Additionally, certain local ${ }^{367}$ and state governments ${ }^{368}$ have adopted inclusionary land use programs.

Inclusionary land use techniques include variances, special permits, conditional zoning, incentive zoning, and planned unit develop-

363. 2 N. Williams, supra note $9, \$ 64.10$, at 666 . Some commentators use the term "exclusionary" to mean "restrictive" or "particularly restrictive." For example, 1 P. RoHAN, ZoNING AND LAND USE CONTROLS (1978), includes discussion of traditional-family ordinances and agerestrictive zoning in a chapter on exclusionary land use controls. See id., $\$ \$ 3.04 \& 3.05$ [1]. The use of "exclusionary" in this broad sense is problematic; the term connotes abuse, and one should not state categorically that traditional-family ordinances and age-restrictive zoning are abusive. Hence, it is preferable to use "exclusionary" in the narrower sense of Professor Williams' definition. This article employs this definition.

364. Cf. Comment, Board of Supervisors v. DeGroff Enterprises, Inc.: A Case of Inclusionary Zoning, 60 IowA L. REv. 413, 416 (1974) ("Unlike exclusionary zoning, mclusionary zoning refers to ordinances which open the suburban market to lower income people").

365. See H. FranKiIN, D. FaLK \& A. Levin, supra note 340, at 1.

366. See H. FrankLIN, D. FALK \& A. Levin, supra note 340, at 209; Pazar, Constitutional Barriers to the Enactment of Moderately Priced Dwelling Unit Ordinances in New Jersey, 10 RuT.CAM. L. Rev. 253 at 253, 257-59 (1979); Comment, supra note 364, at 420-21.

367. See Kleven, Inclusionary Ordinances-Policy and Legal Issues in Reguiring Private Developers to Build Low Cost Housing, 21 U.C.L.A. L. Rev. 1432, 1436 (1974). Professor Kleven notes that the "reasons for this change in attitude are not yet entirely clear." He suggests as possibilities the desire of suburban mumicipalities to 1) avoid exclusionary zoning litigation; 2) satisfy the housing needs of retiring residents or adult children of present residents; or 3) attract with appropriate housing opportunities lower-paid workers who are needed in the relevant arca. See also Rose, The Mandatory Percentage of Moderately Priced Dwelling Ordinance (MPMPD) is the Latest Technique of Inclusionary Zoning, 3 REAL EsT. L.J. 176 (1974).

368. See Kleven, supra note 367, at 1436 n.7; Pazar, supra note 366, at 255 n.11. 
ments. When used in the appropriate manner, all of these can encourage the construction of low- and moderate-income housing. ${ }^{369}$ Zoning for direct social control can also accomplish this end. This technique for inclusionary results has variously been called the "mandatory percentage of moderately priced dwelling ordmance" (MPMPD), 370 "moderately priced dwelling unit ordinance" (MPDU), 371 and simply "inclusionary zoning" or the "inclusionary ordimance." "372 These inclusionary ordinances seek to increase the supply of low- and moderate-income housing by requiring developers to include a stipulated amount of such housing in their residential construction projects or by encouraging developers to voluntarily incorporate such housing in their projects. ${ }^{373}$ Mandatory ineasures generally attempt to compensate the developer for producing lower cost units by granting him relaxed zoning restrictions, government subsidies, or density bonuses. Voluntary ordinances usually contain incentive zoning provisions. ${ }^{374}$ The most interesting feature of these ordinances is that they generally limit the sale or rental of the designated units to low- or moderate-income families. ${ }^{375}$ Thus a new application of zoning for direct social control arises: land users can live im specified dwelling units on the basis of income level, a normally stable personal characteristic explicitly identified in these ordimances. Inclusionary ordinances "overtly intend . . . to benefit a class of persons on the basis of their economic station in life rather than on the basis of the distmguishing features of the land they own or occupy."376

The inclusionary ordinance adopted by the Board of Supervisors of Fairfax County, Virginia, is similar to many other regulatory efforts in this area ${ }^{377}$ and was the first such ordinance to be subjected to litigation. ${ }^{378}$ The measure was adopted as an amendment to the municipality's zoning ordinance on June 30, 1971, and was the first measure of its

369. See H. FRANKLIN, D. FALK \& A. LEVIN, supra note 340, at 113-43; Comment, supra note 364, at 416-17; Note, Municipalities and the Increasing Need for Low and Moderate Income Housing, 28 WASH. \& LEE L. REV. 408 (1971).

370. See Rose, supra note 367.

371. See Pazar, supra note 366.

372. See Kleven, supra note 367; Comment, supra note 364.

373. See Kleven, supra note 367, at 1437; Fox \& Davis, Density Bonus Zoning to Provide Low and Moderate Cost Housing, 3 Hastings Const. L.Q. 1015, 1028 (1976).

374. See Fox \& Davis, supra note 373, at 1028.

375. See, e.g., H. FRANKLIN, D. FALK \& A. Levin, supra note 340, at 131.

376. Id. at 106.

377. Other municipalities' ordinances do vary in their details. See generally id. at 131-41; Fox \& Davis, supra note 373, at 1036-65; Kleven, supra note 367, at 1439-48; ABA ADVISORY CommisSION ON HOUSING AND URBAN GROWTH, supra note 109, at 584-85; see also Pazar, supra note 366 , at $253 \mathrm{n} .2$ (quoting ordinance of Cherry Hill, New Jersey).

378. See Board of Supervisors v. DeGroff Enters., 214 Va. 235, 198 S.E.2d 600 (1973). 
kind to be enacted in the United States. ${ }^{379}$ It required a developer of fifty or more dwelling units in certain zones to commit himself, before re-zoning or site plan approval, to build at least fifteen percent of the units as low- and inoderate-inconie dwellings. ${ }^{380}$ The amendment further provided that, on completion of the project, the developer could sell the designated units only to persons of low and noderate incoine at prices not exceeding governmental guidelines. ${ }^{381}$ The schenie relied on government housmg subsidies ${ }^{382}$ and, in all but exceptional cases, afforded developers a density bonus to aid in reducing the fiscal burden of building the low-cost units. ${ }^{383}$

The Virginia Supreme Court invahidated Fairfax County's inclusionary ordmance in Board of Supervisors v. DeGroff Enterprises. ${ }^{384}$ The court found that the intention of the state's zoning enabling act "was to permit localities to enact only traditional zoning ordinances directed to physical characteristics and having the purpose neither to include nor exclude any particular socio-economic group." 385 It concluded that the Fairfax amendment iniproperly involved "socio-economic zoning" and further exceeded the bounds of the enabling legislation by seeking to "control the compensation for the use of land." 386 The court also lield that, in requiring developers to rent or sell the designated units at "prices not fixed by a free market," the inclusionary scheme amounted to a taking without conipensation in violation of the Virginia constitution. ${ }^{387}$

379. See Kleven, supra note 367, at 1439. Like other zoning for direct social control, inclusionary zoning is of recent origin.

380. The relevant definitions of low- and moderate-income housing were those pronulgated by the Fairfax County Housing and Redevelopinent Authority and the United States Departinent of Housing and Urban Developinent. See Board of Supervisors v. DeGroff Enters., 214 Va. 235, 235-36, 198 S.E.2d 600, 601 (1973). For more extensive descriptions of the Fairfax County amendment, see Kleven, supra note 367, at 1439-42; Comment, supra note 364, at 417-18.

381. See Board of Supervisors v. DeGroff Enters., 214 Va. 235, 236, 198 S.E.2d 600, 6Cl (1973).

382. See Kleven, supra note 367 , at 1439 \& n.18.

383. See id. at 1440.

384. 214 Va. 235, 198 S.E.2d 600 (1973). A companion case to DeGroff was Board of Supervisors v. Lukinson, 214 Va. 239, 198 S.E.2d 603 (1973). In a per curiam opinion the court followed the result in DeGroff for the saine reasons expressed therein. A case which considered inclusionary conditions attached to a special permit for the construction of an apartinent developinent was Middlesex \& B. St. Ry. v. Board of Aldermen, 371 Mass. 849, 359 N.E.2d 1279 (1977). The Massachusetts court invalidated the inclusionary condition on the basis that the board had exceeded its statutory authority. Id. at 1284.

385. $214 \mathrm{Va}$ at 238,198 S.E. $2 \mathrm{~d}$ at 602 .

386. Id.

387. Id. 
The DeGroff decision has been criticized ${ }^{388}$ and with good reason. As this article has pointed out, all zoning has inherent socioeconomic imphications. ${ }^{389}$ The Standard Act and legislation based upon it delegates power very broadly and may confer upon municipalities the full extent of the state's police power with respect to the regulation of land use. ${ }^{390}$ Commentators have noted that the socioeconomic features of inclusionary zoning resemble those of age-restrictive ordinances which affirmatively provide housing opportunities for the elderly, ${ }^{391}$ and courts have usually been sympathetic to age-restrictive zoning. ${ }^{392}$ But the extensive use of enabling legislation like Virginia's, a variation of the Standard Act, could give DeGroff widespread influence in future judicial appraisals of inclusionary schemes. ${ }^{393}$ The consensus of the commentators is that inclusionary ordmances will not face an enabling act challenge in states such as New Jersey and Pennsylvania that have a broad conception of zoning as capable of promoting the "general welfare." ${ }^{394}$ DeGroff may reflect an archaic legal perspective: the Virgimia courts have a tradition of construing narrowly delegations of authority from the state to local governments, thus being one of the few jurisdictions still adhering to the so-called Dillon's rule. ${ }^{395}$ One commentator

388. See generally H. FrankiIn, D. FALK \& A. Levin, supra note 340, at 138-39; ABA AdviSORY COMMISSION ON HOUSING AND URBAN GROwTH, supra note 109, at 588-92; National Committee Against Discrimination in Housing and the Urban Land Institute, Fair Housing and Exclusionary Land Use 50 (ULI Research Report 23, 1974); Comment, supra note 364, at 413; Note, Socio-Economic Zoning: One Court's Response, 35 U. PITT. L. REv. 837 (1974).

389. See, eg. H. Franklin, D. FALK \& A. Levin supra note 340, at 138; ABA Advisory COMMISSION ON HousING AND URBAN GRowTH, supra note 109, at 588; Rose, supra note 110, at 323; Note, supra note 388, at 841.

390. See H. FrANKLIN, D. FALK \& A. Levin supra note 340, at 138; Note, supra note 369, at $410 \mathrm{mi} .17 \& 18$.

391. See ABA Advisory COMmission ON Housing AND URBAN GRowtH, supra note 109, at 590-91; Pazar, supra note 366, at 261-63.

392. See supra notes 197-306 and accompanying text.

393. See Comment, supra note 364 , at 418.

394. See Rose, supra note 367, at 179; Pazar, supra note 366, at 260-61; Comment, supra note 364 , at 423 . Of course, legislatures could amend the enabling legislation to specifically authorize mclusionary objectives. See Rose, supra note 367, at 179; Note, supra note 388, at 842 . Municipalities could also avoid DeGroff by basing inclusionary programs on home rule powers, a course some local governments have followed. See H. Franklin, D. FALK \& A. Levin, supra note 340, at 138-39 (" $[\mathrm{B}]$ ecause of the questions raised by resting mandatory inclusionary ordimances on the state zoning enabling laws, both the Montgomery County [Maryland] and Los Angeles ordinances are authorized instead by the pohice powers granted to those communities under their home rule charters."); see also Pazar, supra note 366, at 262 n.42 (it might be argued that inclusionary ordinances are authorized in New Jersey by the state's home rule statute, N.J. STAT. ANN. \$ 40:48-2 (West 1967)).

395. See ABA ADVISORY COMMISSION ON HousING AND URBAN GROwTH, supra note 109, at 588 n.447. Dillon's Rule einbodies the following proposition:

It is a general and undisputed proposition of law that a municipal corporation possesses and can exercise the following powers, and no others: First, those granted in express 
has simply dismissed the decision as an "aberration."396

Despite its idiosyncratic reading of the state enabling legislation, ${ }^{397}$ the DeGroff court conceded that "providing low and moderate income housing serves a legitimate public purpose." 398 Other courts have reached similar conclusions, ${ }^{399}$ and soine have even imposed an affirmative duty to promulgate inclusionary controls. In the landmark Mount Laurel case, the Supreine Court of New Jersey ruled that a developing inunicipality must "plan and provide, by its land use regulations, the reasonable opportunity for an appropriate variety and clioice of lousing, including, of course, low and inoderate cost lousing, in order to nieet the needs, desires and resources of all categories of people who may desire to live within its boundaries." 400

Inclusionary zoning deinonstrates low governmental regulation increasingly proinotes the interests of narrow groups in society. ${ }^{401}$

words; second, those necessarily or fairly implied in or incident to the powers expressly granted; third, those essential to the accomplishment of the declared objects and purposes of the corporation, - not simply convenient, but indispensable.

1 Dillon, Commentaries on the Law of Municipal Corporations $448-49$ (5th ed. 1911) (emphasis in original).

396. See Note, Required Low-Income Housing in Residential Developments: Constitutional Challenges to a Community Imposed Quota, 16 ARIz. L. REv. 439, 441 n.12 (1974).

397. The constitutional implications of inclusionary zoning with respect to the taking issue, also raised by the DeGroff decision, have been carefully examined in other commentaries. See e.g., Fox \& Davis, supra note 373, at 1031-32; Pazar, supra note 366, at 273-75; Note, supra note 388, at 844-49; Comment, supra note 364, at 424-27. But the Virginia court did not address the constitutional aspects of classifying the land users for inclusionary zoning. Income classification for such zoning would easily satisfy substantive due process: providing housing for low- and moderate imcome persons is a legitimate governmental goal, see Kleven, supra note 367, at 1509 10; Comment, supra note 364, at 443-44, and inclusionary measures seem the most direct way to accomplish this end. Moreover, imclusionary zoning impinges on no "fundamental" interest that might trigger more aggressive substantive due process review under the Supreme Court's plurality opimion in Moore v. City of East Cleveland, 431 U.S. 494 (1977). Inclusionary zoning also warrants deferential equal protection appraisal. The Supreme Court has not held classifications based on wealth alone to be suspect, see San Antonio Indep. School Dist. v. Rodriguez, 411 U.S. 1 (1973), nor has the Court made access to housing a fundamental right, see Lindsey v. Normet, 405 U.S. 56, $73-74$ (1972).

398. Board of Supervisors v. DeGroff Enters., 214 Va. at 237, 198 S.E.2d at 601.

399. See, e.g., Board of Appeals v. Housing Appeals Comm. in the Dep't of Community Affairs, 363 Mass. 339, 384-85, 294 N.E.2d 393, 424 (1973); Kleven, supra note 367, at 1505 n.227 ("There can now be no doubt about the validity of the public purpose of legislation designed to produce housing for low and moderate income people.") (citing cases); id. at 1508-10 (citing and discussing cases); Comment, supra note 364, at 420-21 (citing and discussing cases). Some state legislatures have adopted anti-exclusionary legislation. See Pazar, supra note 366, at 255 n.11 (citing and discussing statutes).

400. Southern Burlington County NAACP v. Township of Mount Laurel, 67 N.J. 151, 179, 336 A.2d 713, 728, appeal dismissed and cert. denied, 423 U.S. 808 (1975). The court subsequently elaborated on this affirmative duty in Oakwood at Madison, Inc. v. Township of Madison, 72 N.J. 481, 512, 371 A.2d 1192, 1207 (1977).

401. Of course, society in general benefits when all its members are housed adequately because problems sueh as the spread of disease and a less than fully productive workforce are 
Whether this tendency is because of the rise in political interest groups' effectiveness, the increased complexity or balkanization of society, or simply because governments are exploring more regulatory areas than they did in the past is uncertain. But as a type of zoning for direct social control, the inclusionary ordmance illustrates the increasingly discerning intervention imto the marketplace undertaken through pubhic control of land use. ${ }^{402}$

\section{B. Zoning with Respect to Students.}

Housmg for college and university students has long received special treatment in comprehensive zoning schemes. ${ }^{403}$ Some of the earliest zoning cases involved ordmances excluding fraterunty and sorority houses froin residential districts. ${ }^{404}$ Generally speaking, courts have supported such zoning restrictions. 405 One case noted that "[s]tudent housimg has been for 800 years a distinguishable subject matter for social and governmental restrictions."406

Soine municipahities have, however, gone beyond the simple regulation of fraternity and sorority houses as land uses and adopted zoning ordinances explicitly identifying students as a class and imposing unique restrictions on their use of land. For example, one zoning measure provided in part that "[n]o more than four (4) students will be rooined in any one house." 407 Judging from how few reported cases consider this type of ordinance, ${ }^{408}$ these zoning provisions are either rare or have failed to generate much litigation. 409

Arguments of density control often support the adoption of restric-

thereby alleviated. Nevertheless, like age-restrictive zoning, inclusionary ordinances appear to confer substantial benefits on one sector of the population.

402. Review of inclusionary zoning, like review of other forms of zoning for direct social control, could benefit from fact bases analysis, presentation of a comprehensive plan, or of a plan detailing the particular balance in housing sought by the inclusionary ineasure. See ABA ADVISORY COMMISSION ON HOUSING AND URBAN GRowTH, supra note 109, at 587-88, $590 \mathrm{n} .452$; Comment, supra note 364 , at 428 . The latter are probably always available because inclusionary measures are usually conceived with regard to the housing situation in the rest of the community. Thus, placing the burden of production on the inunicipality would also seem appropriate.

403. See generally 2 N. WilliaMs, supra note 9, \$\$ 58.04-58.09 (1974).

404. See, eg., Pettis v. Alpha Alpha Chapter of Phi Beta Pi, 115 Neb. 525, 213 N.W. 835 (1927); City of Syracuse v. Snow, 123 Misc. 568, 205 N.Y.S. 785 (Sup. Ct. 1924).

405. See 2 N. WilliaMs, supra note $9, \S 58.05$.

406. Boraas v. Village of Belle Terre, 367 F. Supp. 136, 148 (E.D.N.Y. 1972), affd, 416 U.S. 1 (1974), rev'g 476 F.2d 806 (2d Cir. 1973).

407. Township of Ewing v. King, 131 N.J. Super. 29, 30, 328 A.2d 242, 242 (App. Div. 1974), rev'd on other grounds, 69 N.J. 67, 350 A.2d 482 (1976); cf. Provo City v. Hansen, 585 P.2d 461 (Utah 1978) (per curiam) (considering a similar ordinance).

408. See cases cited supra note 407.

409. Perhaps there is little hitigation because students often have limited access to local legal services. 
tions on student housmg. ${ }^{410}$ Other arguments might include noise control, traffic control, and preservation of community character. ${ }^{411} \mathrm{~A}$ generally unexplored question, however, is whether local governments could zone affirmatively for direct social control with respect to students. Would a planned community restricted to occupation by college and umversity students represent a legitimate use of the local zoning power? "[S]tudent housmg, specifically as such and oriented to the idea that students wisl to live and learn together, is a matter that has been regarded as impressed with a public interest," 412 and local governments have on occasion exercised powers of emment domain and pledged public credit to permit the construction of student housing. ${ }^{113}$ Thus, the public interest imight well support the affirmative use of zoning power for students. This group of land users have social, educational and possibly even psychological reasons for desiring to live among their peers. ${ }^{414}$

Moreover, students have some special needs that the physical plan of a housing development devoted to their exclusive occupation could recognize. For one, the residents of a planned community for university students would have an interest in being located near the mstitution they were attending; for another, the physical design of the facility might take into account the collective recreational and social interests of this group. Conceptually, a planned community for university students would differ little from the retirement communities considered earher in this article. ${ }^{415}$

Negative restrictions on student populations are also similar to age-restrictive ordmances in that some courts have treated negative student zoning with similar deference. For example, the court in Township

410. See Township of Ewing v. King, 131 N.J. Super. 29, 31-32, 328 A.2d 242, 242 (App. Div. 1974), rev'd on other grounds, 69 N.J. 67, 350 A.2d 482 (1976).

411. See supra notes 54-103 and accompanying text.

412. Boraas v. Village of Belle Terre, 367 F. Supp. 136, 148 (E.D.N.Y. 1972), affd, 416 U.S. 1 (1974), rev'g 476 F.2d 806 (2d Cir. 1973).

413. Id.

414. See id. Cf. R. NeLSON, supra note 202, at $42-43$ ("In fact, there are strong trends toward greater social segregation of living patterns generally .... Solne exainples are 'singles' apartment complexes, retirement communities, university towns for youth, and rural coinununes.") (emphasis added).

415. A planned community for university students could very well be a financially advantageous land use from a municipality's viewpoint. Because university students rarely have schoolage children, a municipahty could permit such a developinent and collect the tax revenues it generated without fear of overburdening the local school systein. From the standpoint of the local tax base, it would be much better to house students in a private community authorized by an appropriate zoning restriction than to have then living in a dormitory owned by a state university, because state university property is immune from local taxation. See 16 E. MCQuiLlin, THE LAW OF MuNicipal Corporations $\$ 44.56$ (3d ed. 1979). 
of Ewing v. King ${ }^{416}$ dismissed constitutional claims against an ordinance limitimg the number of students allowed in any house by stating "[z]oning ordinances are to be hberally construed in favor of the municipality," and then relying on the traditional presumption of vahidity accorded zoning ${ }^{417}$ to uphold the measure.

Such deference may not always be appropriate. Certainly regulatory classifications with respect to students have not been considered "suspect" for equal protection purposes. And the reasoning of the Supreme Court im Belle Terre suggests that the Ewing ordinance would not trigger strict scrutimy at the federal level by violating a fundainental right. Guarantees of fundamental rights in state constitutions have, however, been interpreted more broadly than their counterparts in the United States Constitution. Recent cases in California ${ }^{418}$ and New Jersey ${ }^{419}$ have held that the freedom to choose one's domestic associates is strongly protected by privacy rights under the constitutions of those states. Therefore, in zoning for direct social control with respect to students, a municipality miglit liave to deınonstrate that the zoning advanced a compelling government interest. Moreover, a court might require a municipality to show why less restrictive means such as the active enforcenient of traffic, anti-noise, and other general police power ordmances could not satisfy the goals sought to be achieved by limiting the number of student roomers. ${ }^{420}$ In such an inquiry, the presentation of fact bases-in a coinprehensive plan or otherwise-would greatly aid a court's review.

\section{C. "Benign" Racial Zoning and Other Experiments.}

This article has alluded to the efforts of some inunicipalities durnig the early decades of this century to separate white residential neighborhoods from their black counterparts by means of segregation ordinances. ${ }^{421}$ Because these ineasures intended clearly discernible white and black residential areas they were often called "checker-board" or-

416. 131 N.J. Super. 29, 328 A.2d 242 (App. Div. 1974), rev'd on other grounds, 69 N.J. 67,350 A.2d 482 (1976).

417. 131 N.J. Super. at $31,33,328$ A.2d at $242,244$.

418. See City of Santa Barbara v. Adamson, 27 Cal. 3d 123, 610 P.2d 436, 164 Cal. Rptr. 539 (1980).

419. See State v. Baker, 81 N.J. 99, 114 n.10, 405 A.2d 368, 375 n.10 (1979).

420. See Kirsch Holding Co. v. Borough of Manasquan, 59 N.J. 241, 254, 281 A.2d 513, 520 (1971) (dictum) (traditional-family ordinance invalidated on the basis that it was too broad in its sweep, excluding land users who did not threaten to exhibit the undesirable behavior); Larson v. Mayor of Spring Lake Heights, 99 N.J. Super. 365, 374, 240 A.2d 31, 36 (Law Div. 1968) (municipaity should have enforced existing police power ordinances rather than enacting overbroad zoning ordinances).

421. See supra note 21 and accompanying text. 
dinances. In 1962 Professor Boris Bittker considered a hypothetical case in which the imaginary Town of New Harmony, Illinois, enacted a checker-board ordmance designating all residential lots within the municipahity alternately as "white" and "black."422 Only whites could acquire and occupy a "white" lot, and only blacks could hold an interest in the property beside it. The difference between this checker-board ordinance and those of an earker time was that New Harmony's neasure was intended to proniote racial integration, not segregation: New Harmony's ordimance posited that if whites and blacks were not legally coinpelled to live side by side, the two races would tend to live apart.

Shortly after Bittker created the "benevolent" checker-board ordinance, another commentator created a different hypothetical case, this time involving an "integration ordinance."423 In this hypothetical, the City of Bayside imposed on publicly assisted housing an occupancy ratio allotting seventy percent of the homes to whites and thirty percent to blacks. The ratio was imposed to avoid the "tipping point," the theoretical "point at which a rismg proportion of nonwhites will cause whites to abandon an area," 424 thereby thwarting the goal of racial integration.

The hypothetical Bayside ordinance, or soniething very inuch like it, was nearly adopted in Oak Park, Illinois, in 1973.425 The Oak Park ineasure proposed creatimg a racially integrated community. ${ }^{426}$ To this end, the amendinent to the municipality's Fair Housing Ordinance would have made it unlawful to sell any real estate in a designated area to a black person if thirty percent or more of the block, as defined in the regulation, was occupied by blacks. ${ }^{427}$ Furthermore, in multiple family dwellings of a certain size, the regulation would have made it

422. See Bittker, The Case of the Checker-Board Ordinance: An Experiment in Race Relations, 71 YALE L.J. 1387 (1962).

423. See Note, The Integration Ordinance: Honi Soit Qui Mal Y Pense, 17 StaN. L. Rev. 280 (1965).

424. Id. at 282 n.14.

425. See Note, The Use of Racial Housing Quotas to Achieve Integrated Communities: The Oak Park Approach, 6 LoY. U. CHI. L.J. 164 (1975). The nunicipality ultimately rejected the housing quota approach in favor of a more broad-ranging plan. Id. at 166. The Oak Park measure was not technically a zoning ordinance. See id. at 164 n.3. It did, however, designate permitted land uses and their locations and thus functioned as a zoning regulation.

426. See id. at 165 . Apparently blacks were moving into the eastern part of the municipality, and a possibility existed that, with white flight, the area would become entirely black. The proposed measure sought to avoid this result. Id. at 165 n.4.

427. The material provision read as follows:

24-1/2.10.3 Limitation on Sales in Designated Area. It shall be unlawful for any seller or any agent for any seller to knowimgly sell any real property to a black person on any block in the designated area if thirty $(30 \%)$ percent or more of the block betwecn two intersecting streets on both sides of the street has been occupied by black persons.

Quoted in id. at 164 n.3. 
unlawful to rent a unit to a black person if thirty percent or more of the units had been rented to blacks. ${ }^{428}$ The proposal charged the mumcipality's Community Relations Department with "locat[ing] comparable housing . . . in other areas of the Village of Oak Park" for any black person prevented froin buying or renting accommodations in the municipality because of the ainendment. 429

Racial quotas to achieve integration in housing have received wide attention in the professional literature. 430 Programs affirmatively seeking racial balance in housing through ceiling quotas, including integration ordinances, rely on the basic premise that integrated housing is good $^{431}$ and is legitimately pursued through quota schemes. This argunrent could distinguish integration ordinances from the segregation ordinance struck down im Buchanan v. Warley 432 or the raciallyrestrictive covenants that courts were prohibited froin enforcing in Shelley v. Kraemer ${ }^{433}$ because the ultimate goal of integration ordinances-integration and racial balance-is desirable, whereas the Buchanan and Shelley measures were aimed at preserving undesirable

428. The wording of this provision was as follows:

24-1/2.10.4 Rentals in Designated Area. It shall be unlawful for any owner or any agent for an owner to knowingly rent any apartment in a multiple family dwelling of four or more units in the designated area to a black person if $30 \%$ or nore of the multiple family dwellings in the building have been rented to or have been occupied by black persons.

This section shall not apply to the renewal of an existing lease.

Quoted in id. at 164 n.3.

429. Id. (quoting proposed ordinance).

430. See, e.g., Ackerman, Integration for Subsidized Housing and the Question of Racial Occupancy Controls, 26 STAN. L. REV. 245 (1974); Bittker, supra note 422; Hellerstein, The Benign Quota, Equal Protection, and "The Rule in Shelley's Case," 17 Rutgers L. Rev. 531 (1963); Kaplan, Equal Justice in an Unequal World: Equality for the Negro-The Problem of Special Treatment, 61 Nw. U.L. REv. 363 (1966); Navasky, The Benevolent Housing Quota, 6 How. L.J. 30 (1960); Developments in the Law-Equal Protection, 82 HARv. L. REv. 1065, 1104-32 (1969); Note, The Benign Housing Quota: A Legitimate Weapon to Fight White Flight and Resulting Segregated Communities?, 42 FORDHAM L. REv. 891 (1974) [hereinafter cited as Note, The Benign Housing Quota]; Note, supra note 425; Note, Racial and Ethnic Quotas: The Tipping Phenomenon in Otero v. New York City Housing Authority, 4 N.Y.U. Rev. L. \& Soc. ChANGE 1 (1974) [hereinafter cited as Note, Racial and Ethnic Quotas]; Note, supra note 423.

431. There is support for the view that integration in housing is in the public interest. See Linmark Assocs. v. Township of Willingboro, 431 U.S. 85, 94-95 (1977) ("This Court has expressly recognized that substantial benefits fiow to both whites and blacks froin interracial association and that Congress has nuade a strong national commitunent to promote integrated housing.") (citing Trafficante v. Metropolitan Life Ins. Co., 409 U.S. 205 (1972)); $c f$. Kaplan, supra note 430, at 389 n.54 ("One's advocacy of the benign quota is of course determined by the relative priority he gives to integration and to the benefit which will be denied those Negroes in excess of the quota."). Integration in housing may bring such benefits as integration in schools. See, e.g., G. MULler EXCLUSIONARY ZONING 12 (1972); Note, supra note 423, at 281. But housing integration inay also cause problems such as less pohtical power for the minority. See Kaplan, supra note 430 , at $397-98$.

432. 245 U.S. 60 (1917).

433. 334 U.S. 1 (1948). 
racial inequality. ${ }^{434}$ An argument of this type might well refute an attack alleging tliat an integration ordmance was not autliorized by the relevant enabling legislation. ${ }^{435}$ The typical enabling act authorizes the regulation of land use to promote the "general welfare"; the laudable goal of achieving integrated lousing seems to fall within the scope of this power.

The inevitable constitutional challenge would present a more difficult problem. Race has long been a suspect classification, ${ }^{436}$ and thus integration ordinances would receive strict scrutiny pursuant to the equal protection clause of the fourteenth amendment. Under such scrutiny the municipality would liave to demonstrate that the regulation furthered a compelling state interest and was the least restrictive method of accomplishing that goal:437 a difficult proposition given the uncertainty over the percentage of minority representation that will cause a dwelling district to "tip" toward segregation. ${ }^{438}$ Furthermore, integration ordinances generally involve "ceiling" rather than "access" quotas. Access quotas, such as the one considered in the Bakke case, 439 are supposedly "bemign" because they directly benefit a minority group with a history of societal discrimination. In contrast, a ceiling quota requires members of the disadvantaged minority to bear the burden of achieving integrated housing.440 "Indeed," write the authors of one commentary, "tlle opinions in Bakke suggest that the Court might not be sympathetic to the use of 'benign' ceiling quotas." 441

434. See Bittker, supra note 422, at 1392, 1393-95; Hellerstein, supra note 430, at 536-41. But cf. Note, supra note 425, at 168 (suggesting that Buchanan, Shelley and Reitman v. Mulkey, 387 U.S. 369 (1967), "indicate that the Court will invahdate actions by the state which inake racial distinctions the basis for access or non-access to housing").

435. See, e.g., State v. Wilson, 157 Fla. 342, 25 So. 2 d 860 (1946) (segregation ordmance); State v. Darnell, 166 N.C. 300,81 S.E. 338 (1914) (segretation ordmance).

436. See, e.g., Brown v. Board of Educ., 347 U.S. 483, 495 (1954); Korematsu v. United States, 323 U.S. 214, 216 (1944); Hirabayashi v. United States, 320 U.S. 81, 100 (1943).

437. Cf. Developments in the Law-Equal Protection, supra note 430, at 1106 ("The traditional standard of review of such classifications would require that the state demonstrate an overriding justification for the use of racial distinctions and show that the purpose of the action could not be accoinplished by a non-racially focused alternative.") (footnote omitted).

438. See Note, Racial and Ethnic Quotas, supra note 430, at 14; Note, Benign Quotas-Fair Housing-Affirmative Action Permits the Granting of Preference to Whites in Admission to Public Housing to Insure Racial Integration, 20 WAYNE L. REv. 1109, 1125-26 (1974).

439. Regents of the Univ. of Cal. v. Bakke, 438 U.S. 265 (1978), involvcd the validity of a quota system used to increase the number of minority students entering the University of California at Davis Medical School.

440. See Rubinowitz \& Trosman, Affirmative Action and the American Dream: Implementing Fair Housing Policies in Federal Homeownership Programs, 74 Nw. U.L. REv. 491, 565 (1979); Note, The Benign Housing Quota, supra note 430, at 900.

441. See Rubinowitz \& Trosman, supra note 440 , at 559 n.258. 
Obviously benign racial quotas of either type raise a multitude of difficult legal and social issues. To incorporate a quota scheme into a zoning ordmance, a local governing body would have to beheve in the value of integrated housing with sufficient fervor to accept the public criticism and legal attacks mevitably attending the adoption of such a measure. A desire to avoid such repercussions probably contributed to the Village of Oak Park's eventual retreat from its proposed integration ordinance. ${ }^{442}$ Nevertheless, the integration ordinance renraims a potential application of zoning for direct social control.

If a municipality adopted an mclusionary racial ordinance, it would be pursuing the wholly ideological objective of integration in housing. Clearly, the goals articulated during the period of the development of New York City's building zone resolution have given way to, or at least have been joined by, a plethora of more ideological objectives. This shift in objectives is particularly apparent in traditionalfamily ordinances and age-restrictive zoning. Some would argue that the ideological concerns furthered by these two exaniples of zoning for direct social control involve little inore than petty residential preferences not deserving of legislative recognition. But with inclusionary zoning and integration ordinances, zoning for direct social control seeks to further ideological goals that lie at the heart of the American value-system and that are vitally "involved in creating an environınent suitable for democratic living." 443

This article has not identified all the possible applications of zoning for direct social control. Other instances of this sort of land use regulation have already arisen and new inanifestations will continue to appear. An exainple appears in Robert Nelson's description of how the artists of SoHo, a neighborhood in New York City, preserved the character of their community. 444 In SoHo, artists have converted old manufacturing lofts to serve their needs. But a large number of relatively

442. Oak Park ultimately developed a wide-ranging community plan for racial integration with a number of alternatives to ceiling quotas. This integration plan is discussed in Note, supra note 425 , at 182-83. One of the more interesting proposals of the integration plan involved the adoption of an "equity assurance program": the inunicipabity would guarantee homeowners against any devaluation of their property below a certain proportion of appraised value. This assurance would help stabilize the occupancy of a neighborhood insofar as homeowners would no longer move because of a fear that integration would depress property values. See id. at 182 . The plan also called for a community-wide "orientation program" directed at all persons seeking housing in the community involving seminars, media advertising, and the nandatory distribution of printed material through the housing industry. "This orientation would be intended to inake the individual examine his own housing decision so that his selection might further the Village's goals." Id. at 183.

443. Williams, supra note 177 , at 319.

444. See R. Nelson, supra note 202, at 15. 
wealthy New Yorkers who evidently like to live among artists threatened to innundate the area. The resulting increase in rent levels would ultimately have forced out the legitimate artists. Not about to let SoHo go the way of Greenwich Village, the artists in 1971 "persuaded the New York City government to establish an Artists Certification Committee that would certify applicants as professional artists and then to make such certification a zoning requirement for SoHo residency." 445 This is a fascinating example of the importance the identity of land users may have in shaping the character of a neighborhood.

The City of Long Beach, New York, appeared concerned with the identity of certam land users for less praiseworthy reasons when, in 1973 , it adopted an ordimance annending its municipal code with respect to the operation and occupancy of hotels, boarding houses and rooming houses. A federal district court subsequently reviewing the ordinance noted that it dealt with, "[i]n substance, . . . the registration of the mentally ill." 446 Among other things, the ineasure provided that "[t]hose patients requiring continuous inedical or psychiatric services shall not be registered," and that "certain personal records shall be maimtamed for any person registered and remaining in excess of fifteen days." 447 Although the court found the ordinance unconstitutional, the case provides a striking example of how discerning a inunicipality may become in identifying land users in a local regulation. ${ }^{448}$

\section{Conclusion}

Zoning for direct social control represents a double departure from more traditional zoning efforts. First, such ordmances go beyond the mere governance of the physical aspects of the urban environinent and seek to regulate the users of land in residential districts. Second, not only do these ordinances frequently atteinpt to proinote more amorphous goals involving the preservation of cominunity character and aesthetics, but in inany instances they pursue ideological concerns. It is, mdeed, ironic that one commentator was noved to write as early as 1927, "the conclusion is forced upon us that the police power has been extended until the limits upon the power, as generally conceived, no

445. Id.

446. Stoner v. Miller, 377 F. Supp. 177, 178 (E.D.N.Y. 1974). Technically speaking, the ordinance was not a zoning measure but, rather, a hotel and boarding house regulation. However, in identifying certain persons and restricting their use of specified dwelling types, the ordinance bore a close resemblance to zoning for direct social control.

447. Id.

448. The court held that the ordinance both infringed on the fundamental rights of travel and privacy and was overly vague. See id. at 180-81. 
longer exist."449 Particularly with respect to zoning for direct social control, this assertion overstates the case today. Clearly the federal and state constitutions continue to impose limitations, even if constitutional guarantees adjust to new public needs. 450 The statutes that delegate zoning power to the municipalities from the state legislatures are also a restraining influence. Determining how these various limitations should be applied to ensure that zoning for direct social control does not become abusive but remams sensitive to the competing values involved poses a difficult problem.

Whenever land use is regulated, important interests clash: "protection of the mdividual confronts utilitarian goals of provision for the general welfare."451 There is, moreover, the interest of a municipality in determining its own destiny. In the landmark zoning case of Village of Euclid v. Ambler Realty Co. ${ }^{452}$ the Supreine Court noted that a separate inunicipahty has the "authority to govern itself as it sees fit." 453 In Village of Belle Terre v. Boraas, 454 the Court reaffirmed that a con1munity has a "right to define its own character and values."45s There are several reasons why municipalities should retam a good deal of 1ocal autonomy. For one thing, the affection for local democracy at a "grass roots" level is deeply embedded in American political ideology. 456 It is often said that local decisionmaking is more responsive to local needs, ${ }^{457}$ and that government at the local level provides greater public access to government, affording an opportunity for mcreased citizen participation. ${ }^{458}$ Furthermore, local autonomy permits local gov-

449. N. BAKER, LeGal Aspects OF ZoNing 26 (1927).

450. See E. Freund, supra note 104, \$21; A. Bettman, Is Housing A Public Use?, in City and Regional Planning PaPers, supra note 99, at 87; Cromwell v. Ferrier, 19 N.Y.2d 263, 26869, 225 N.E.2d 749, 752, 279 N.Y.S.2d 22, 26 (1967).

451. J. Dimento, The Consistency Doctrine and the Limits of Planning at xv (1980).

452. 272 U.S. 365 (1926).

453. Id. at 389 .

454. 416 U.S. 1 (1974).

455. See Developments in the Law-Section 1983 and Federalism, 90 HARv. L. REv. 1133, 1180 (1977); $\mathscr{c f}$. Lupu, supra note 192, at 1053 ("[1]t has been a constant tenet of American constitutional tradition that, outside the realms of thought, expression, religion and conscience, the political agencies of the community may define the limits of acceptable hunan enterprise. Belle Terre is consistent with that tradition.") (footnote omitted).

456. See, eg., Sandalow, supra note 334, at 709-10; Silverman, Housing for All Under Law: The Limits of Legalist Reform,.27 U.C.L.A. L. REv. 99, 144 (1979).

457. See, e.g., Sandalow, supra note 334, at 710; Developments in the Law-Section 1983 and Federalism, supra note 455, at 1180; Note, Land Use Regulation, the Federal Courts, and the Abstention Doctrine, 89 YALE L.J. 1134, 1141 (1980) [hereinafter cited as Note, Land Use Regulation]; Note, The Constitutionality of Local Zoning, 79 YALE L.J. 896, 900 (1970).

458. See supra authorities cited in note $457 ; c f .1 \mathrm{~J}$. METZENBAUM, THE LAW OF ZoNing at $v$ (2d ed. 1955): 
ernments to act as laboratories for experimentation in social policy. 459 The ability of localities to develop policies responsive to their own unique needs has the beneficial result of promoting diversity. ${ }^{460}$ Ultimately, individuals have a greater opportunity to cloose a community particularly suited to their personal needs and preferences when local governments can formulate imdependent policy responses to commumity issues. ${ }^{461}$ For example, local age-restrictive land use controls provide a citizen with the choice of living in an age-integrated or an agehomogeneous environment, a choice that might not otherwise be available. 462

There are also persuasive counterarguments. Largely because of the smaller unit of government involved, the political process in local decisionmaking may be inferior to the political processes at the state or federal levels. ${ }^{463}$ This observation ecloes the argument of Federalist $X$ : a smaller society is more likely to have a homogeneous population with a clearly identifiable majority and, with fewer imterests being brought to bear on a given issue, it is inore likely that the majority will successfully disregard the interests of the minority. ${ }^{464}$ In addition, local gov-

\footnotetext{
It [zoning] has helped to restore the original concept of the American form of governinent-the Town Meeting theory-for, unlike changes im the average law which are voted by those in authority with no specific notice to those affected, zoning changes may not-generally - be made without actual or constructive notice to all those affected within the neighborhood, with an opportunity to be heard.
}

459. See, e.g., Sandalow, supra note 334, at 719; Developments in the Law-Section 1983 and Federalism, supra note 455, at 1180; Note, Land Use Regulation, supra note 457, at 1141. In this regard, Professor Tribe has pointed out that traditional-family ordinances might be viewed as courageous social experiments in light of the increasing prevalence of alternative domestic associations. See L. TRIBE, supra note 171, at 989.

460. See Note, The Constitutionality of Local Zoning, supra note 457, at 900 ("A significant benefit derived froun local responsiveness and flexibility is diversity."); Developments in the LawSection 1983 and Federalism, supra note 455, at 1180:

This conception of political decentralization as the key to the preservation of diversity and of government attuned to local values and probleins has been considered particularly compelling in the United States, given the political and cultural heterogeneity of the American people and the traditional focus on the community as the center of political and social life.

461. See Note, The Constitutionality of Local Zoning, supra note 457, at 900 ("Many decisions have primarily local significance, yet must be inade by all communities. Giving eacl community power to order its own consumption cloices from the common menu not only encourages innovation and experimentation, but also allows individuals a greater opportunity to satisfy their own preferences."). Specialization among municipalities may enhance economic efficiency as well. See R. Ellickson \& A.D. TARLoCK, supra note 53, at 811-13 (discussion of Tiebout Hypothesis).

462. See Travalio, supra note 123 , at $319-20$.

463. See Bruff, supra note 334, at 671-72; Sandalow, supra note 334, at 710-12; Note, Land Use Regulation, supra note 457, at 1151-52.

464. See The FedERAlist No.10, at 83 (J. Madison) (New Am. Lib. ed. 1961), quoted in Bruff, supra note 334, at 672.

The smaller the society, the fewer probably will be the distinct parties and interests composing it; the fewer the distinct parties and interests, the more frequently will a inajority be found of the same party; and the smaller the number of individuals coinposing 
ernmental structure lacks "complicated checks and balances" and "clear structural separations of power," perhaps creating a greater risk of abusive action. ${ }^{465}$ The possibility that municipal actions will have extraterritorial effects and the inadequacy of procedural safeguards have also been cited as justifications for judicial supervision of local actions. ${ }^{466}$ Finally, local land use decisionmakers may be less informed than those at the state level. 467

Factors unrelated to local competence also dictate in favor of a more circuinspect use of zoning for direct social control. Such zoning could seriously interfere with the interest individuals have in living with domestic associates of their own choosing. For example, in Belle Terre the village's zoning ordmance recognized the interest of traditional families in associating with their own kind and thus, conceptually speaking, their personal interest was in harmony with the value of local autonomy. In contrast, the village's ordinance did not recognize and, in fact, interfered with the associational interests of the six unrelated university students who wished to he together in the village. 468 Moreover, the values enibodied in a particular zoning ordinance exercismg direct social control niay compete with the desirable goal of affording all sectors of the population a reasonable opportunity to obtam housing in the area. An ordmance authorizing a retirement community, for instance, might contribute to the exclusion of low- and noderate-inconie familes with children from the municipality.

This article has discussed these conipeting values. How should a reviewing court deal with then in a sensitive nıanner when the validity of a direct social control zoning ordinance is challenged? A rather energetic, but not prohibitive form of judicial review is probably appropriate. Zoning of this type represents a novel use of local power and,

a majority, and the smaller the compass within which they are placed, the more easily will they concert and execute their plans of oppression.

Cf. Makielski, Zoning: Legal Theory and Political Practice, 45 J. URB. L. 1, 22 (1967) (The zoning system "has the effect of reinforcing and protecting middle-class economic and social values while providing hittle or no opportunity for underrepresented groups to find expression or recognition.").

465. See Bruff, supra note 334, at 672-73.

466. See id. at $671,673$.

467. See Note, Land Use Regulation, supra note 457, at 1151.

468. These interests, although similar, were competing. See City of Chula Vista v. Pagard, 115 Cal. App. 3d 785, 796, 171 Cal. Rptr. 738, 743 (1981) (discussion of competing rights of privacy); $c f . L$. TRIBE, supra note 171, at 977 (1978) ("Two claims of association are at stake [in Belle Terre]-that of the students, wishing to hve with one another in their preferred way in the village, and that of the great majority of the village's inhabitants, wishing to preserve the integrity of their preferred associational form as a community of traditional families") (footnote omitted); Michelman, supra note 144, at 196-97 (discussion of "community-self-determination type of pubhic-interest model of legitimacy"). Belle Terre's mayor claimed that with its opinion the Supreme Court recognized a "community's right to privacy." M. DANIELSON, supra note 12, at 183-84. 
because it identifies land users, may be particularly subject to prejudicial manipulation. ${ }^{469}$ This article has suggested several means of review that would prevent abuses yet provide municipalities with substantial leeway to experiment. Fact bases tests, comprehensive plan requirements, the availability of alternative housing sites, and the adjustment of the presumption of validity and burdens of proof are all possible tools. By appropriate use of one or more of these tools, the responsibility for planning policy can remaim with local governments to a larger degree than would be possible under more rigorous forms of substantive review.

In accordance with these principles, for example, a court would probably not hold on the basis of Moore 470 that age-restrictive zoning is unconstitutional as applied to the elderly excluded from a retirement community because of the youth of one or more of the members of their family. 471 Within the confines of the facts, a court could emphasize the limited geographic scope of the retirement community and poimt to reasonably comparable housing alternatives in the municipality in rejecting the claim. By way of further illustration, a court could uphold a traditional-family ordinance, although perhaps not so readily as some courts have in the past, if suitable alternative housing existed for so-called "voluntary" families and if the municipality could articulate its goals and perhaps come forward with some empirical basis for passing such an ordmance. In any event, if a reviewing court must overturn a traditional-family ordmance, it should strive to do so on the grounds that the statutory mandate has been exceeded, not on the grounds that a constitutional guarantee has been violated.

Zoning for direct social control is a recent and growing innovation. Courts will no doubt be mcreasingly called on to draw the line between reasonable and unfair restrictions of this sort. This article has suggested the attitude with which courts might properly approach zoning for direct social control. By and large, no attempt has been made to pass judgment categorically on the appropriateness of any particular instance of this type of zoning. Such a judgment would ignore the flexible attitude advocated, whereby such zoning ordmances receive enough deference that, given reasonably supportive factual circumstances, many of them can be allowed to stand. This approach respects the coinpeting values often presented by zoning for direct social con-

469. Cf. Bruff, supra note 334, at 688 ("There is reason for greater caution, however, in upholding local assertion of powers that are novel or that, however exercised, have a special capacity for abuse.") (footnotes omitted); see also id. at 701.

470. Moore v. City of E. Cleveland, 431 U.S. 494 (1977) (plurahity).

471. But see Doyle, supra note 184 , at $89-97$. 
trol. The devices and concepts accompanymg this approach could aid courts in setting a steady course between judicial activisin and judicial self-restraimt. 
.

. 